\title{
ANALYSIS OF SPACE HEATING AND DOMESTIC HOT WATER SYSTEMS FOR ENERGY-EFFICIENT RESIDENTIAL BUILDINGS
}

Gerald Dennehy

April 1983

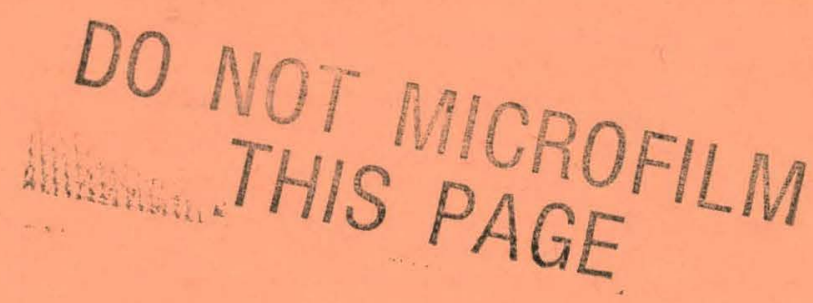

Prepared for the

ENERGY CONVERSION EQUIPMENT BRANCH

BUILDING EQUIPMENT DIVISION

UNITED STATES DEPARTMENT OF ENERGY

DEPARTMENT OF APPLIED SCIENCE

BROOKHAVEN NATIONAL LABORATORY

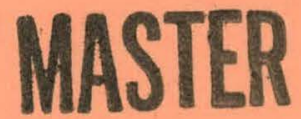
UPTON, LONG ISLAND, NEW YORK 11973 


\section{DISCLAIMER}

This report was prepared as an account of work sponsored by an agency of the United States Government. Neither the United States Government nor any agency Thereof, nor any of their employees, makes any warranty, express or implied, or assumes any legal liability or responsibility for the accuracy, completeness, or usefulness of any information, apparatus, product, or process disclosed, or represents that its use would not infringe privately owned rights. Reference herein to any specific commercial product, process, or service by trade name, trademark, manufacturer, or otherwise does not necessarily constitute or imply its endorsement, recommendation, or favoring by the United States Government or any agency thereof. The views and opinions of authors expressed herein do not necessarily state or reflect those of the United States Government or any agency thereof. 


\section{DISCLAIMER}

Portions of this document may be illegible in electronic image products. Images are produced from the best available original document. 


\section{The following pages are an exact representation of what is in the original document folder.}


This report was prepared as an account of work sponsored by an agency of the United States Government. Neither the United States Government nor any agency thereof, nor any of their employees, makes any warranty, express or implied, or assumes any legal liability or responsibility for the accuracy, completeness, or usefulness of any information, apparatus, product, or process disclosed, or represents that its use would not infringe privately owned rights. Reference herein to any specific commercial product, process, or service by trade name, trademark, manufacturer, or otherwise does not necessarily constitute or imply its endorsement, recommendation, or favoring by the United States Government or any agency thereof. The views and opinions of authors expressed herein do not necessarily state or reflect those of the United States Government or any agency thereof.
BNL 51698

UC-950

[Energy Conservation - Buildings and Community Systems (TIC-4500)

Gerald Dennehy

April 1983

\title{
ANALYSIS OF SPACE HEATING AND DOMESTIC HOT WATER SYSTEMS FOR ENERGY-EFFICIENT RESIDENTIAL BUILDINGS
}

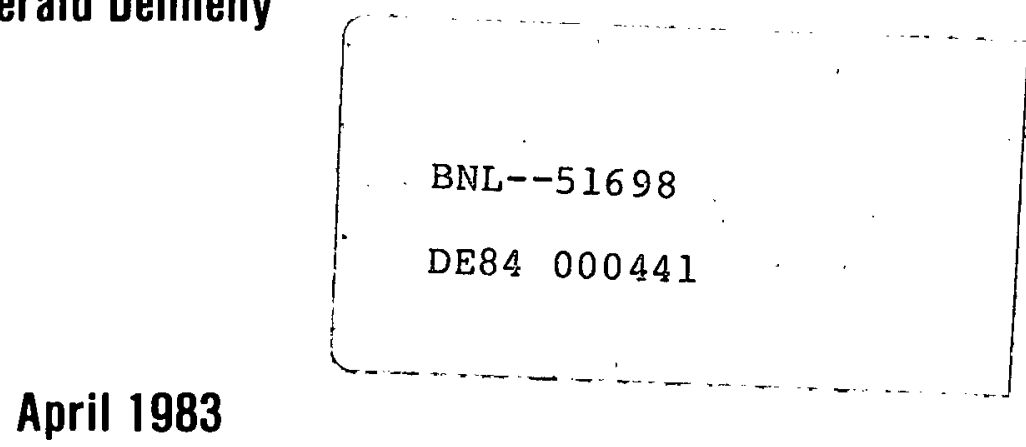

Prepared for the

ENERGY COVERSION EQUIPMENT BRANCH BUILDING EQUIPMENT DIVISION UNITED STATES DEPARTMENT OF ENERGY

\author{
DEPARTMENT OF APPLIED SCIENCE \\ BROOKHAVEN NATIONAL LABORATORY \\ ASSOCIATED UNIVERSITIES, INC.
}




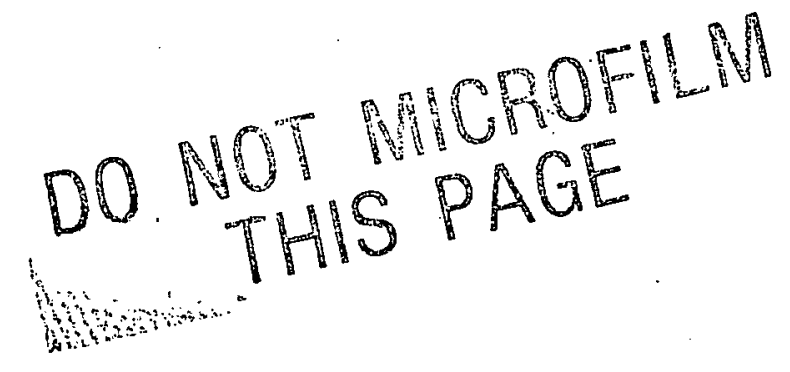

DISCLAIMER

This report was prepared as an account of work sponsored by an agency of the United States Government. Neither the United States Government nor any agency thereol, thu any of their employees, noor any of their contractors, subcontractors, or their employees, makes any warranty, express or implied, or assumes any legal liability or responsibility for the accuracy, completeness, or usefulness of any information, apparatus, product, or process disclosed, or represents that its use would not infringe privately owned rights. Reference herein to any specific commercial product, process, or service by trade name, trademark, manufacturer, or

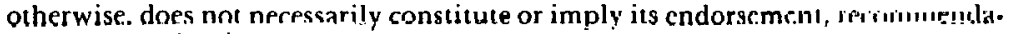
tIon, or favoring by the United States Government or any agenry, contractor or subcontractor thereof. The views and opinions of authors expressed herein do not necessarily state or reflect those of the United States Government or any agenry, contractor or subcontractor thereof.

Printed in the United States of America

Available Irom

National Technical Information Service

U.S. Department of Commerce

5285 Port Royal Road

Springfield, VA 22161

NTIS price codes:

Printed Copy: A05; Microfiche Copy: A01 
This report provides an analysis of the best ways of meeting the spaceheating and domestic-hot-water (DHW) needs of new energy-efficient houses with very low requirements for space heat. The DHW load is about equal to the space-heating load in such houses in northern climates. The equipment options which should be considered are discussed, including new equipment recently introduced in the market. It is concluded that the first consideration in selecting systems for energy-efficient houses should be identification of the air-moving needs of the house for heat distribution, heat storage, ventilation, and ventilative cooling. This is followed, in order, by selection of the most-appropriate distribution system, the heating appliances and controls, and the preferred energy source, gas, oil, or electricity. 
List of Tables

vii

List of Figures

I. INTRODUCTION

II. TRENDS IN BUILDING DESIGN

A. Envelope Heat Losses 3

B. Air Infiltration . 3

C. Passive Solar Gain 3

D. Thermal Storage . . 4

E. Floor Space and Plan 4

F. Increased Emphasis on Zoning 5

G. Need for Energy Flow Controls 6

III. SPACE HEATING ENERGY REQUIREMENTS 9

A. Design Heat Load 9

B. Seasonal Heating Requirements 13

C. Space Heating Energy Costs 14

IV. DOMESTIC HOT WATER ENERGY REQUIREMENTS 21

A. Hot Water Use 21

B. Energy Costs 21

V. EQUIPMENT OPTIONS AVAILABLE TO HOME DESIGNERS 25

A. Space Heating 25

1. Central Furnaces and Boilers 25

2. Heat Pumps 30

3. Electric Resistance Baseboard Heaters 30

4. Electric Kadiant Fanels 31

5. Electric Storage Heaters 31

6. Vented Gas-Fired Room Heaters 31

7. Fuel Use and System Characteristics in Existing Housing 32

B. Domestic Hot Water Heating $\quad 34$

1. Introduction 34

2. Gas-Fired Storage Water Heaters $\quad 37$

3. Oil-Fired Storage Water Heaters 38

4. Electric Storage Water Heaters 38

5. Instantaneous Water Heaters 38

6. Heat Pump Water Heaters 39

7. Solar Water Heating 41

C. Integrated Space Heating and Domestic Hot Water Systems 41 
TABLE OF CONTENTS (CONT'D)

Page

VI. SYSTEMS SELECTION

A. Introduction

B. Space Heating

1. Air Moving Needs

2. Distribution System Requirements

51

3. Heating Equipment Selection

C. Dumeslic Hul Waler Healling

2/

D. Price Projections for Fuels and Electricity

VII. SUMMARY AND CONCLUSIONS 
1. Comparative Building Heating Loads for 1500 Square Foot Single Story Houses with Four Levels of Envelope Thermal

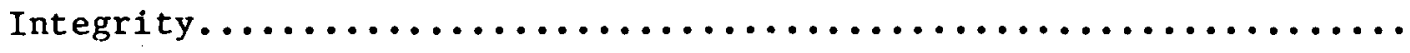

2. Design Heating Loads at $68^{\circ} \mathrm{F}$ Inside Temperature.............. 12

3. Annual Auxiliary Heat Requirements of 1500 Square Foot Houses..... 15

4. Annual Auxiliary Heat Requirements of Single Family Houses per 1000 Square Foot of Floor Space......................... 16

5. Heating Energy Prices and Costs, $1980 \ldots \ldots \ldots \ldots \ldots \ldots \ldots \ldots \ldots \ldots \ldots$

6. Approximate Annual Heating Costs Per 1000 Square Feet of Floor Space $(1980$ Energy Prices) .............................. 19

7. Hot Water Use in Single Family Residences.................. 21

8. Annual Operating Cost of Domestic Hot Water Heaters Derived from 0 RNL Study.................................. 23

9. Fuel Use and Heating System Characteristics by Census

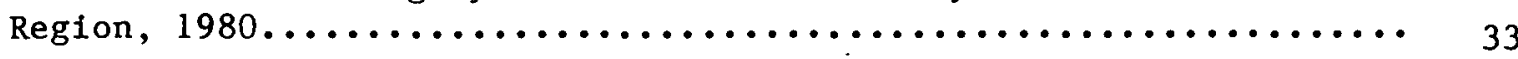

10. Availability of Natural Gas to Households, $1981 \ldots \ldots \ldots \ldots \ldots \ldots \ldots . . \ldots 5$

11. Water Heating Fuel Use Characteristics by Census Region......... 36

12. Classification of Integrated Space Heating and Domestic Hot Water Systems................................. 42

13. Average Residential Energy Prices (Midprice Scenario).......... 60

14. Regional Composite Price Projections for Natural Gas............ 61

15. Projected 1990 Space Heating Costs per Million Btu of Heat

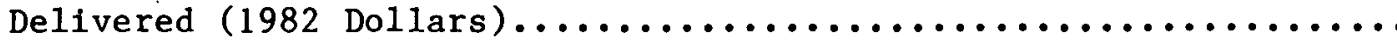




\section{LIST OF FIGURES}

Figure

1. Energy Flows in Residential Buildings..................... 7

2. Single Story Houses with Four Levels of Envelope Thermal Integrity... 10

3. Ranges of Annual Energy Cost for Space Heating and DHW for Various Building Designs and Locations (1980-1981 Energy Prices)......... 24

4. AFUE Distribution for all Gas and 011 Furnaces and Boilers with

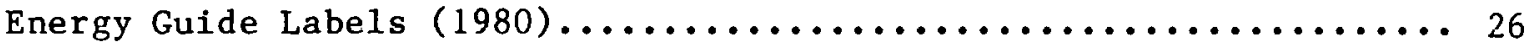

5. Part Load Efficiency of Residential Furnaces................ 28

6. Part Load Efficiency of Oil-Fired Residential Boilers........... 28

7. U.S. Census Regions and Divisions...................... 35

8. Air Flow Required to 'Iransport Thermal Energy................48

9. Power Required to Drive a Fan......................... 48

10. Auxiliary Heating and Cooling Requirements of Building C........ 50

11. Forced Air Heating System with Ventilating Capability.......... 53

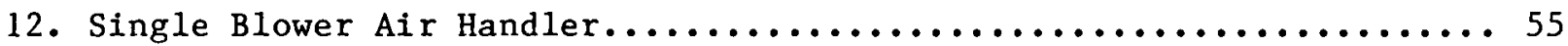

13. Acorn Structures, Inc. Isolated Sunspace House............... 55

14. DOE/EIA World 0il Price Projections..................... 59

15. DOE/EIA Natural Gas Price Projections (U.S. Average Price, Midprice Scenario)................................ 59

16. Average Residential Energy Prices (Midprice Scenario)...........6 60 


\section{INTRODUCTION}

The energy efficiency of most conventional new homes has improved significantly since 1973, when the oil embargo set off a dramatic rise in the price of all forms of energy. In the same perfod, several new types of energy-efficient houses have become increasingly popular, including passive solar, double-envelope, and superinsulated types. These houses have low heat losses and usually receive some heat in the form of solar radiation. Therefore, they have a significantly lower requirement for heat from whatever space heating equipment is installed. Their need for domestic hot water (DHW), however, is about the same as for older homes. As a consequence, the DHW load, which has usually been only about a third of the space heat load in northern climates, often becomes the dominant load in such houses.

The purpose of this report is to identify the mechanical equipment options that are available for new energy-efficient housing and to develop an approach to the selection of systems and equipment to meet their space heating and cooling and DHW requirements. In the organization of the report, consideration is given first to trends in building design. This is followed by an analysis of the space heating requirements of four types of houses in six geographical locations, their DHW requirements, and the energy costs of satisfying the needs using various fuels, at current prices. A discussion is then provided of the many system and equipment options available for supplying space heating and $\mathrm{DHW}$ heating, including equipment recently introduced in the market. The next section discusses the important factors to be considered in selecting the best systems for a particular house and also the projected future prices for natural gas, fuel oil and electricity, and describes a recommended approach to making the selection. The final section provides a brief summary of the prior sections and conclusions.

In the sections of this report which describe the system and equipment options available for space heating and DHW heating and the recommended approach to system selection, specific products and manufacturers are identified, as examples. Product descriptions, performance claims and data are based on information supplied by the manufacturers. No claims are made concerning the validity or completeness of any product descriptions. The mention of certain company names or brand-name products is not intended as a recommendation of them over other companies or similar products on the market. Before purchasing or ordering any materials, it is sound practice to contact the manufacturer directly (or appropriate distributors and retailers) for complete information regarding a proposed application. Inclusion in this document does

not constitute endorsement by Brookhaven National Laboratory, Associated Universities, Inc., or the U.S. Department of Energy. 


\section{TRENDS IN BUILDING DESIGN}

\section{A. Envelope Heat Losses}

The best current building practices for conventional homes result in significant reduction in the "design heat load," which is the amount of heat lost from the house under worst case winter conditions in the area in which the house is to be built. The current practice involves increasing the levels of ceiling, wall and floor insulation and installing multiple window glazing and insulated doors. Ceiling insulation is increased to a maximum of $\mathrm{R}-38$ from average current building practice of $\mathrm{R}-19$ in most parts of the country. Wall insulation is increased from $R-11$ to $R-19$ and, in the coldest climates, to $\mathrm{R}-25$. Floor insulation of $\mathrm{R}-11$ and $\mathrm{R}-19$ is often considered. Double and triple glazing of windows is included. 1

\section{B. Air Infiltration}

The uncontrolled leakage of outside air into a house represents an additional envelope heat loss. It can account for one-third to one-half of the heat losses from the house. Good building practice is giving increased attention to controlling infiltration. This includes plugging holes and cracks, weather-stripping, and use of plastic sheeting instead of paper or foil insulation backing to provide a vapor barrier.

The average rate of infiltration of air into existing houses is believed to be equivalent to about one complete air change per hour (ACH). Leaky houses can easily have $11 / 2 \mathrm{ACH}$ and tight houses as little as $1 / 2 \mathrm{ACH}$. Some new energy-efficient houses, particularly superinsulated houses, have even less than $1 / 2 \mathrm{ACH}$. At infiltration levels below $1 / 2 \mathrm{ACH}$, there is concern about the concentration of indoor air pollutants from a variety of sources. Air-to-air heat exchangers are often used in very tight houses to maintair an acceptable level of ventilation without too much heat loss. These devices preheat cold air drawn in by a fan by transferring heat from a like amount of outgoing air in a suitable heat exchanger. They are being installed in increasing numbers in new houses in this country. 2

The superinsulated house is now generally defined as one having forced ventilation with an air-to-air heat exchanger along with a high level of insulation, an air-tight vapor barrier, and windows oriented for passive solar $\operatorname{gain}$. $^{3}$

\section{Passive Solar Gain}

A house with passive solar features is one which captures thermal energy from the sun by natural means, that is by radiation, conduction, and natural convection. Passive systems are distinguished from active systems by the absence of a mechanical pump or fan needed to force the flow of a heat exchange fluid. In most, but not all, cases a passive system is intimately integrated into the architecture of the building. Often, the materials of the building serve a dual purpose. For example, a window oriented to the south serves to collect the sun's heat and also provides both visual access to the outside and 
natural daylighting. Also, the walls of the building of ten serve for both thermal storage and structural support. ${ }^{4}$ A Washington, DC architect, Robert L. Miller, ${ }^{5}$ recently wrote: "Experiments in passive solar design (have) proved that the solar house could be as much as anything a rediscovery of traditional regional architecture, with its ancient and ingenious ways of modifying climate."

Hybrid solar houses are generally defined as those with passive solar features with fans added to improve the distribution of air. The fans move air from areas where solar energy is collected to cooler parts of the house or to storage, eliminate temperature stratification in the house, or perform all of these functions. In addition, they can contribute to cooling of the house when cooling is required.

The double-envelope house is usually one with an inner and outer roof, two walls on the north side, an attached sunspace on the south side, and a crawl space below the basement. Both shells are insulated. There is a considerable amount of passive solar gain in the sunspace. Alr is suppused to flow through the spaces between the walls in what has been called a "convective loop." These houses, like superinsulated houses, appear to require very little aux1liary heat. In our experience, however, the good performance is due more to the excellent insulative value of the double shell than to any effects of heat storage associated with air circulation in the between-shells space, $6,7,8$

There are now hybrid versions of double-envelope houses. The double-envelope is applied to only parts of the house, the remaining walls are heavily insulated, and fans or blowers are introduced to move warm air from the peak of the sunspace to storage. There is evidence that these designs, which combine the best features of superinsulation and the double envelope, are being perceived as an attractive option in the field of new energy-efficient house degign. 9,10

Passive solar gain is being designed into houses at an increasing rate. At a groundbreaking ceremony at Brookhaven National Laboratory for the Brookhaven House in Apr11, 1980, Thomas Stelson, DOE's Assistant Secretary for Conservation and Solar Energy, remarked "Passive solar energy has reached the point where anyone with good knowledge of the subject wouldn't build without 1t." 11

\section{Thermal storage}

Houses with passive solar features require some provision for thermal storage to prevent overheating during sunny days and to store excess heat for use at night. The simplest form of thermal mass is an unobstructed floor or wall located in direct sunlight. Water in cylindrical plastic otorage tubes is also used in some houses when it is acceptable to owners and builders. Modular water storage products are under development for installation in the structure of wood frame houses. Phase change materials--chemical salts that absorb heat when they melt and release 1t as they solidify--provide a much greater storage capacity. than masonry or water. They are also starting to become avallable in modular form. 
Hybrid solar houses--those equipped with fans--can store heat in chimney passages, in the core passages of concrete biocks, in rockbeds, or simply in exposed surfaces of the house and/or the basement or crawl space.

The type of thermal storage provided in the house and the way in which it is intended to function in meeting heating needs must be considered and evaluated in selecting the type of auxiliary heating system that is best for the house.

\section{E. Floor Space and Plan}

The median size of new single-family houses sold in the United States rose from about 1,560 square feet of floor space in 1974-1975 to 1,650 square feet in 1978-1979. It then fell back to 1,560 square feet in 1981.12 This reduction in median size is believed to be due to high interest and construction costs and also to a general trend toward fewer persons per household, which dropped from 3.11 in 1970 to 2.75 in 1980 , according to the census bureau. This is due to larger numbers of people living alone and fewer children per family. A study of 14,000 home buyers conducted in 1981 by the U.S. League of Savings Associations showed that almost 30 percent of home buyers were single and that more than 57 percent of homes bought went to small households with only one or two members.13 According to projections by the Joint Center for Urban Studies of MIT and Harvard, as reported by the National Association of Home Builders, almost two-thirds of the projected total number of 1990 households will be without children. 14 size reduction is of ten accompanied by improved interior space planning and more use of open plans with fewer dividers between rooms. These trends, particularly the one to more use of open plans, affect the selection of the most appropriate heating system and air distribution system for the house.

\section{F. Increased Emphasis on Zoning}

Increasing interest is being displayed in selective heating of rooms or areas of existing homes. High heating fuel bills, changing demographics and the changing composition of households have resulted in adoption of strategies for local area heating and cooling, i.e., conditioning of only those spaces that are occupied at a given time. Other spaces are allowed to float to levels outside the comfort zone. The acceptance of this strategy is demonstrated by the recent ctrong market interest in room-sized kerosene space heaters and electric radiant heaters, and the widespread use in some parts of the country of wood stoves.

New houses should be designed to permit convenient use of some type of local heating strategy, at the discretion of the occupants. Since the overall heating needs of new energy-efficient houses are less (much less, in some cases) than those of the existing hnusing stock, the potential for energy and cost savings from area heating will be diminished. It is nevertheless important to consider the optinns that exist. Area heating and cooling, or zone control, can provide an improvement in perceived comfort which occupants will find of benefit beyond the benefit of the energy actually conserved. 
Houses designed for a significant amount of passive solar heating tend to have uneven temperatures in the living space. Experience has shown that good zone control is essential in passive solar buildings. 15

\section{G. Need for Energy Flow Controls}

All houses require some means of moving heat energy into or out of the house, or between spaces in the house, both on a daily basis and a seasonal basis. The control of these energy flows includes such simple techniques as manual opening or closing of windows, opening or closing drapes or blinds, operation of exhaust fans, and thermostatically controlled on-off operation of the furnace blower.

In energy-efficient houses, particularly those designed to capture more passive solar energy than the amount ordinarily received hy conventional south-facing windows, the need for control becomes greater. The term energy flow controls has been applied to devires and systems for uoc in directing tle flow of air and heat for operation nf a house in a manncr which pluvides acceptable levels of comfort and lowest use of purchased energy for heating and cooling. 16 The arrows in Figure 1 show the types of energy flow that can exist in a house and the range of possible needs for energy flow controls at various locations.

The building designer is faced by a challenge of how to provide the required energy flow controls. Some of the controls can be provided by carefiul design wh1ch results in natural self-control without resort to any mechanical equipment. An example is the simple unvented Trombe wall. Heat is captured from the sun in a glass-covered masonry wall in the morning hours, stored in the mass of the wall, and released to the interior later in the day when the heat is needed to maintain a comfortable indoor temperature. The wall system can be designed for the optimal time lag between heat capture and heat release, usually above five hours, by varying the wall thickness and materials of construction,

While designing the house for as much natural eelf-control as is wasun ably possible is a good objective, it will usually be necessary to provide some mechanical systems to control energy flows in most energy-efficient houses. If even a moderate amount of passive solar heating is provided, some rooms are likely to overheat at times, even in the winter. A system is needed to direct heat. from the collection area to the occupied space or to storage, or both, depending on the needs of the house. The storage medium may be nothing more than certain structural parts of the building, such as cored passages in a chimney or floor. There is also a need for means to move heat from the occupied space to storage at times, and to move it in the opposite direction at other times. There is a need to control the flow of lieut from a central heating system, such as a furnace or boiler, to the occupled space. Moving heat from a furnace to storage might even be effective in some cases. Cooling of the house with a whole house fan, which can be very effective, requires air movers and some form of control. And if an air-to-air heat exchanger is installed to maintain satisfactory air quality in a very tight house, its air flows must be controlled in some manner. 


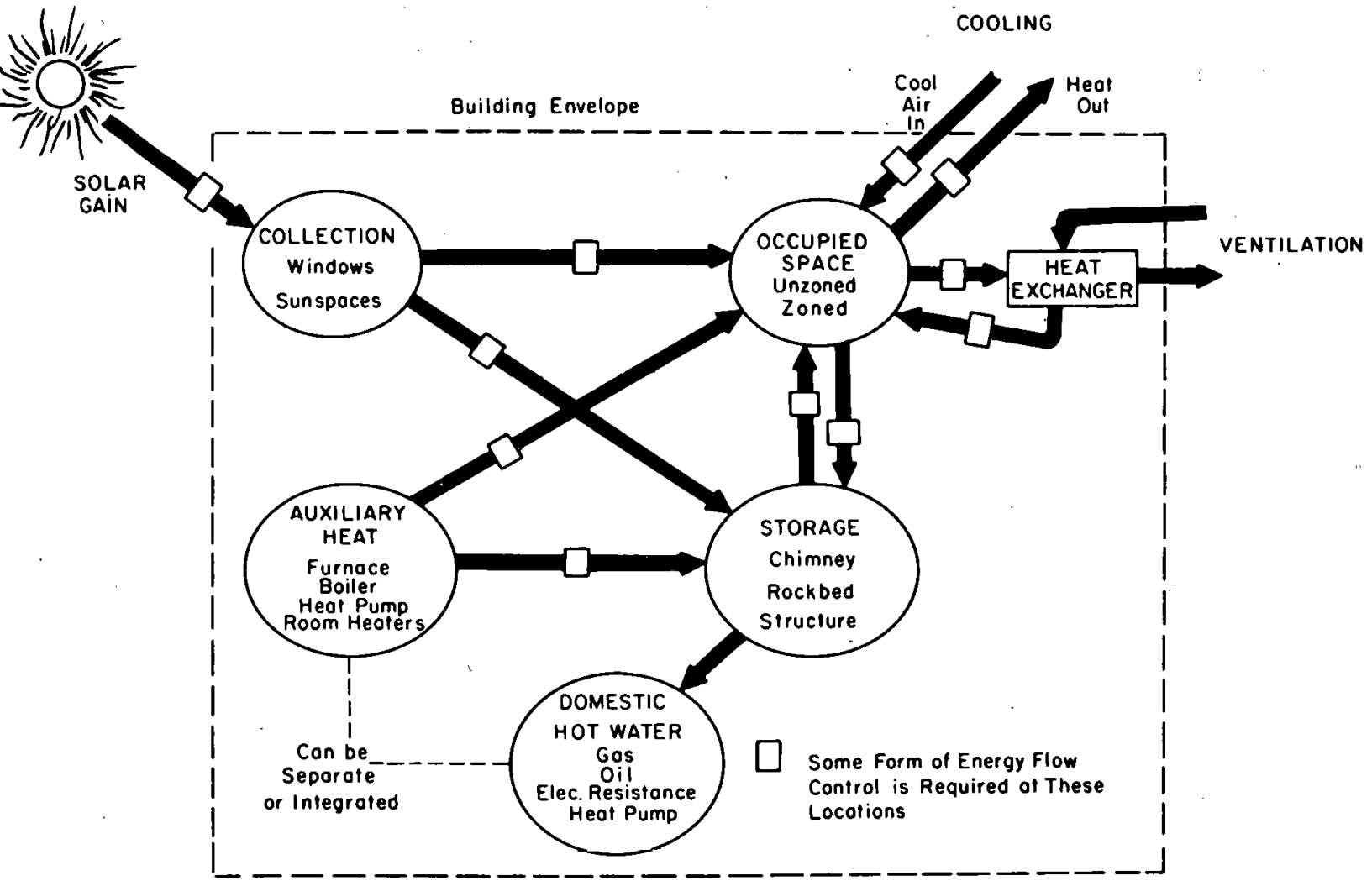

Figure 1. Energy Flows in Residential Buildings. 
THIS PAGE

\section{WAS INTENTIONALLY LEFT BLANK}




\section{SPACE HEATING ENERGY REQUIREMENTS}

\section{A, Design Heat Load}

The heat losses of individual houses vary great1y, depending on construction features such as amount and type of insulation, insulative value of windows and doors, and amount of leakage of air through the building envelope. The variation can be appreciated by considering four hypothetical homes with progressively reduced heat losses, as illustrated in Figure 2.

Building A in Figure 2 represents poor building practice of the type usually found in houses built just before World War II. Building B is typical of good practice used for tract houses in 1975, after the oil embargo. Building $\mathrm{C}$ is typical of the best standard building practice used at the present time. Building D, finally, is typiral nf new housco with very liigh ellergy efficiency, particularly superinsulated designs, that are now being built in small numbers in colder climates and which are expected to become more common in futurc years. Building D uses an air-to-air heat cxchanger to mainlain the effective infiltration rate at $0.5 \mathrm{ACH}$. The heat loss is kept low because these devices can have a heat recovery efficiency of about 70 percent.

Heat losses are generally expressed in terms of a thermal transmittance value, U, or U-value. $U$ is expressed as Btu per hour per square foot of building surface for each degree of difference between the inside and outside temperatures, or $\mathrm{Btu} / \mathrm{ft}^{2} \mathrm{hr} . \mathrm{O}_{\mathrm{F}}$. It is the reciprocal of the more familiar thermal resistance, or R-value. A R-value of 20 is equivalent to a U-value of .05. U-values for building elements are tabulated in references such as the ASHRAE Handbook of Fundamentals.17 UA is the U-value for a hirilding element, such as a window, multiplied by the area of the element in square feet. Thc units of UA are Btu/hr ${ }^{O} \mathrm{~F}$. Table 1 shows the UA values for elements of the four assumed buildings. Also shown for each building is the loss associated with infiltration of cold air into the building, expressed in the same units as the UA values.

The total UA values for the four houses are $972,603,361$ and $170 \mathrm{Btu} / \mathrm{ft}^{2}$ ${ }^{\circ} \mathrm{F}$, respectively. The losses of Building $\mathrm{D}$ are only 17 percent as great as Lhuse of Building A.

Table 2 shows the "design heating load" for each of the four houses in each of six geographical locations. As used in this table, it is the heat that would be lost from the house when the inside temperature is $68^{\circ} \mathrm{F}$ and the outside temperature is equal to the figure in parentheses after each city. These temperatures are the "dnsign" temperaturcs for each localion from the ASHRAE Handbook. They are the extreme winter temperatures which building designers consider to determine the required capacity of the heating system to be installed in a new home.*

*The design temperatures shown in the table are the temperature extremes experienced during 97.5 percent of the time in the period December through February. It could be colder 2.5 percent of the time, or about 54 hours, based on climatic data for the period 1941-1970. 


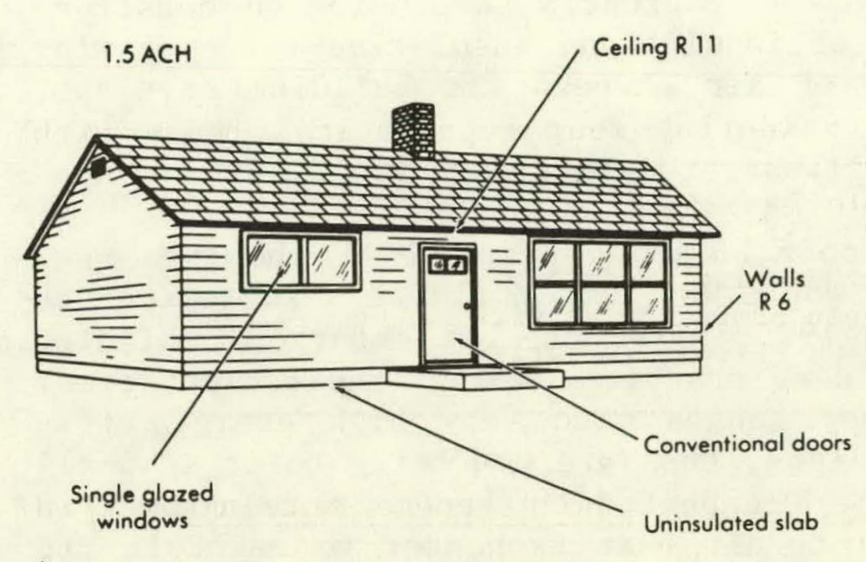

BUILDING A

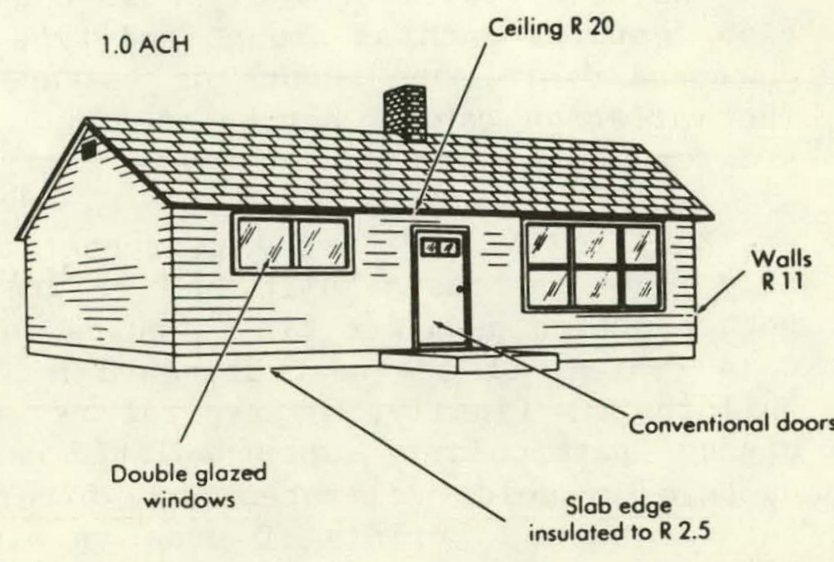

BUILDING B

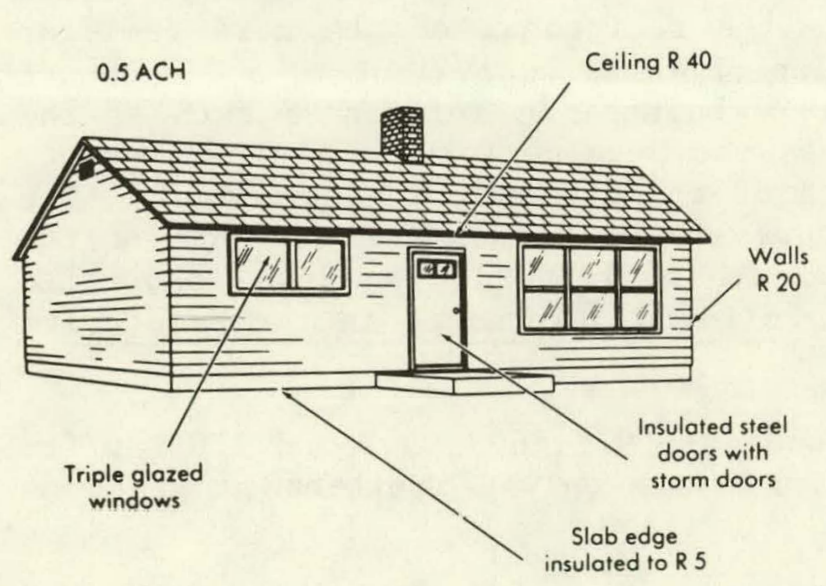

BUILDING C

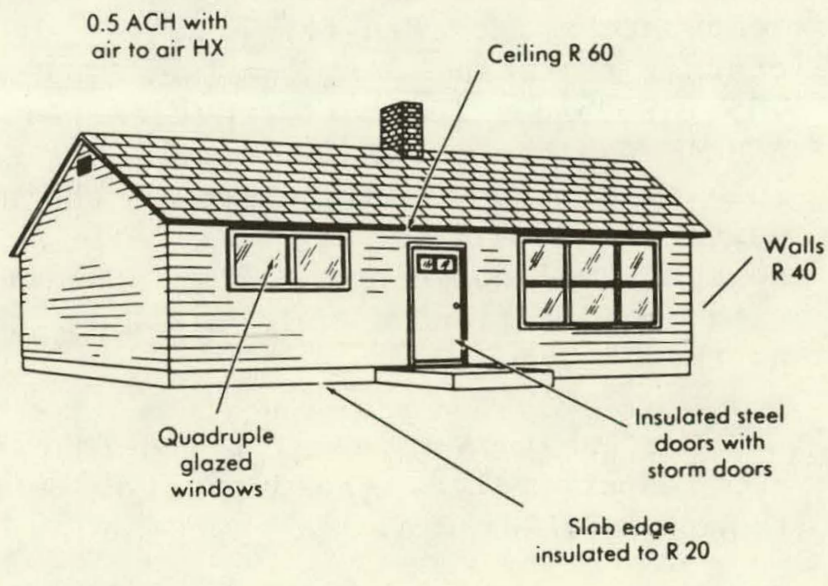

BUILDING D

Figure 2. Single Story Houses with Four Levels of Envelope Thermal Integrity. 


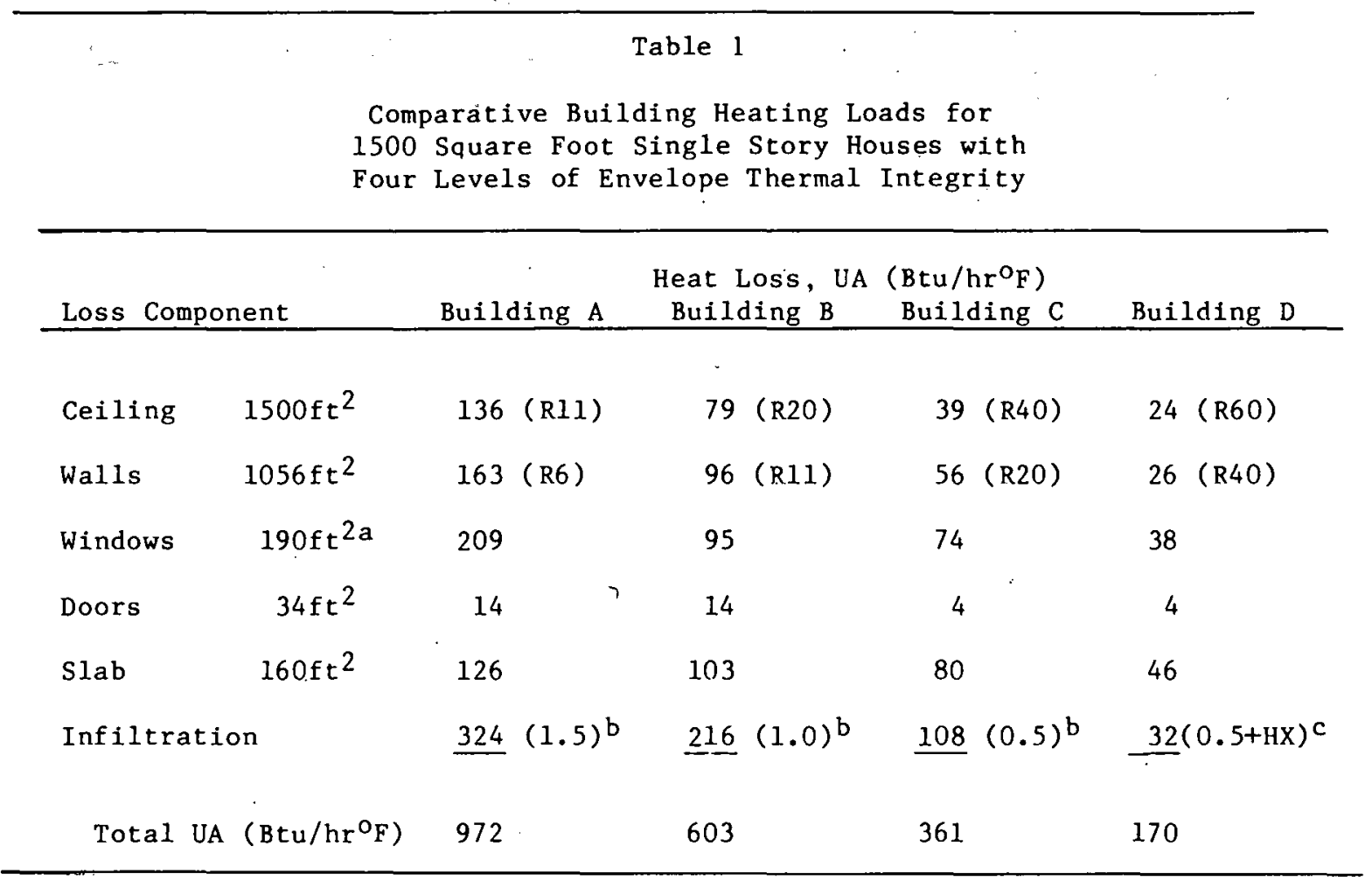

$a_{60 f t^{2}}$ of glazing on south side.

$b_{\text {Air }}$ changes per hour.

$\mathrm{c}_{0.5}$ air changes per hour with $70 \%$ heat recovery using air to air heat exchanger. 
Design Heating Loads at $68^{\circ} \mathrm{F}$ Inside

Temperature ( $\bar{B} t u / h r)$

\begin{tabular}{|c|c|c|c|c|}
\hline $\begin{array}{l}\text { Location and } \\
\text { Design Temp. }\end{array}$ & $\begin{array}{r}\text { Des } \\
\text { Butlding } \Lambda \\
\end{array}$ & $\begin{array}{l}\text { n Heating Load } \\
\text { Building } \mathrm{B} \\
\end{array}$ & $\begin{array}{l}\text { in Btu/hr } \\
\text { Building C }\end{array}$ & Building D \\
\hline $\begin{array}{l}\text { Minneapolis, MN } \\
\left(-12^{\circ} \mathrm{F}\right)\end{array}$ & 77,800 & 48,200 & 28,900 & 13,600 \\
\hline $\begin{array}{l}\text { Omaha, NB } \\
\left(-3^{\circ} \mathrm{F}\right)\end{array}$ & 69,000 & 42,800 & 25,600 & 12,100 \\
\hline $\begin{array}{c}\text { Boston, MA } \\
\left(9^{\circ} \mathrm{F}\right)\end{array}$ & 57,300 & 35,000 & 20,900 & 9,900 \\
\hline $\begin{array}{l}\text { Wachington; DC } \\
\quad\left(17^{\circ} \mathrm{F}\right)\end{array}$ & 49,600 & 30,800 & 18.400 & 8,700 \\
\hline $\begin{array}{c}\text { At lanta, } \\
\left(22^{\circ} \mathrm{F}\right)\end{array}$ & 44,700 & 27,700 & 16,600 & 7,800 \\
\hline $\begin{array}{c}\text { Dallas, TX } \\
\left(22^{\circ} \mathrm{F}\right)\end{array}$ & 44,700 & 27,700 & 16,600 & 7,800 \\
\hline
\end{tabular}


As indicated in Table 2, Building $A$ has a design heating load of 77,800 $\mathrm{Btu} / \mathrm{hr}$ in Minneapolis, but only $44,700 \mathrm{Btu} / \mathrm{hr}$ in Atlanta or Dallas. For Building $\mathrm{D}$, the load drops to only $13,600 \mathrm{Btu} / \mathrm{hr}$ in Minneapolis and 7,800 $\mathrm{Btu} / \mathrm{hr}$ in Atlanta or Dallas.

\section{B. Seasonal Heating Requirements}

The design heating load is important for determining the maximum heat output that the heating system must be capable of supplying to the house. The annual heating requirement of a house, however, which is of equal interest, requires a different type of analysis and consideration of other sources of heat that are available to maintain comfortable temperatures. Consideration must be given to internal sources of heat, such as metabolic heat released by occupants and heat released by lighting and appliances, and also to the solar heat received through windows, which can be signiflcant even in houses with conventionally sized and arranged windows.

By taking consideration of internal sources of heat and solar gain, a "balance point" temperature can be estimated for a house. It is basically the outside temperature above which no heat is required from the furnace or other auxiliary heat source. It is of ten well below $65^{\circ} \mathrm{F}$ in new energy-efficient houses. The ASHRAE 1981 Handbook of Fundamentals, 17 in a new Chapter 28 dealing with heating energy estimating methods, provides the following discussion of the subject of balance point temperatures.

\footnotetext{
"Degree days are a temperature statistic for predicting the energy loss of buildings through the building's surface and ventilative conductances because of inside-tooutside temperature differences. Assuming that energy transfer over time is linearly related to the inside-tooutside temperature difference, the accumulation of insideto-outside temperature differences over time will give the energy loads on the building over that time.

The degree-day procedure is intended to recognize that, although the energy transferred out of a building is proportional to the difference betwen interior space temperature and the nutside temperature, the furnace needs to meet only the part that is not covered by "free heat" from internal sources such as lights, equipment, occupants, and solar gain. In other words, the free heat covers energy requirements down to the balance point temperature, below which the energy requirements of the furnace are proportional to the difference between the balance point temperature and the outside temperature."
}

For our four hypothetical. houses, we have assumed the internal heat to be $60,000 \mathrm{Btu} /$ day. This is a representative figure for a family of three or four with the usual complement of lighting and appliances. Solar gain is estimated at $42,000 \mathrm{Btu} / \mathrm{day}$, which is based on a modest 60 square feet of south-facing windows and solar intensity of $700 \mathrm{Btu} / \mathrm{ft}^{2}$ day. Together, these sources of free heat contribute 102,000 Btu/day, on average, during the heating season, 
to meeting the heating needs of the houses. The contribution (particularly the solar component) varies, however, from day to day.

Balance point temperatures are obtained by dividing 102,000 by the hourly heat losses of the house (from Table 1) multiplied by 24 , and subtracting the resultant figure from $68^{\circ} \mathrm{F}$. They are $63.6^{\circ} \mathrm{F}, 61.0^{\circ} \mathrm{F}, 56.2^{\circ} \mathrm{F}$ and $43.0^{\circ} \mathrm{F}$, respectively, for the four houses.

Degree day statistics for various bases other than $65^{\circ} \mathrm{F}$ are available from several sources. One of these is Volume. 2 of the Passive Solar Design Handbook prepared by Los Alamos Scientific Laboratory. 4 Annual auxiliary heating requirements of the four houses are developed for six geographical locations, in Table 3. The degree-days for a $65^{\circ} \mathrm{F}$ base temperature are shown below the name of each city, in parentheses. 4 To the right, also in parentheses, are the reduced degree-days corresponding to the balance point temperatures for the four houses. Also shown are the annual auxiliary heat requirements for each house in each location, expressed in termo of millions of Btu per yedr.

As sluwn In Table 3, Bullding A needs 1811.1 millinn Btu of auxiliary heat per year in Minneapolis but only $46.9 \mathrm{million} B$ tu in Dallas. The Building C requirement in Minneapolis drops sharply to 51.6 million Btu, and Building $D$ requires only 12.6 million $B t u$. Building $C$ needs very litt le auxiliary heat in At lanta and Dallas, and Building $D$ has no requirement for auxiliary heat in those locations. The performance of Buildings $C$ and $D$ in those locatinns should be taken only as illustrative examples of what is possible. In practice, it would not be economic to invest in the energy-conserving features of these low-energy houses in such mild climates.

Table 4 presents the auxiliary heat required for houses of the four levels of energy efficiency, in each of the six cities, in units of millions of Btu per 1,000 square feet of floor space per year. 'l'he figures are based on an assumption that heat needs are proportional to floor area for a particular house design. 'l'his assumption has been shown to be reasonably valid.1 Table 4 permits estimation of the auxiliary heat needs of houses of other sizes than 1,500 square feet.

The analysis in later sections of this report will be confined to the needs of low-energy houses typical in thermal performance of Buildings $C$ and D.

\section{Space Heating Costs}

The prices of the forms of energy most used for central space heating of homes are shown in Table 5.* They are the average prices in 1980 for the states in which the six example cities are located, as reported recently by the U.S. Department of Energy.18 1980 is the latest year for which complete price data is compiled. Also shown are the costs per million Btu of heat delivered to the building space, based on representative values of conversion efficiency.

*The term propane is used in this report for liquefied petroleum gas (LPG or LP-gas). Virtually all of the L.PG on the retail market today is propane or a mixture of propane and butane, with propane predominating. 18 
Table 3

Annual Auxiliary Heat Requirements of 1500 Square Foot Houses

\begin{tabular}{|c|c|c|c|c|}
\hline \multicolumn{5}{|c|}{ Millions of Btu Per Year and Degree Days } \\
\hline $\begin{array}{l}\text { Location } \\
\text { and } \mathrm{DD}_{65}\end{array}$ & $\begin{array}{l}\text { Bullding A } \\
\text { Balance Point } \\
\text { Temp. } 63.6^{\circ} \mathrm{F}\end{array}$ & $\begin{array}{l}\text { Building } \mathrm{B} \\
\text { Balance Point } \\
\text { Temp. } 61.0^{\circ} \mathrm{F}\end{array}$ & $\begin{array}{l}\text { Building C } \\
\text { Balance Point } \\
\text { Temp. } 56.2^{\circ} \mathrm{F}\end{array}$ & $\begin{array}{l}\text { Bullding D } \\
\text { Balance Point } \\
\text { Temp. } 43.0^{\circ} \mathrm{F}\end{array}$ \\
\hline $\begin{array}{l}\text { Minneapolis, MN } \\
\quad(8,159)\end{array}$ & $\begin{array}{l}180.1 \\
(7,720)\end{array}$ & $\begin{array}{c}102.5 \\
(7,080)\end{array}$ & $\begin{array}{c}51.6 \\
(5,950)\end{array}$ & $\begin{array}{l}12.6 \\
(3,080)\end{array}$ \\
\hline $\begin{array}{l}\text { Omaha, NB } \\
(6,601)\end{array}$ & $\begin{array}{l}144.6 \\
(6.200)\end{array}$ & $\begin{array}{c}80.6 \\
(5,570)\end{array}$ & $\begin{array}{c}39.4 \\
(4,550)\end{array}$ & $\begin{array}{c}8.5 \\
(2,070)\end{array}$ \\
\hline $\begin{array}{r}\text { Boston, MA } \\
(5,621)\end{array}$ & $\begin{array}{l}121.5 \\
(5,210)\end{array}$ & $\begin{array}{c}65.8 \\
(4,550)\end{array}$ & $\begin{array}{c}30.8 \\
(3,550)\end{array}$ & $\begin{array}{c}4.4 \\
(1,080)\end{array}$ \\
\hline $\begin{array}{c}\text { Washington, DC } \\
(5,010)\end{array}$ & $\begin{array}{c}108.5 \\
(4,650)\end{array}$ & $\begin{array}{c}59.0 \\
(4,080)\end{array}$ & $\begin{array}{c}26.8 \\
(3,090)\end{array}$ & $\left(\begin{array}{l}3.6 \\
880\end{array}\right)$ \\
\hline $\begin{array}{c}\text { Atlanta, GA } \\
(3,095)\end{array}$ & $\begin{array}{c}65.1 \\
(2,790)\end{array}$ & $\begin{array}{c}33.3 \\
(2,300)\end{array}$ & $\begin{array}{c}13.0 \\
(1,500)\end{array}$ & $\begin{array}{l}0 \\
0\end{array}$ \\
\hline $\begin{array}{r}\text { Dallas, TX } \\
(2,290)\end{array}$ & $\begin{array}{c}46.9 \\
(2,010)\end{array}$ & $\begin{array}{c}23.9 \\
(1,650)\end{array}$ & $\begin{array}{c}9.1 \\
(1,050)\end{array}$ & $\begin{array}{l}0 \\
0\end{array}$ \\
\hline
\end{tabular}


Table 4 .

Annual Auxillary Heat Requiremento of Single Family Houoco

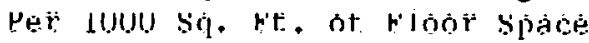

\begin{tabular}{lcccc}
\hline & $\begin{array}{c}\text { Millions of } \\
\text { Location }\end{array}$ & Btu per 1000 & $\mathrm{ft}^{2}$ Floor Space Per Year \\
& & & & \\
Building A & Building B & Building C & Building D \\
Minneapolis, MN & 120.1 & 68.3 & 34.4 & 8.4 \\
Omaha, NB & 96.4 & 53.7 & 26.3 & 5.6 \\
Bostion, MA & 81.0 & 43.9 & 20.5 & 2.9 \\
Washington, DC & 72.3 & 39.4 & 17.8 & 2.4 \\
Atlanta. GA & 43.4 & 22.2 & 8.7 & 0 \\
Dallas, TX & 31.3 & 15.9 & 6.1 & 0 \\
\hline
\end{tabular}


Also shown in Table 5 are costs per million Btu as purchased and as delivered to the space to be heated. The conversion efficiencies used for gas and oil are relatively high values typical of what can be achieved by proper selection and use of new efficient heating products which are now available on the market.

As developed in Table 5, the cost of providing a million Btu to heat a home at 1980 prices for the selected states ranged from about $\$ 12$ to $\$ 20$ for electric resistance heating, $\$ 3.40$ to $\$ 6.80$ for gas heat, $\$ 8.00$ to $\$ 9.20$ for oil heat, and $\$ 8.50$ to $\$ 12.50$ for propane. The price of natural gas has risen significantly since 1980, however, while the current price of heating oil is about the same as in 1980. As a result, the gap between gas and oil heating costs has been greatly reduced.

The approximate costs to heat each of buildings $A, B, C$, and $D$ for a year in the six example locations with electric resistance, natural gas, fuel oil and propane are listed in Table 6. The costs are expressed in terms of do1lars per 1,000 square feet of floor space. For Buildings $C$ and $D$, which are the subject of this report, the following observations can be made:

1. Annual heating costs for best current standard practice energy-efficient houses (Building C) are typically less than 25 percent of those for houses with thermal characteristics typical of those built before World War II. For the best new energy-efficient designs (Building D) the costs are less than 10 percent of those for prewar models.

2. Best current practice houses (Building $C$ ) can be heated by gas and oil at reasonable cost, even in climates as cold as Minneapolis. Allowing for recent increases in the price of natural gas, the annual cost is in the order or $\$ 200$ to $\$ 450$ for an average-sized ( 1,500 square foot) home. The difference in cost among the fuels in absolute dollars (not in percent) is small enough to suggest that the fuel choice should consider other factors as well as cost.

3. Heating costs of the most energy-efficient new houses (Building D) are so low that the differences between energy sources, including electric resistance heating, are trivial.

4. The cost of auxiliary heat for Building $B$ is quite low in warmer climates such as Atlanta and Dallas. This suggests that the incremental costs for the conservation features of Building $C$ are probably seldom justifiable in those areas at current fuel prices. Similarly, the incremental cost of houses like Building $D$ would obviously not be justifiable in areas with mild winters. The figures shown for Buildings $C$ and $D$ in warmer locations are included only for purposes of illustration of extreme conditions. 
Table 5

Hearing Finergy Prices and Costs, 1981

Prices and Costs In Dollars

\begin{tabular}{|c|c|c|c|c|c|c|}
\hline \multirow[b]{2}{*}{ Heat Sourse } & \multirow[b]{2}{*}{ Minnesota } & \multicolumn{3}{|c|}{ Prices and Costs In Dollars } & \multirow[b]{2}{*}{ Georgla } & \multirow[b]{2}{*}{ Texas } \\
\hline & & Nebraska & Massachuset ts & D.C. & & \\
\hline \multicolumn{7}{|l|}{ Electric Resistance } \\
\hline s/kWh & .1942 & .040 & .069 & .055 & .044 & .047 \\
\hline$\$ / 10^{6}$ BEu purchased & 12.31 & 11.72 & 20.22 & 16.12 & 12.90 & 13.77 \\
\hline Conversion ef fictency (\%) & 1100 & 100 & 100 & 100 & 100 & 100 \\
\hline$\$ / 10^{6}$ B:u of heat & 12.31 & 11.72 & 20.22 & 16.12 & 12.90 & 13.77 \\
\hline \multicolumn{7}{|l|}{ Natural Gas } \\
\hline s/1000 cu.ft. & 3.23 & 2.73 & 5.42 & 4.57 & 3.68 & 3.41 \\
\hline$\$ / 10^{6}$ Btu purctiased & $3.2 \mathrm{~J}$ & 2.73 & 5.42 & 4.57 & 3.68 & 3.41 \\
\hline Conversion efflctency $(\%)$ & 80 & 80 & 80 & 30 & 80 & 80 \\
\hline $\mathrm{s} / 10^{6}$ Btu of heat & 4.04 & 3.41 & 6.78 & 5.71 & 4.60 & 4.26 \\
\hline \multicolumn{7}{|l|}{ Fuel 011} \\
\hline \$/gallon & .96 & .95 & .99 & 1.02 & .96 & .90 \\
\hline$\$ / 10^{6}$ Btu purchased & 6.92 & 6.85 & 7.14 & 7.35 & 6.92 & 6.49 \\
\hline Conversion: ef f lc1 ency $(\%)$ & 80 & 80 & 80 & 30 & 80 & 80 \\
\hline$\$ / 10^{6} \mathrm{BCu}$ of heat & 8.65 & 8.56 & 8.93 & 9.19 & 8.65 & 8.11 \\
\hline \multicolumn{7}{|l|}{ Propane (LPG) } \\
\hline \$/gallor. & .67 & .62 & .82 & .91 & .70 & .68 \\
\hline$\$ / 10^{6}$ Btu purchased & 7.31 & 6.77 & 8.95 & 9.93 & 7.64 & 7.42 \\
\hline Conversion ef fi=iency ( $\%$ ! & 80 & 80 & 80 & 80 & 80 & 80 \\
\hline$\$ / 10^{6}$ Btu of heat & 9.14 & 8.46 & 11.19 & 2.41 & 9.55 & 9.28 \\
\hline
\end{tabular}

Source of energy prices: Reference 19. 


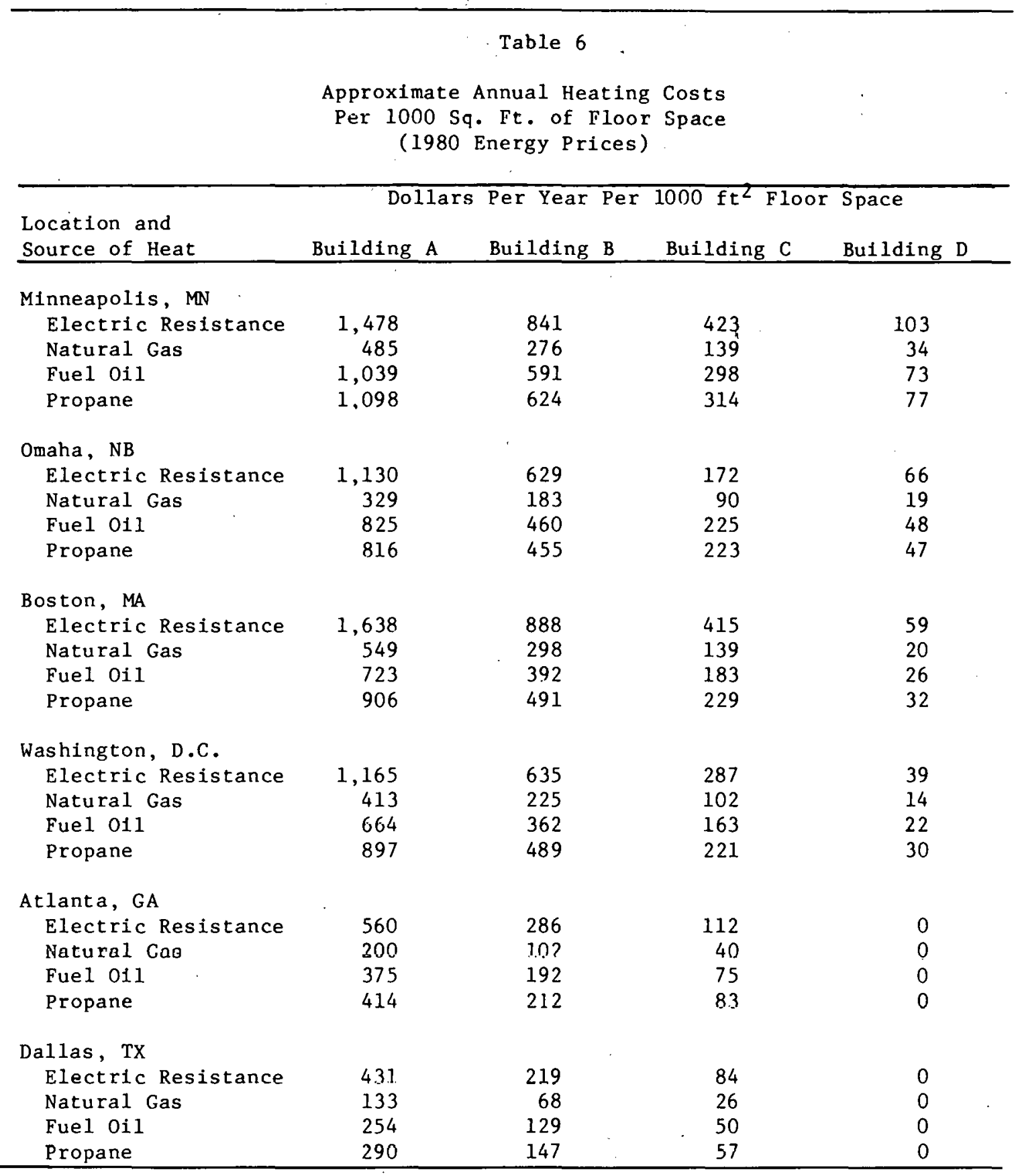




\section{DOMESTIC HOT WATER ENERGY REQUIREMENTS}

A. Hot Water Use

The typical usage of hot water in a residence is shown in Table 7, which is based on data from Reference 20.

Table 7

Hot Water Use in Single Family Residences

\begin{tabular}{ll} 
Use & $\begin{array}{l}\text { Average Gallons of } \\
\text { Hot Water per Use }\end{array}$ \\
\hline
\end{tabular}

Shower

20

Bath

20

Shaving

Hands and Face Washing

Hair Shampoo

Hand Dishwashing

Automatic Dishwasher

Food Preparation

2

4

Wringer Clothes Washer

4

4

14

Automatic Clothes Washer

Average hot water use in U.S. homes is estimated to be about 450 gallons per week, or 64.3 gallons per day. 21 It is based on a survey of gas and electric utilities which provided information on the average use by families of four living in single family houses. Some households will use more and some will use less, but this usage is considered to be a good average.

\section{B. Energy Costs}

The heat required to warm 64.3 gallons of water $90^{\circ} \mathrm{F}$ (from $50^{\circ} \mathrm{F}$ to $140^{\circ} \mathrm{F}$ ) is $48,264 \mathrm{Btu}$. This amounts to about $17.6 \mathrm{million}$ Btu over a full year. The efficiency at which the heater delivers this heat varies greatly among $\mathrm{DHW}$ systems.

Comparative annual operating costs for various domestic hot water systems were estimated recently by Oak Ridge National Laboratory (ORNL) 22 in connection with ORNL's research on heat pump water heaters (HPWH). Estimates were prepared for a large number of geographical locations and, in the case of the HPWH, for the location of the system within the building. Since a HPWH takes heat from its surroundings to heat water, it causes an increase in the space heating load of the house if 1 t is located within the heated space. The ORNL calculations took this into account by adding to the operating cost of the HPWH systems the additional operating cost for the space heating system. 
Conversely, the calculations credited the operating cost of the HPWH in warmer climates to account for reduced operation of the house's air conditioning system in the cooling season.

The ORNL annual operating cost estimates for selected cities are presented in Table 8. Four of the cities (Minneapolis, Boston, Washington, and Atlanta) are in the group of six cities selected earlier in the space heating analysis. Dallas was not included in the ORNL study cities, nor was Omaha, but Ft. Worth was. Key assumptions are stated at the end of the table. Since energy prices for January 1981 were used, they are reasonably close to the 1980 prices used for Tables 5 and 6 in the previous section on space heating costs. The price of natural gas has risen significantly since 1980, as noted earlier. Therefore, the cost of gas DHW heating would be considerably higher at current prices, relative to some of the other systems, than shown in Table 8 .

The annual costs of space heat and $\mathrm{DHW}$ for various houses and locarlons, at 1980-1981 energy prices, are compared in Figure 3. The space heat costs are based on a 1,600 square foot house, for consistency with the ORNL DHW cost data. The cost ranges retlect the full range of system options in Tables 5 and 8. Omaha is not included as a location because it was not included in the ORNL study. The cost of space heat energy for Building $D$ is seen to be less than that for hot water even in Minneapol1s. The space heat energy costs for Building $C$ are roughly equal to the DHW energy costs in all cities except Minneapolis, where the space heat cost is somewhat more than that for DHW. The high ranges of costs for both space heat and DHW in Boston reflect the high costs of natural gas and electricity in that clty. 
Table 8

Annual Operating Cost of Domestic Hot Water Heaters Derived from ORNL Study, Reference 22

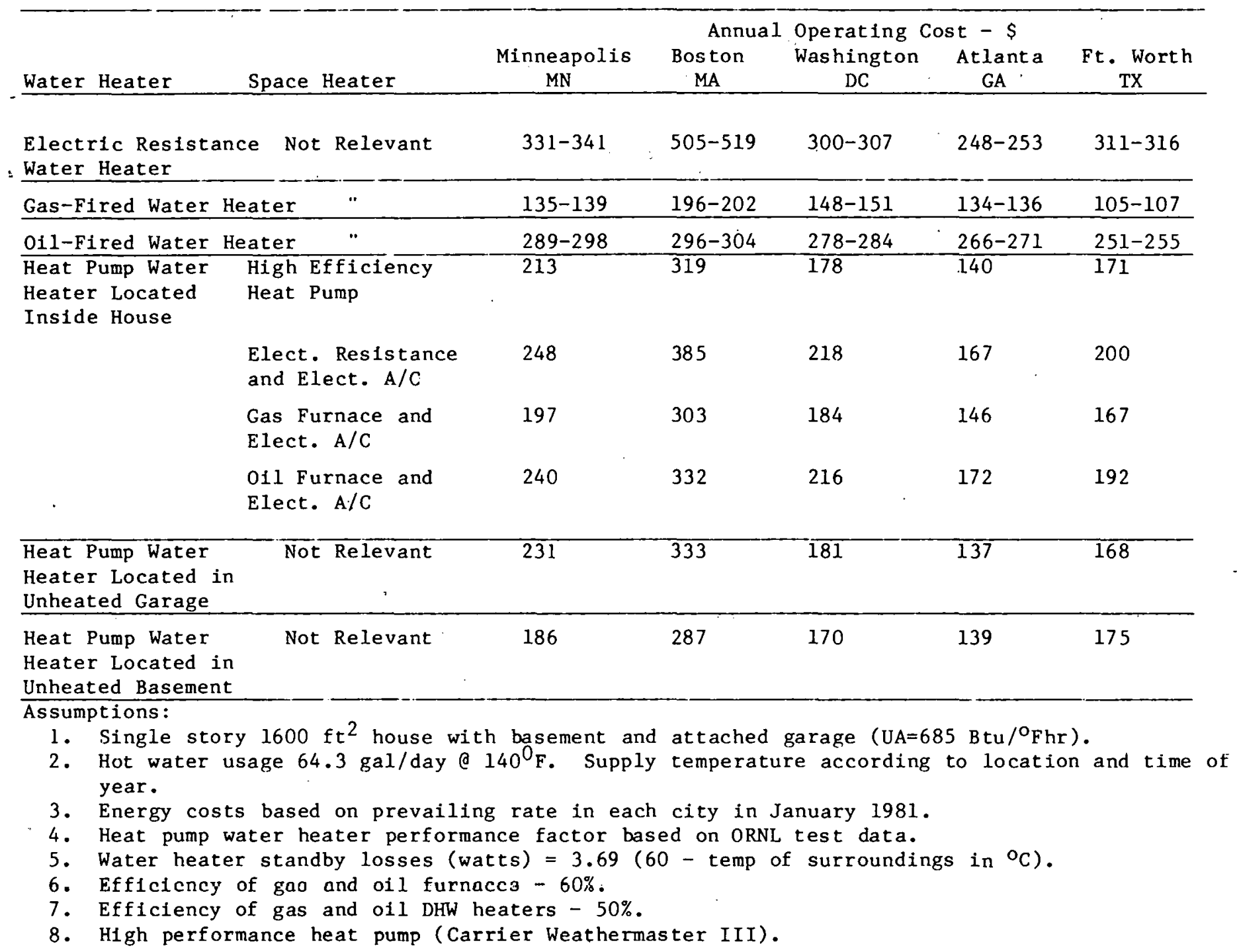




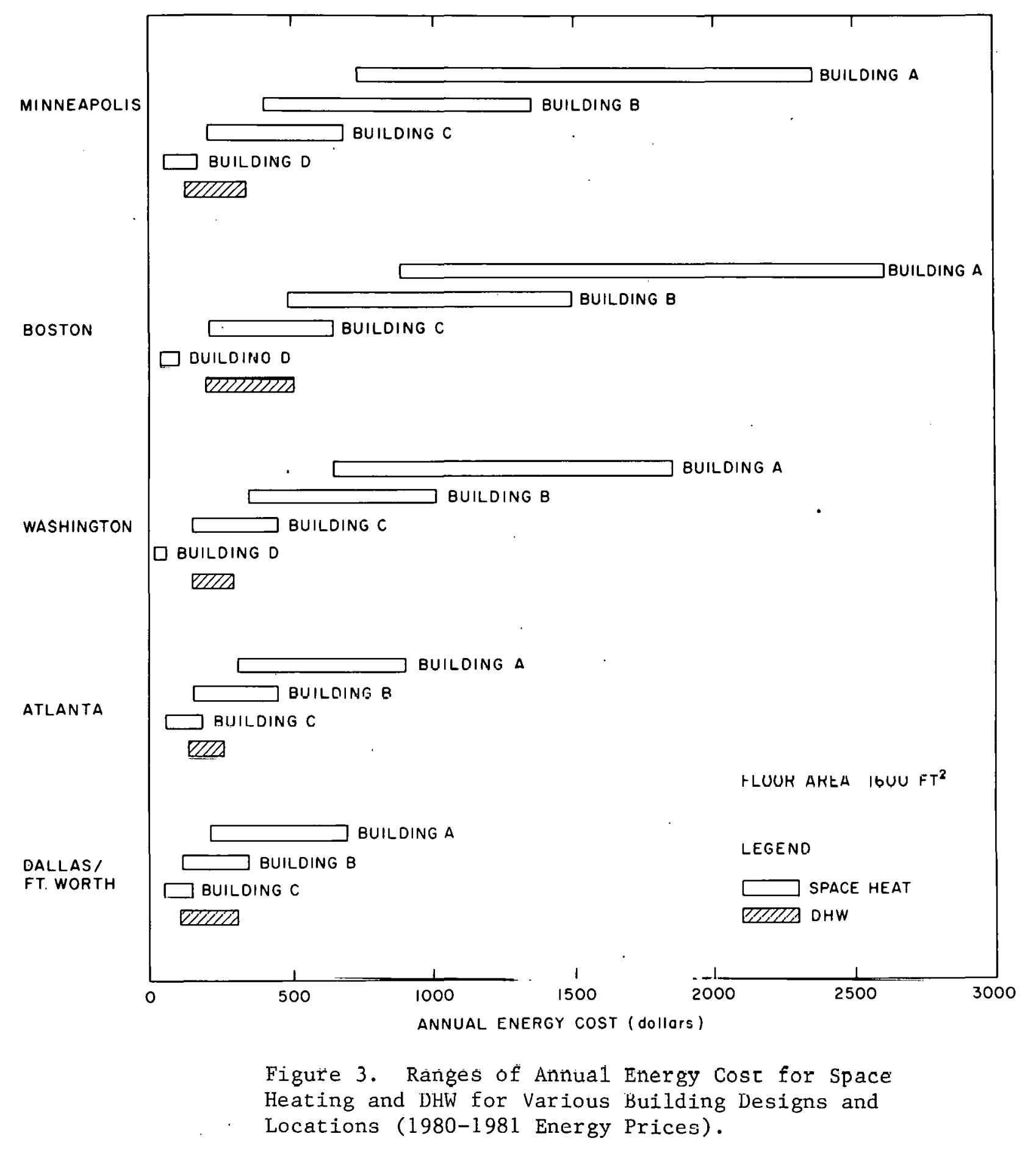




\section{EQUIPMENT OPTIONS AVAILABLE TO HOME DESIGNERS}

\section{A. Space Heating}

1. Central Furnaces and Boilers

A large number of makes and models of furnaces and boilers are available. Most, however, have much higher heating capacity than is required for energyefficient houses. Also, the annual fuel utilization efficiency (AFUE)* varies greatly.

All furnaces and boilers manufactured on or after May 19, 1980 display "Energy Guide" labels which refer buyers to a fact sheet which shows the AFUE for the model and provides estimates of annual operating cost at various fuel prices for houses of various heat loads in various geographical areas. The AFUE is a useful figure for comparing one model with another, in the same way that EPA mileage estimates for automobiles permit comparisons.

Manufacturers initially filed AFUE and capacity data for over 9,000 models of gas and oil furnaces and boilers. Many models appear several times in the available listings, however, because of widespread private label selling, such as by Sears and Montgomery Ward. Less than 10 percent of the models have outputs of $50,000 \mathrm{Btu} / \mathrm{hour}$ or less. As indicated in Table 2, the design heating loads of Building $C$ could be met with a capacity margin of almost 100 percent by furnaces or boilers with a $50,000 \mathrm{Btu} /$ hour output.

The wide variation in efficiency of furnaces and boilers is evident from Figure 4. Some gas-fired models have AFUEs only in the 50-60\% range. Other models, however, have AFUEs in the $80-90 \%$ range. Oil furnaces and boilers have a smaller (but still large) range of AFUEs. Many oil models are avai1able in the AFUE range of $80-90 \%$.

The directorles on wh1ch these data are based are now up to two years old.23,24,25,26 Most of the major manufacturers have since introduced new high efficiency models, and also some models with lower outputs, down to $20,000 \mathrm{Btu} /$ hour. As a result, a wider range of low output high efficiency equipment, particularly gas-fired furnaces, is now available for use in energy-efficient houses. For example, Lennox has introduced a Conservator (G12) gas furnace line which includes models, at the lower end, with outputs of $22,000,32,000$, and $42,000 \mathrm{Btu} /$ hour, with AFUEs from $68.1 \%$ to $81.7 \%$.

The Gas Appliance Manufacturers Association (GAMA) has established a residential furnace and boller efficiency certification program, based on the DOE test procedure, which includes semi-annual publication of a Directory of

*Annual Fuel Utilization Efficiency (AFUE) is a representation of the overall efficiency of a system over a complete heating season based on average conditions, including on and off cycling. The AFUE for each model is obtained by testing in accordance with standardized Department of Energy test procedures. 


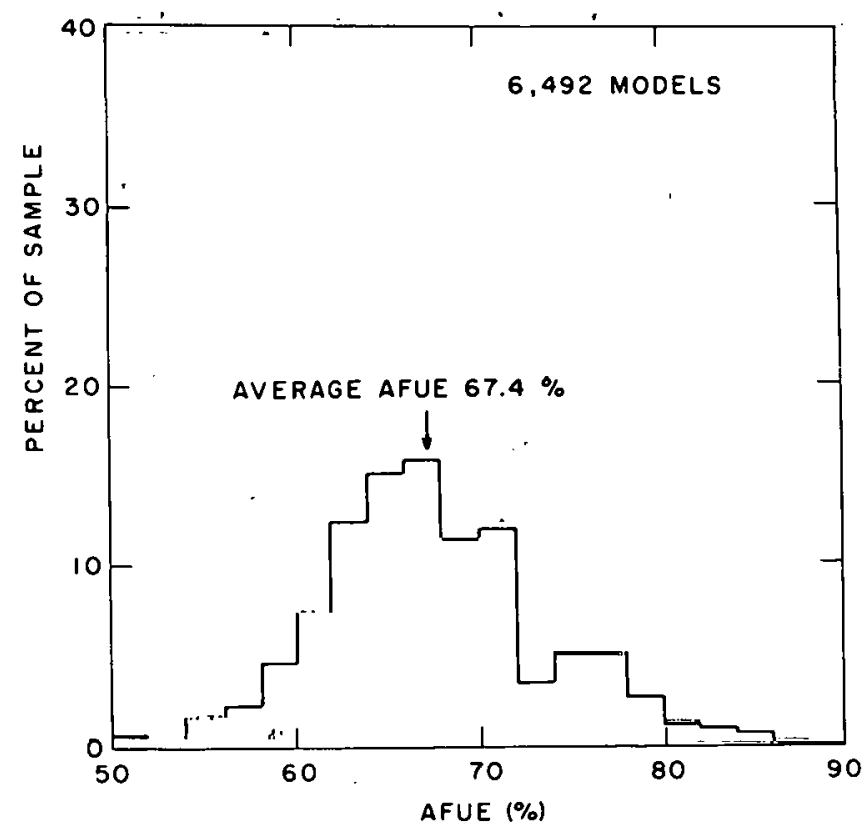

a. Gas furnaces

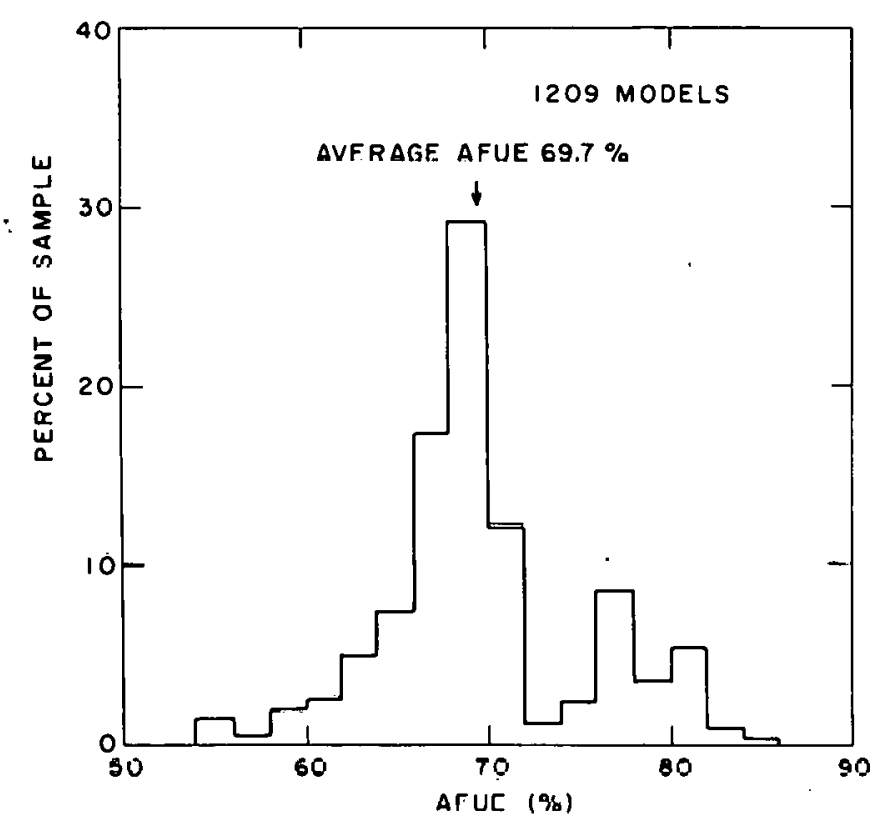

c. Gas bollers

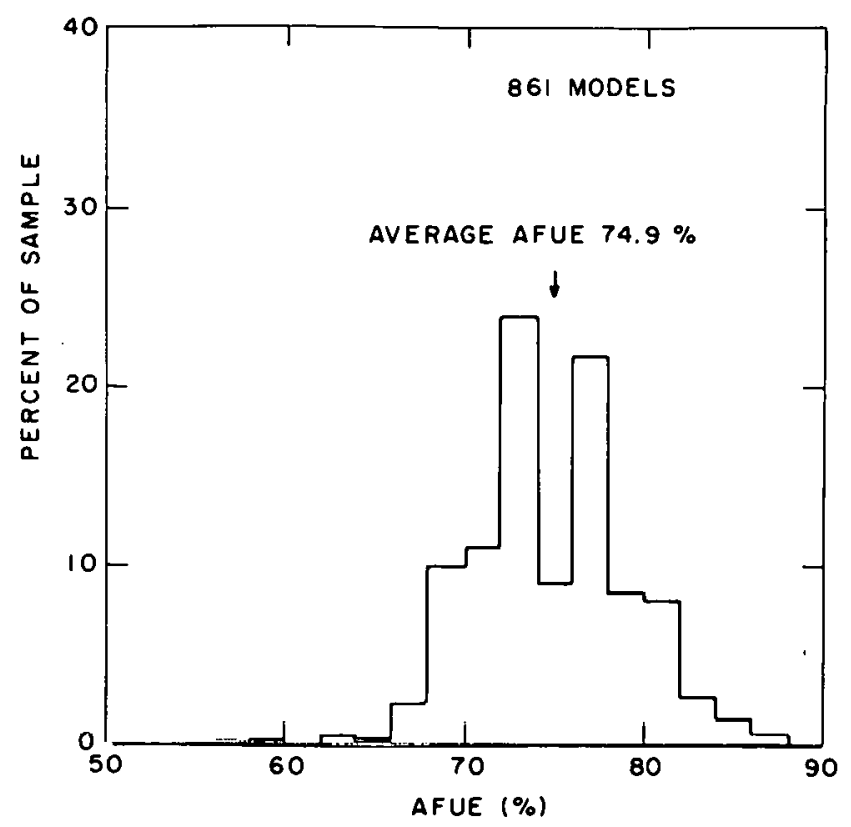

b. Oil furnaces

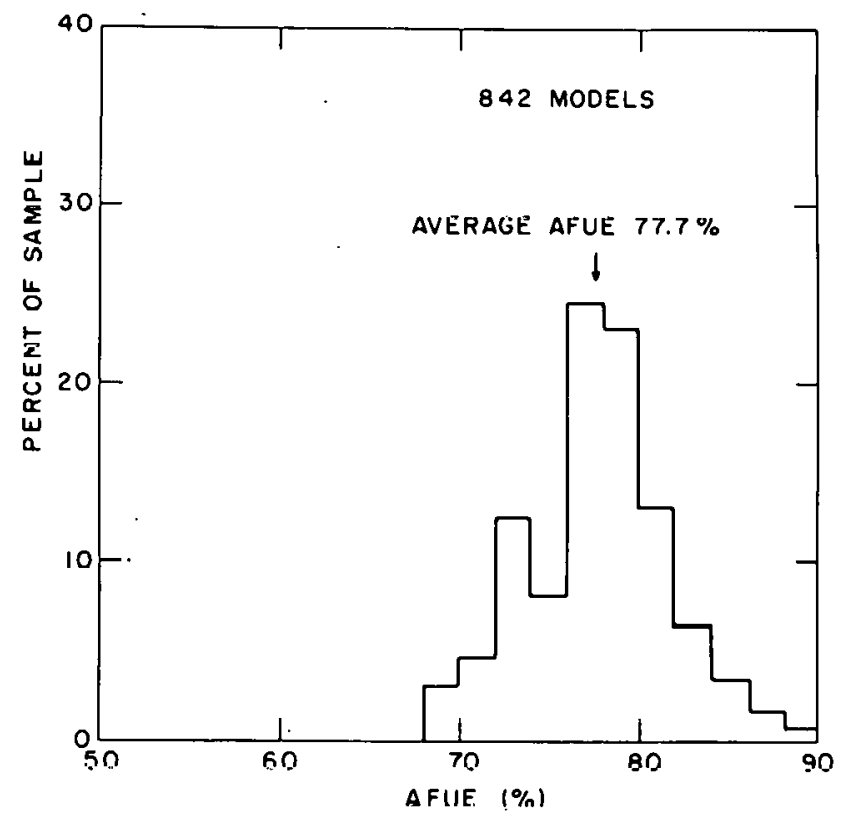

d. Oil boilers

F1gure 4. AFUE D1stribution for All Gas and Oil Furnaces and Boilers with Energy Guide Labels (1980). 
Certified Furnace and Boiler Efficiency Ratings. The first directory was issued in October 1982.27 This directory and future issues are available from GAMA, 1901 North Fort Myer Drive, Arlington, VA 22209. New models are added to the directory as they come on the market.

If a central gas or oil furnace or boiler is to be considered for heating a new energy-efficient home, it would be advisable to investigate the availability of systems having both low heat output and high efficiency. Because of the high rate of new product introductions, it would probably be useful to write to manufacturers or distributors in addition to asking for advice from local heating contractors.

The loss in efficiency when central heating systems are operated below their full capacity is shown in Figures 5 and 6 . The effect is different for furnaces than it is for boilers. These curves, based on tests conducted in a BNL laboratory, are plots of overall efficiency versus running time. Since all systems cycle on and of $f$ under control of a thermostat, they are on only part of the time. Overall efficiency is the heat delivered to the distribution system as a percent of the heating value of the fuel burned during on and off operation. Running time is the fraction or percent of the hours in a day when the system is actually firing. The efficiency at the far right, at $100 \%$ running time, called the steady state efficiency, is the efficiency of the furnace or boiler during continuous operation. At lower running times the overall efficiency starts to fall off, and in the case of boilers it falls sharply at very low running times.*

The reason for the fall off in efficiency at lower running times is that heat in the combustion chamber is lost up the chimney each time the system shuts off. That heat must be replaced when the system next turns on. Furnaces have relatively little mass so the loss is not very large. Moreover, the furnace blower is allowed to run for a few minutes after the burner goes off to extract part of the heat. Boilers have more mass and therefore store more heat.. Also boilers, unlike furnaces, are usually controlled to keep the heating medium (water) hot at all times, not only when the house is calling for heat. As a result, a boiler has greater heat losses than a furnace when not operating. That is why the overall efficiency for most boilers drops so much at low running times, such as when the boiler is much too large to meet the heating needs of the house. Even if the boiler is reasonably sized, its running time percentage is still very low at the beginning and end of the heating season, when the house needs only a modest amount of heat.

New gas furnaces with outputs as low as $20,000 \mathrm{Btu} / \mathrm{hr}$ are now available. In the case of oil-fired systems, units with capacities below about 60,000 $\mathrm{Btu} / \mathrm{hr}$ are not yet available, though some have been under development and may become available in the future. The detrimental effects of boiler oversizing can be eliminated, however, by adoption of certain new design and operating

*The curves in Figure 6 are for oil-fired boilers. A set of curves for gasfired boilers would be similar in their relationship, but the efficiencies would be somewhat lower. 


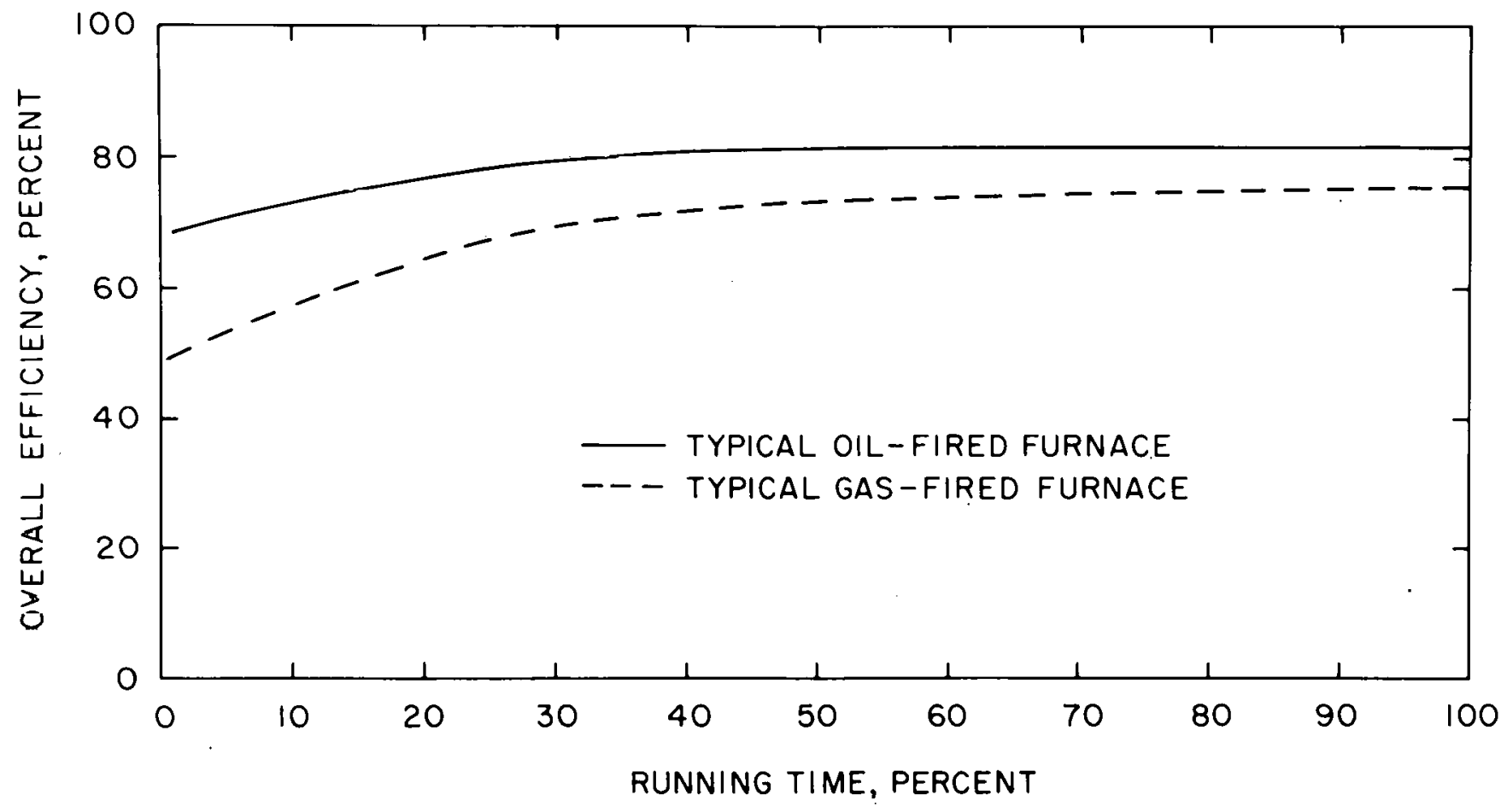

Higure 5. Part Load Efficiency of Residential Furnaces.

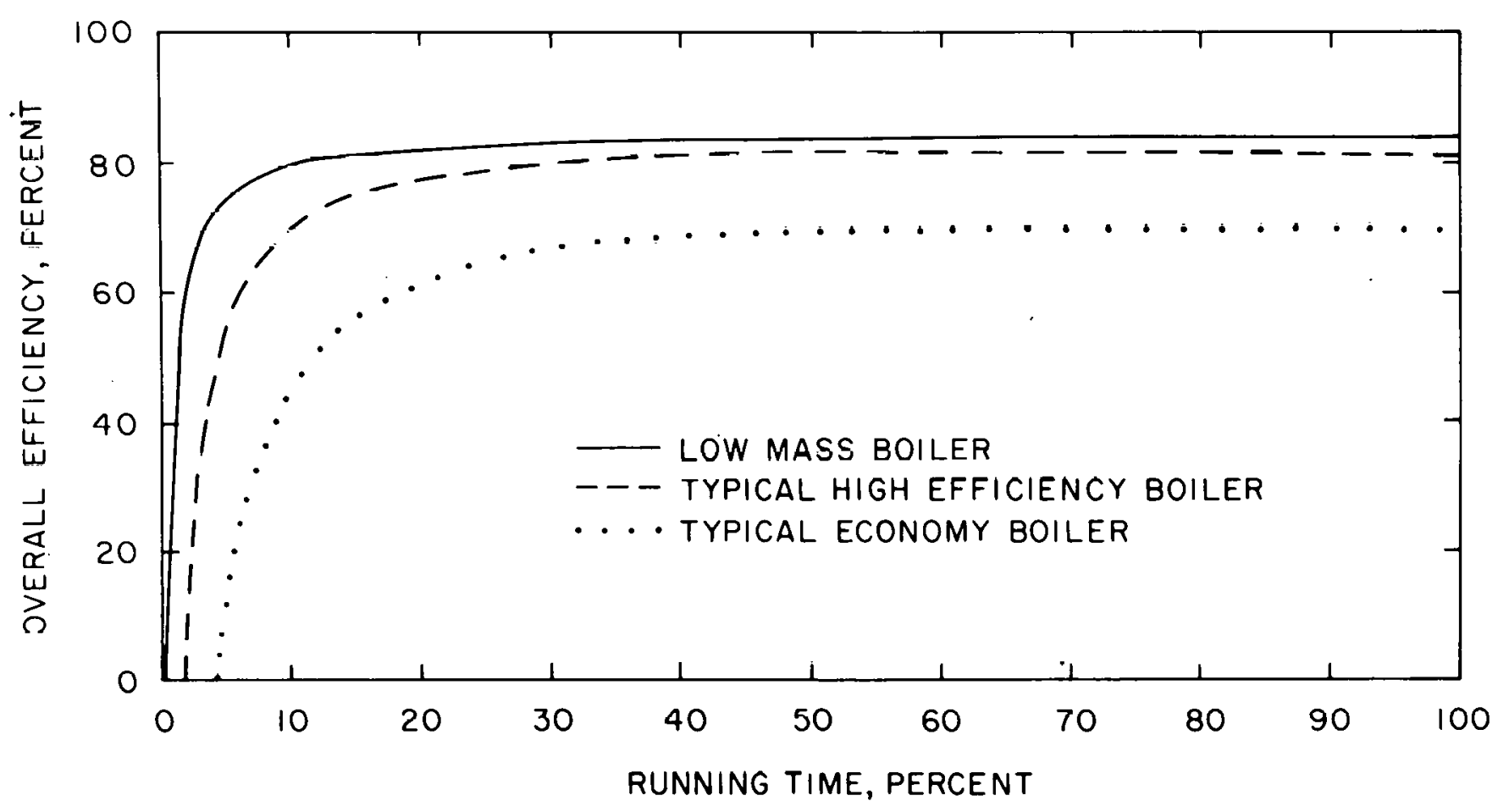

Figure 6. Part Load Efficiency of Oi1-Fired Residential Boilers. 
control strategies. These include having a relatively low mass and a small volume of water in the boiler which reduces the amount of heat stored and subject to loss when the burner is off. In addition, the circulating pump can continue to run after the burner stops firing to deliver what little heat is stored to the rooms of the house. When there is no demand for space heat or hot water, the burner remains off or the boiler water is kept at a very low temperature, which practically eliminates standby losses. Letting the boiler become cold has no adverse effect since the time required to heat up is short because of the low mass and good heat transfer.

The part-load performance of this new class of low mass boilers is indicated by the top line in Figure 6 . These boilers can have an annual fuel use efficiency almost equal to the steady state efficiency, even though they are oversized relative to the needs of the house. Well insulated storage tanks connected to the boiler can provide ample domestic hot water even though the boiler itself has a low heat capacity. A system with these features is the System 2000, manufactured by Energy Kinetics, Inc., P.0. Box 407, Bernardsville, NJ 07924. Another unit, with somewhat similar features and performance, is the Circle Combustion System, available from Circle Combustion Corp., Southside Avenue, Hastings-on-Hudson, NY 10706. A third system, widely used in England, is the Netaheat 80, available from Ener-quip, Inc., $99 \mathrm{E}$. Kansas Street, Hackensack, NJ 07601. This unit needs no chimney. It can be vented through an outside wall.

The AFUE (annual fuel utilization efficiency) figures now published for new furnaces and boilers, as discussed above, are based on a standardized test procedure. One of the simplifying assumptions underlying the AFUE figures is that the system will operate at a 22.5 percent running time when installed in a house. This should be borne in mind when referring to AFUE ratings when selecting a furnace or boiler for a house with a low space heat requirement. When the AFUEs for various models are compared, the comparison is on the basis of their performance at a 22.5 percent running time. If the system will in fact be operating at a lower running time percent, the difference in performance will be greater than the difference suggested by comparing two AFUE figures.

The differences discussed above are particularly significant in the case of boilers. The three boilers whose performance is shown in Figure 6 have overall efficiencies ranglng from 63 percent to 82 percent at 22.5 percent running time. If the boilers were operated at only 5 percent running time, the overall efficiencies would range from 13 percent to 75 percent. This suggests that a boiler for a house with a low heating load should be selected very carefully.

Most natural gas furnaces are available in models capable of operating with propane. They differ from the natural gas models in the burner orifice size and gas controls. The orifices are much smaller because propane has a higher density and heating value. The controls must provide for shutoff of the pilot gas if the pilot ignition fails. Since propane is heavier than air (unlike natural gas), it can accumulate in an enclosed area such as a basement and present an explosion hazard, especially when another source of ignition such as a propane water heater is located in the same area. 
Electric central furnaces can also be considered for new houses with small needs for auxiliary heating energy, particularly in areas where electricity rates are low. Almost six million U.S. homes are heated with electric furnaces. One advantage is that they are available in low capacities, including $17,000 \mathrm{Btu} / \mathrm{hour}(5 \mathrm{~kW})$ and $34,000 \mathrm{Btu} / \mathrm{hour}(10 \mathrm{~kW})$. While the cost of electricity is relatively high on an energy-content basis, these furnaces convert electric energy to heat at an efficiency of 100 percent.

\section{Heat Pumps}

When a house needs mechanical cooljng during the summer, as well as heating in the winter, a heat pump should be considered. At present, heat pumps are being installed in one of every three air conditioned homes. However, heat pumps tend to be least efficient on the coldest days of the winter, when they use electric resistance heating elements. Low energy houses, more than other houses, have their heating needs confined to relatively cold days. (See balance point temperature discussion in Section III.) Therefore, in view of the relatively high cost and increased maintenance of heat pumps, they may nut offer an advantage over electric resistance heating and conventional electric air conditioners in houses with very low auxillary heating needs.

When heat pumps are considered, new models such as the Carrier Breakthrough line should be evaluated. This product is a single unit through the wall heating and cooling heat pump, designed for central locations in smaller homes and condominiums, or for zoned heating and cooling in larger units. The first models, with $18,000 \mathrm{Btu} /$ hour cooling capacity, are available with backup electric heating elements ranging in capacity from 3 to $7.5 \mathrm{~kW}(10,000$ to $25,000 \mathrm{Btu} /$ hour).

An interesting multi-zone heat pump, which has been produced by Daikin Kogyo Co., Ltd. in Japan for about 12 years, is now being introduced in the United States. The system is capable of operating from two to as many as five indoor units from a single outdoor unit. It requires auxiliary (external) electric backup heat below abour $32^{\circ} \mathrm{F}$, so $1 \mathrm{t}$ is beling ofleted initially in moderate climate areas, such as Oregon and Baltimore. New uiodels wich incegral backup heating are expected to be introduced within a year.

\section{Electric Resistance Baseboard Heaters}

Electric resistance baseboard heaters are probably the most commonly selected system for meeting the auxiliary heating needs of energy-efficient houses in ways that provide automatic operation and thermostatic control. They have a low first cost and are inexpensive to install, require little or no maintenance, are relatively clean, and are quiet and reliable. Also, they permit zonlug of a liouse at luw cost. While utilities generally of fer lower kilowatt-hour charges to "all-electric" homes, the cost of electric resistance heating is nevertheless high--sometimes prohibitively high--in some parts of the country for houses with higher heating loads. 
In low energy houses such as our Buildings $C$ and $D$, however, electric resistance heating systems can be considered seriously. Because of their low first cost and the small number of hours of use, particularly when the available zone control capability is used wisely, the system can be economical.

Some companies offer hot water electric baseboard heating systems. While no more efficient than conventional electric baseboard units, they do offer, at somewhat higher installed cost, more comfort associated with longer retention of heat between thermostat cycles and more uniform convection.

4. Electric Radiant Panels

Radiant heating panels installed high on walls or in ceilings can be used as the primary auxiliary heat source, or for supplemental heat in one or more rooms. Radiant heaters warm people directly without having to first heat the air in the room. They permit heating on a room by room basis, with each room thermostatically controlled. People are comfortable when receiving radiant heat at a lower air temperature than with a convective system. Therefore, energy savings can be realized by maintaining lower room air temperatures. The system is very clean and requires little or no maintenance.

Several manufacturers offer attractive electric radiant panels specifically designed for residential use. Two of these are Aztech International, Albuquerque, NM (trademark Aztech), and TVI Energy Corporation, New Canaan, CT (trademark Energy-Kote).

\section{Electric Storage Heaters}

Another electric system, which has been widely used in Europe for many years, and which is now being offered in northern New England, is the electric storage heater. The heater, relatively large in size and usually centrally located, uses off-peak electric power to store heat in magnesite bricks. When the room thermostat calls for heat, room air is drawn into the unit by a fan, heated, and returned to the living areas. Since it has a large first cost premium over electric baseboard heat, the differential between day and night electric rates must be appreciable if its use is to be considered. With low energy houses in which a significant fraction of the space heating needs are met by solar gain, the optimal use of a storage system would be complicated by a need for predictive information about the next day's insolation and heating load. 28

\section{Vented Gas-Fired Room Heaters}

A wide range of gas-fired room heaters is available on the market, using both natural gas and propane. Some models are unvented, while others are connected to flues or use "direct" (through the wall) venting. The unvented types are not recommended for use other than for heating local areas because they must be used with caution. Unvented units are now required to have oxygen depletion safety shutoff systems. Vented natural gas or propane units can be considered, however, for use as the principal source of auxiliary heat in energy-efficient houses. Many models are available from manufacturers, including old-line firms, with outputs from as little as $5,000 \mathrm{Btu} / \mathrm{hr}$ to 50,000 
Btu/hr or more. While they are currently being marketed primarily for such uses as small offices, mobile homes and add-on rooms in single family homes, they appear to be attractive options for whole house heating when the heating load is low.

Running gas lines to individual room or area gas heaters is difficult on a retrofit basis. In new construction, however, it is relatively simple. Gas Iines are commonly run to various areas of new houses, including upper floors in some cases, for gas ranges and clothes dryers. The connection is made to the natural gas service pipe or, in the case of propane, to an outdoor storage tank.

Direct venting, or sealed combustion as it is sometimes called, has several advantages. As compared to the conventional vent (a flue connected to a chimney) it is more efficient because it uses outside air rather than heated room air for combustion. The installation through an outside wall is also simple and inexpensive. No chimney is required.

Direct vented heaters are available for through the wall installation in sleeves, like an alr conditioner, with outputs of about $10,000 \mathrm{Btu} / \mathrm{hr}$ to $40,000 \mathrm{Btu} / \mathrm{hr}$. Two or more could be used, strateglcally placed to meet the needs of the house. Others hang on the Inside of the wall, with only the vent piercing the wall. Upright counterflow direct vent wall furnaces are also available, with outputs of 30,000 to $50,000 \mathrm{Btu} / \mathrm{hr}$. Some of these have multi-room heating capacity through use of optional side outlet kits. One manufacturer offers a small unit which combines a $20,000 \mathrm{Btu} / \mathrm{hr}$ input gas furnace with a $14,000 \mathrm{Btu} / \mathrm{hr}$ electric air conditioner.

It is important that vented room heaters be installed according to instructions, preferably by professionals, and in conformance with local codes. Improper venting could result in carbon monoxide poisoning. The American National Standards Institute is now revising its voluntary standard for conventionally vented (not direct vented) space heaters to reduce this hazard. A "vent safety shutoff system" which detects any gases spilling from the draft hood will be required on new models. The system will turn of $f$ the heater if flue gas spillage takes place. New heaters are expected to have these devices in about a year.

Manufacturers of direct vent room heaters and wall furnaces include Empire Stove Co., Belleville, IL, Williams Furnace Co., Buena Park, CA, and Suburban Manufacturing Co., Dayton, $\mathrm{OH}$.

\section{Fuel Use and System Characteristics in Existing Housing}

The heating system and energy source for new houses with low heating energy needs should be made objectively. It will often depart from traditional practice. It is useful, nevertheless, to be aware of the extent of use of certain systems and fuel preferences in various regions of the country. Information on fuel use and type of heating system in the existing housing stock, based on a recent survey performed for DOE, ${ }^{29}$ is shown in Table 9 . U.S. census regtons and divisions are shown in Figure 7. 
Table 9

Fuel Use and Heating System Characteristics by Census Region, 1980

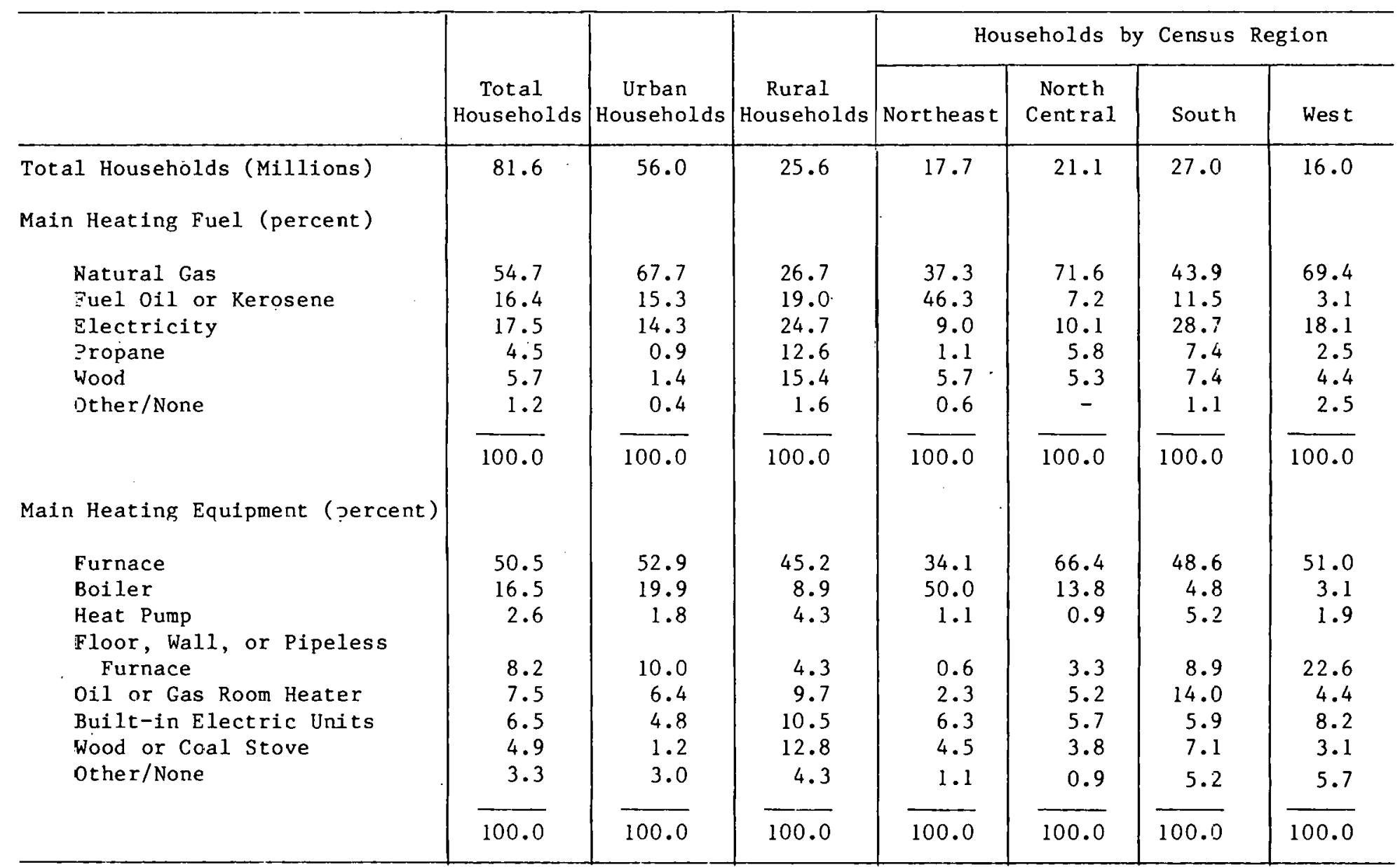

Source: Reference 29 
While 50 percent of homes in the Northeast are heated by boilers (and only 34 percent use furnaces), the furnace is dominant in the other three regions. The states included in each region are shown in Figure 7 . Two-thirds of homes in the North Central states and about half of all homes in the South and West are heated with furnaces.

Natural gas is the most commonly used main heating fuel in the North Central region, the South, and the West, where oil use is quite low. In the Northeast, however, 46 percent of homes heat with oil compared with 37 percent heating with gas.

In the South, almost 29 percent of homes heat with electricity, and 18 percent use electricity in the West. Only 9 percent of homes are heated electrically in the Northeast. A large number of rural homes (almost 25 percent) heat with electricity. This is probably due in part to gas not being available in many rural areas, but it is probably due also to the likelihood that a large fraction of rural housco, a defined by the Census Bureau, aite located in the Eouth and West, where electric heating is mule pitevaleul.

The extent to which natural gas was available to existing homes in 1981 (but not necessarily used) is shown in Table 10. The percentages were calculated based on data from a new DOE report on natural gas use. 30 While gas was available to 90 percent of Mountain division homes and 84 percent in the North Central region, the availability drops to about 63 percent in New England and about 50 percent in the South Atlantic division. Nationally, natural gas is reported to be available to 92 percent of urban households but only 42 percent of rural households. The rural (places with a population of less than 2,500 in the 1970 census) availability is only 29 percent in New England, but is 54 percent in the North Central region.*

\section{B. Domestic Hot Water Heating}

\section{Int roduction}

More than whely percent of residential bulldings rely for domestic hot water on storage-type systems where the heat source is electric resistance heating or combustion of natural gas, LP gas, or fuel oil. In the Northeast, where oil-fired boilers are common, many homes obtain DHW from a "tankless coil" immersed in the boiler water. No separate storage tank is required, though one is sometimes used. Solar DHW systems, and heat pump water heaters, which have appeared in recent years, are being selected in significant numbers for new housing construction.

The domestic hot water energy source for existing homes in 1980 , by Census regions, is indicated in Table 11.29 Natural gas, the most common choice, is

\footnotetext{
ॠThe DOE availability data is based on responses to a question "Is gas from underground pipes available in this community?" The percentages for availability at the property line would probably be significantly lower.
} 


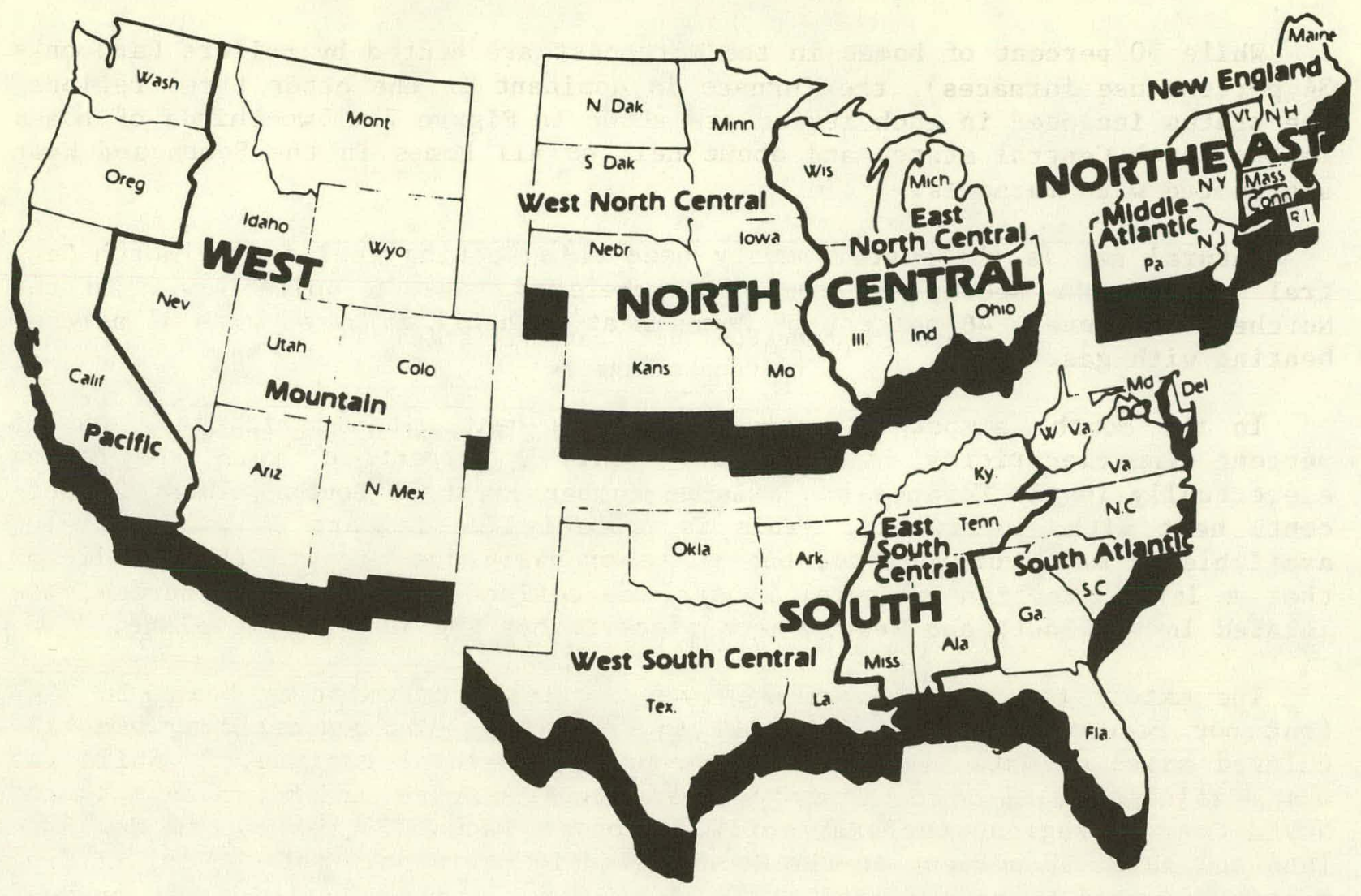

Figure 7. U.S. Census Regions and Divisions.

Table 10. Availability of Natural Gas to Households, 1981

\begin{tabular}{lccc}
\hline $\begin{array}{l}\text { Census Regions } \\
\text { and Divisions }\end{array}$ & $\begin{array}{c}\text { Total Households } \\
\text { (Millions) }\end{array}$ & $\begin{array}{c}\text { Gas Available } \\
\text { (Millions) }\end{array}$ & $\begin{array}{c}\text { Gas Available } \\
\text { (Percent) }\end{array}$ \\
\hline United States & 83.1 & 63.3 & 76.2 \\
Northeast & 17.9 & 13.4 & 74.9 \\
$\quad$ New England & 4.3 & 2.7 & 62.8 \\
Middle Atlantic & 13.7 & 10.8 & 78.8 \\
North Central & 21.2 & 17.9 & 84.4 \\
E. North Central & 14.6 & 12.7 & 87.0 \\
W. North Central & 6.6 & 5.1 & 77.3 \\
South & 27.7 & 17.7 & 63.9 \\
South Atlantic & 14.1 & 7.0 & 49.6 \\
E. Snuth Central & 5.6 & 3.6 & 88.3 \\
W. South Central & 8.0 & 7.1 & 87.7 \\
West & 16.3 & 14.3 & 90.0 \\
Mountain & 4.0 & 3.6 & 87.8 \\
Pacific & 12.3 & 10.8 & \\
\end{tabular}

Source: Reference 30 


\begin{tabular}{|c|c|c|c|c|c|}
\hline & Water Heating & $\begin{array}{l}\text { Table } 11 \\
\text { Fuel Use Char } \\
\text { Census Region }\end{array}$ & $\begin{array}{l}\text { racteristics } \\
\text { ns }\end{array}$ & & \\
\hline Water Heating Fuel & $\begin{array}{l}\text { Millions } \\
\text { Total }\end{array}$ & $\begin{array}{l}\text { of Households } \\
\text { Northeast }\end{array}$ & $\begin{array}{l}\text { and Percent } \\
\text { North } \\
\text { Central }\end{array}$ & of Househo & West \\
\hline Natural Gas & $\begin{array}{c}44.1 \\
(54.0 \%)\end{array}$ & $\begin{array}{c}7.2 \\
(40.7 \%)\end{array}$ & $\begin{array}{l}14.4 \\
(68.2 \%)\end{array}$ & $\begin{array}{l}11.3 \\
(41.9 \%)\end{array}$ & $\begin{array}{l}11.3 \\
(70.6 \%)\end{array}$ \\
\hline Electricity & $\begin{array}{c}26.1 \\
(32.0 \%)\end{array}$ & $\begin{array}{c}3.9 \\
(22.0 \%)\end{array}$ & $\begin{array}{c}5.2 \\
(24.6 \%)\end{array}$ & $\begin{array}{l}13.2 \\
(48.9 \%)\end{array}$ & $\begin{array}{c}3.8 \\
(23.7 \%)\end{array}$ \\
\hline Fuel Oil or Kerosene & $\begin{array}{l}7.1 \\
(8.7 \%)\end{array}$ & $\begin{array}{c}6.1 \\
(34.5 \%)\end{array}$ & $(0.9 \%)$ & $(3.0 \%)$ & -- \\
\hline LP Gas & $\begin{array}{l}3.6 \\
(4.4 \%)\end{array}$ & $(1.83 \%)$ & $\left(\begin{array}{l}1.2 \\
5.7 \%)\end{array}\right.$ & $\begin{array}{l}1.3 \\
(4.8 \%)\end{array}$ & $(4.7 \%)$ \\
\hline Wond & $(0.5 \%)$ & $(0.6 \%)$ & - & $(0.7 \%)$ & -- \\
\hline Solar & $(0.1 \%)$ & -- & -- & -- & $(0.6 \%)$ \\
\hline Other & $(0.1 \%)$ & -- & -- & -- & -- \\
\hline None & $(0.4 \%)$ & -- & -- & $\begin{array}{c}.2 \\
(0.7 \%) \\
\end{array}$ & $\begin{array}{l}-- \\
\end{array}$ \\
\hline Total Households & $\begin{array}{c}81.6 \\
(100 \%)\end{array}$ & $\begin{array}{r}17.7 \\
(100 \%)\end{array}$ & $\begin{array}{c}21.1 \\
(100 \%)\end{array}$ & $\begin{array}{c}27.0 \\
(100 \%)\end{array}$ & $\begin{array}{c}16.0 \\
(100 \%)\end{array}$ \\
\hline
\end{tabular}

Note: Rows and columns may not sum due to rounding.

Source: Reference 29 
used in about $54 \%$ of homes nationally, followed by electricity ( $32 \%$ ), fuel oil or kerosene $(8.7 \%)$ and LP gas $(4.4 \%)$. The fuel use varies from region to region. In the Northeast, a smaller percentage of homes heat water with gas or electricity, and about a third use oil. Electricity is the most common source in the South, and gas (including LP gas) is dominant in the North Central and Western regions. The use of oil for heating water is largely confined to the Northeast.

\section{Gas-Fired Storage Water Heaters}

The mainstay of the water heater industry is the glass-lined gas water heater with a baffled center flue. About 2.5 million units are produced each year for new construction and as replacements. Residential sizes range from 30 gallons to over 100 gallons. The burner input typically ranges from 30,000 to 50,000 Btu/hour. Generally, the smaller the tank, the smaller the input. Thus, it is common that a 30-gallon tank will have a $30,000 \mathrm{Bt} /$ hour 1nput, whereas a 40-gallon tank will have a 40,000 Btu/hour burner. However, a "premium" water heater will have a larger burner relative to the size of the tank. The lower burner inputs generally correspond to "economy" models, or "conservationist" units. 31

Energy losses include heat lost up the flue with the combustion products, heat lost up the flue when the burner is not operating, including pilot light heat, and, heat continually lost to the heater's surroundings through the jacket. The "recovery efficiency," which is the percentage of energy put into the water compared to the energy used by the heater, is typically in the 70-80 percent range. The "energy factor," which is a measure of the daily useful hot water Btu output divided by the gas energy consumed, is lowered to an average of only about 50 percent, due to standby losses.

Most manufacturers have introduced new, more efficient lines. The basic approach has been to improve the efficiency of conventional designs as opposed to any radical changes in the design concept. Recovery efficiency is improved by reducing burner input and increasing flue baffling. Standby losses are reduced by reducing the pilot burner input and increasing the amount of jacket insulation. 31

The Federal Trade Commission (FTC) requires that gas, electric and oil storage water heaters be labeled to show: (1) an estimated annual cust of operation for that particular model (based on a standard water usage rate and a national average fuel cost specified by FTC), and (2) how the efficiency of that model compares to that of all other comparable models. The label also shows the "first hour rating," which is the number of gallons of hot water that the unit can supply in one hour of operation. It depends on the size of the tank and the rate of heat input from the burner. The first hour rating ranges from about one to about two times the tank capacity. The ratings displayed on the label result from a test performed by the manufacturer in accordance with the U.S. Department of Energy's standardized rest procedure. 21

The Gas Appliance Manufacturers Assocation (GAMA) has a program for certification of water heater efficiencies through independent testing on a random 
basis, The results are published in a directory which is printed twice a year. 20 It is intended to assist dealers in selling, and the consumer in selecting, the best water heater buy. The directory lists not only units supplied by natural gas and propane, but also oil-fired water heaters, electric water heaters, and heat pump water heaters.

\section{0i1-Fired Storage Water Heaters}

Oil-fired storage water heaters are similar to gas-fired units except that a standard oil burner is used instead of a gas burner. Their energy input rates, however, tend to be higher. Whereas many gas units have inputs of $30,000 \mathrm{Btu} / \mathrm{hour}$ and even less, the lowest input for oil heaters is about $70,000 \mathrm{Btu} /$ hour. This corresponds to the smallest practical oil burner nozzle size (to avoid clogging), which flows $1 / 2$ gallon of oil per hour. The energy factors are about the same as, or slightly higher than, those for gas heaters. The high input rate permits achieving the same first hour rating $\mathbf{a s}$ a gas heater with a smaller tank siz.e.

0il-fired water heaters cost more than gas-fired water heaters, primarily because the ofl burner is n more expensive component than a gas buruer.

\section{Electric Storage Water Heaters}

The electric storage water heater is basically an insulated glass-lined tank with resistance heating elements immersed dirertly in the water to bc heated. There are, of course, no flue losses. All of the energy in the electricity supplied is transferred to the water. The losses are primarily standby losses, due to transfer of heat through the jacket to the surroundings. For most models, the energy factor falls in a range of 65 to 95 percent. The more efficient models have more effective insulatinn and "heat traps" on both the hot and cold water lines to reduce conductive heat losses.

Standby losses are defined as the percentage of heat lost from the stored water per hour compared to the heat content of the stored water, under the test conditions set hy DOE. For electric water heaters they range from a low of about 0.6 percent to a high of about 3.4 percent. This corresponds to a daily loss of from 14 percent to over 80 percent of the heat content of the water.

\section{Instantaneous Water Heaters}

Systems are available in which high output gas or electric heaters heat water only when it is needed, on demand. Appliances of this type, which are popular in Europe and Japan, are generally called instantaneous or point of use water heaters.

There are three principal ways in which instantaneous water heaters can be used. The first is to install a high capacity unit in a central location to supply all appliances and hot water outlets in the house. Piping runs should be short for satisfactory performance. The second is to install several small point-of-use units at various locations. A third approach is to use a conventional storage water heater with a single instantaneous gas or electric heater at the dishwasher and/or clothes washer. The storage heater temperature can 
then be lowered to around $110-120^{\circ} \mathrm{F}$, at which temperature its standby losses are reduced. The booster heater raises the water temperature to about $140^{\circ} \mathrm{F}$ for only those uses that require very hot water. Articles on these instantaneous water heaters, which are now being marketed by several firms in this country, have appeared recently in several magazines. 32,33

Instantaneous gas-fired water heaters with enough capacity to be used centrally in a house are available from Controlled Energy Corp., Waitsfield, VT, ITS Corp.. Englewood, CO., Paloma Industries, Bensonville, IL, and Tankless Heater Corp., Greenwich, CT. They sell for about $\$ 600-\$ 800$ at retail but have relatively low operating costs, since no water is stored. These units require a flue.

When conventional storage water heaters are used in a home, water for a bath is typically drawn at a mixed temperature of $100-110^{\circ} \mathrm{F}$ and at a flow rate of 2-3 gallons per minute. Gas-fired instantaneous water heaters with this capacity require a firing rate of about $100,000 \mathrm{Btu} / \mathrm{hour}$. If water is required at $140^{\circ} \mathrm{F}$ (for a dishwasher) at a $90^{\circ} \mathrm{F}$ rise, the flow rate would have to be restricted to about 0.8 gallons per minute.

Electric instantaneous water heaters are generally limited to point of use installations in houses because their capacity is relatively low. Special 220 volt wiring will usually be required because of the large power draw. (Heating 2 gallons per minute through only a $50^{\circ} \mathrm{F}$ temperature rise requires over 13 kW.)

\section{Heat Pump Water Heaters}

The heat pump water heater (HPWH) is a relatively new technology that is expected to compete very favorably with electric resistance water heaters and possibly oil-fired water heaters in many parts of the country. The HPWH works like a room air conditioner, except that it pumps heat from a room, basement or garage into a water tank rather than exhausting it outdoors. 34

Most HPWH systems are split systems in which the storage tank and heat pump are separate units connected by hoses. Integral type HPWH models have the condenser located inside the water storage tank. The tank is usually a standard electric water heater tank which has a hole in the top to allow insertion of a cylindrical shaped condenser. The condenser has a dual tube construction, or equivalent, to provide double separation between the refrigerant and the potable water. 34

The performance of the HPWH is determined by many factors, including its location in the house (in a heated or non-heated space). It provides a benefit in terms of cooling and dehumidifying the surrounding space, which is more important in warm climates than moderate climates. The following discussion of performance is taken from reference 34, a brochure on the HPWH prepared by Oak Ridge National Laboratory (ORNL). 
"Performance of a heat pump water heater varies with ambient temperature, supply water temperature, and delivery water temperature. In addition, withdrawal of water affects the temperature of the water in contact with the condenser and, thus, also affects performance. Nevertheless, heat pump water heaters can be expected to save 40 to $60 \%$ of the energy required for resistance water heating in many locations. Unheated rooms having waste or unused heat, rooms needing humidification, and rooms that would benefit from space cooling are good locations to install heat pump water heaters. Thus, utility rooms or conditioned space in the South and furnace rooms or unheated hasements in the North are examples of suitable applications.

Savings for unito located in condiliuned space are difficult to estimate closely because of the interrelationship between the unit and the space conditioning system. Heat extracted from the ambient air will affect the space conditioning system--adding to the heat load during the heating season, but assisting in cooling during the cooling season. Thus, the overall effert depends on the kind of space conditioning system. If space conditioning is provided by a heat pump, factoring in the differential space conditioning energy requirement results in a small degradation in cold climates and a small improvement in warm climates. Estimates of sayings from using a heat pump water heater rather than a rcoistance water liedLer in a representative, hcat pump conditioned hume have been made ful a varlecy of climates using the avallable laboratory data. Although these estimates can be improved as better data are obtained, they indicate generally what should be expected. IInder current conditions, installing heat pump water healiss in space conditioned with gas or oil heat may not be a good application. Similarly, if space heating is by resistance heat, only homes with long cooling seasons would be appropriate for heat pump water heater installation inside the conditioncd space."

The comparative annual operating costs for the HPWH and other means of heating domestic hot water, presented earlier in Table 8 , are based on more recent analysis by ORNL. 22 
Manufacturers of HPWH products appear to be concentrating their sales efforts at present in the Northeast, Southeast, and West, in areas where electric rates are high or where natural gas is not readily available. They include E-Tech, Atlanta, GA, Fedders, Emerson, NJ, Energy Utilization Systems, Pittsburgh, PA, Mor-Flo Industries, Cleveland, $\mathrm{OH}$, Northrup, Inc., Hutchins, TX, Heat Controller, Inc., Jackson, MI, Carrier Air Conditioning Co., Syracuse, NY.

\section{Solar Water Heating}

Solar hot water systems are generally sized to contribute from 40 to 80 percent of a house's needs for domestic hot water. The most accepted systems for use in cold climates are of the pumped circulating type using collectors with metal frames, glass covers, absorbers with copper tubing, a pump, a storage tank and a controller.35 Water flows from the storage tank to a conventional gas or electric water heater. The solar system can be considered as a preheater for a conventional water heater. Alternatively, electric resistance heaters can be installed in the solar system's storage tank, but this must be done in a way that avoids degrading the solar collector performance, which would occur iff the temperature of the water supplied to the collector were increased. 36

Systems of the type described above have an installed cost in the range of $\$ 3,500$ to $\$ 4,500.35$ A 40-percent federal income tax credit reduces the cost to $\$ 2,100$ to $\$ 2,700$ if the system is installed before the end of 1985 . Some other systems are available at somewhat lower cost. Also, some states offer state tax credits which supplement the federal credit.

Solar water heaters can be unreliable if not properly sized and installed. However, with proper sizing and component selection, and careful attention to every detail during installation, today's solar water heaters are considered to be fully capable of providing reliable, long-term service. 35

As indicated earlier in this report, the annual cost of nonsolar domestic hot water, for average water usage, ranges from about $\$ 200$ to $\$ 500$ per year, depending on the system used and fuel prices. If a solar system provides 60 percent of the DHW demand, and costs in the area of $\$ 2,000$ to $\$ 2,500$ after tax credits, it is clear that the payback period is very long, no less than seven years and in some cases well over 10 years. IL becuües more attractivc, of course, if a high rate of escalation of fossil fuel prices and electric rates is expected to occur in future years.

\section{Integrated Space Heating and Domestic Hot Water Systems}

There are several ways in which both space heating and DHW heating can be provided by a single appliance or system. A classification of such systems is provided in Table 12 .

The most common integrated system is a boiler which supplies hot water for space heating and also provides DHW through use of a "tankless coil" which is immersed in the boiler water. When hot water is demanded (by opening a sink 
Table 12

Classification of Integrated Space Heating and Domestic Hot Water Systems

\begin{tabular}{|c|c|c|c|}
\hline DHW Heating & DHW Storage & Description & Remarks \\
\hline \multirow[t]{2}{*}{$\begin{array}{l}\text { Direct ( DHW is } \\
\text { heated within } \\
\text { the botler: }\end{array}$} & $\begin{array}{l}\text { No } \\
\text { of t.orage } \\
\text { DH'N }\end{array}$ & Tankless coil in conventional boiler. & $\begin{array}{l}\text { Available as an option from most } \\
\text { boizer manufacturers. Used } \\
\text { prinarily with oil-fired boilers. }\end{array}$ \\
\hline & DHW is Srored & $\begin{array}{l}\text { Conventional DHW storage tank serves } \\
\text { as external extension to tankless } \\
\text { coil in conventional boiler. Small } \\
\text { circulating pump is used to circulate } \\
\text { DHW from coil to tank and return. } \\
\text { DHW is drawn from storage tank on } \\
\text { denand. }\end{array}$ & $\begin{array}{l}\text { Js sally a custom installation, } \\
\text { witb tank and pump purchased } \\
\text { separately. Used primarily with } \\
\text { oil-fired boilers to increase } \\
\text { gmount of DHW available. }\end{array}$ \\
\hline \multirow[t]{3}{*}{$\begin{array}{l}\text { Indirect (LitW is } \\
\text { heated outside } \\
\text { of the boiler) }\end{array}$} & $\begin{array}{l}\text { No Storage of } \\
\text { DHW }\end{array}$ & $\begin{array}{l}\text { Hot }\left(170^{\circ} \mathrm{F}\right) \text { water from low-mass } \\
\text { boiler circulates through an external } \\
\text { tank which is connected like an } \\
\text { additional zone in a hydronic heating } \\
\text { system. DHW flows on demand through } \\
\text { a coil in the tank; DHW temperature } \\
\text { is thermostatically controlled. }\end{array}$ & $\begin{array}{l}\text { Example: Potterton/Enerquip, Inc. } \\
\text { "Nətaheat } 80 " \text { (Gas-fired). } \\
\text { No chimney required. Over } 300,000 \\
\text { in use in England. U.S. licensee. }\end{array}$ \\
\hline & \multirow[t]{2}{*}{$\mathrm{DHW}$ is Stored } & $\begin{array}{l}\text { Low mass boiler transfers heat to a } \\
\text { separate DFW storage tank using a } \\
\text { heat exchanger external to both the } \\
\text { boiler and the tank. Connections are } \\
\text { made as with a separate hydronic } \\
\text { heating zone. Boiler heat is purged } \\
\text { to last zone calling for heat after } \\
\text { each heat demand, and boiler becomes } \\
\text { cold. DHW is drawn from storage tank } \\
\text { on demand. }\end{array}$ & $\begin{array}{l}\text { Example: Energy Kinetics, Inc. } \\
\text { 'Systen 2000" (Oil- or gas-fired). } \\
\text { Microp=ocessor control is used to } \\
\text { select the "zone" to receive } \\
\text { puzged boiler heat. }\end{array}$ \\
\hline & & $\begin{array}{l}\text { Low-mass boller transfers heat to a } \\
\text { separate DHW storage tank using a } \\
\text { coll immersed in the DHW tank. } \\
\text { Connections are made as with a } \\
\text { separate hydronic zone. Boiler is } \\
\text { allowed to drop to low temperature } \\
\text { between heat calls. DHW is drawn on } \\
\text { demand directly from storage tank. }\end{array}$ & $\begin{array}{l}\text { Example: Circle Combustion Corp. } \\
\text { "Circle Combustion System". Riello } \\
\text { burner, Pensotti boiler, Amtrol } \\
\text { DHE tank (0il-fired). Micro- } \\
\text { processor control adjusts boiler } \\
\text { चater temperature in accordance } \\
\text { øith outside temperature. }\end{array}$ \\
\hline
\end{tabular}


faucet, for example), cold water flows through the coil, which is usually a serpentine length of finned copper tubing. When the water leaves the coil and flows to the faucet, it has been heated to a temperature around $120-140^{\circ} \mathrm{F}$. Initially, the hot water draw causes the boiler water temperature to fall. This causes the burner to come on in order to maintain the boiler water at a pre-selected temperature.

As with storage hot water heaters, the rate at which the tankless coil can supply hot water is limited. In practice, the coil is designed to have a sufficiently large surface area, the boiler is sized to contain a sufficient amount of hot water, the burner is provided with a sufficiently high firing rate (usually a higher rate than needed to meet the space heating needs of the house), and the boiler water temperature control is kept high enough, to provide hot water continuously at a reasonable flow rate.

The tankless coil is used widely in houses in the Northeast that are heated by oil-fired boilers. It has a considerably lower first cost than would be incurred to install a separate storage type water heater with its own oil burner. Provisions are made in some gas-fired bollers for installation of a tankless coil. In practice, however, this option is seldom used. Most gas heated homes have a separate gas-fired storage water heater. Gas water heaters are relatively low in cost. It probably costs no more (or little more) to install a separate gas water heater and a gas boiler which is sized only for the space heating needs of the house. The boiler cost would be lowered because it would be smaller.

The simplicity and low cost of the tankless coil can be combined with a separate glass-lined storage tank which increases the availability of domestic hot water by maintaining a standby supply for use at all times. This permits use of a smaller boiler. Water is circulated by a small auxiliary pump through the tankless coil to the storage tank and back to the coil. A the rmostat on the tank permits simple adjustment of the stored water temperature over a range of about $120-160^{\circ} \mathrm{F}$. These tanks are offered in sizes ranging from 30 to 70 gallons by several manufacturers, including Mor-F1o Industries, Cleveland, $\mathrm{OH}$ and Aero Environmental Limited, Toronto, Ontario.

The two tankless coil systems described above produce DHW at high efficiency when the space heating load is high but the efficiency drops to about 25 percent or less in the summer, when all of the system's losses are chalgeable to DHW. The boiler must maintain a high water temperature at all times, to meet DHW demands.

New integrated systems are now available with higher efficiencies. They employ low mass boilers which contain only a few gallons of water. The DHW is heated indirectly, outside of the boiler, and the boiler water is not kept at a high temperature except when there is a demand for heat. Because of the low mass, the boiler water heats up in a matter of minutes when there is a call for space heat from one of the zones of the house or for DHW. Three systems of this general type are described in Table 12 .

While all of these integrated systems are boiler based, they can be used in a house with a forced air distribution system by adding a heat exchanger 
and blower, called a fan-coil unit. Two or more fan-coil units can be used to provide a zoned system, and air conditioning coils can also be installed in the ducts if desired. A boiler system of this type with a fan coil would probably have a higher first cost than a forced air furnace and separate water heater, but the cost increment might be recovered in a reasonably short period because of the high efficiency at which the system provides both domestic hot water and space heat. The cost recovery period would be shorter in houses with higher space heating loads and/or DHW demands. 37 


\section{SYSTEM SELECTION}

\section{A. Introduction}

Traditionally, the "best" heating system selection is one that provides the heating function at the lowest total owning and operating cost to the consumer. 38 This criterion remains valid for new, energy-efficient housing, but the selection is complicated by a need to redefine the "heating function" when considering these houses. Some designers of energy-efficient houses claim that their structures need no heating (using purchased energy) if the occupants will accept a relatively wide range of indoor temperatures, and are willing to use a wood stove on the few coldest days.

Definition of the best heating systems for these houses must take account of the need for air moving that is usually required for one or more reasons if an acceptable level of comfort is to be maintained. The means for providing air movement and heat transfer in the house should, in the author's opinion, be considered to be as important as, if not more important than, the selection of the source of whatever amount of auxiliary heat is required.

It is possible to design a house that is so energy efficient that the balance point temperature would be sufficiently low that, with provision for a moderate amount of thermal storage, no auxiliary heating would ever be required. Such a house would almost certainly not be cost effective, that is, the incremental cost of providing such a capability would be far greater than the savings in purchased heating energy. Therefore, as a practical matter, all reasonable energy-efficient houses will require some auxiliary heating. Not only will heating be required, but additional provisions will be needed, including appropriate controls, to maintain the interior spaces within generally acceptable ranges of comfort when the occupant so desires. Ventilation cooling will usually be required, and mechanical cooling (air conditioning) will of ten be required as well.

For purposes of this survey, it is also assumed that the level of comfort desired will be provided largely under automatic control, which has been the standard for comfort conditioning in most parts of this country for over 40 years. However, energy efficient houses tend to have large variations in load requirements in the bullding spaces. Fully automatic operation would of ten require a high degree of sophistication to enable the system to provide good temperature control, which would not be cost-effective. Therefore, the fo1lowing discussion and analysis is based on the assumption that systems should be capable of providing an acceptable basic level of performance under automatic control under most conditions, but that some interaction and control by occupants will of ten be required to maintain the higher level of comfort that they may desire. 


\section{B. Space Heating}

\section{Air Moving Needs}

The first step in system selection for a house with a low requirement for space heating is to analyze the design of the house to identify its special needs for air movement and heat transfer. Examples of such needs are listed below.

o Means to provide ventilation cooling in spring, summer, and fall.

- In houses with attached sunspaces, means to utilize hot air at the peak of the space in the winter and to remove it to the outdoors in warmer months.

- In houses with large amounts of south-facing glass, means to transfer excess heat from south rooms to north rooms in the winter, rather than draw hlinds.

o In multi-story houses with open stairways, means to deal with overheating of the upper level due to gravity circulation and chimney effect.

- Means to move heat into and out of thermal storage features or devices, if included in the design.

- In superinsulated houses with very low air infiltration, means to provide ventilation to maintain acceptable indoor air quality.

Air movement is accomplished by electric-powered fans and blowers. Their energy consumption must be added to the energy used by the heating system and, if installed, by the air conditioning equipment, when assessing operating costs. It is important to have some feeling for the heat transfer that can be accomplished by air movement and the energy costs to provide that air movement :

Fig. 8 is a plot showing how much heat can be transported by fans of various capacities for a range of temperature differences, $i . e$. the temperature at the fan inlet minus the temperature in the space to which the warm air is being moved. Areas are marked to show the typical operating ranges of familiar types of air movers.

Area 1 represents the blowers in typical small forced air furnaces, which deliver about $500-1000 \mathrm{CFM}$ of air at a temperature of about $130-140^{\circ} \mathrm{F}$. When the air mixes with room air its temperature has dropped by about $70^{\circ} \mathrm{F}$. The heat transport is about $40,000-50,000 \mathrm{Btu} / \mathrm{hr}$.

Whole house fans, Area 2, deliver much more airflow, typically 4,000$10,000 \mathrm{CFM}$, but at a much smaller temperature difference. These fans typically move $80^{\circ} \mathrm{F}$ inside air to the outside. This air is replaccd by outside air at about $70^{\circ} \mathrm{F}$ which enters through selectively opened windows in the rooms to be cooled. The heat transport is in the range of $25,000-65,000 \mathrm{Btu} / \mathrm{hr}$ for these conditions. 
Houses with attached sunspaces often use fans to take hot air from the peak of the sunspace on sunny winter'days and move it to a basement or to some form of storage such as passages in the chimney, plastic tubes in the basement floor slab, or to a rockbed. Large amounts of heat must be moved even if the sunspace has high thermal storage capacity itself, if the room is to be kept at a comfortable temperature. About 22,000 Btu pass through each $100 \mathrm{sq}$. ft. of south-facing glass each hour at midday on clear winter days at $40^{\circ} \mathrm{F}$ north latitude. In the summer the same fan can be used to exhaust the sunspace air to the outside. These fans would operate in or near Area 3, moving 10,000$20,000 \mathrm{Btu} / \mathrm{hr}$ when the temperature difference is in the $8-20^{\circ} \mathrm{F}$ range.

Small fans are available for moving air from ceiling to floor in a room to reduce temperature stratification. Similar fans are sold for houses using wood stoves to move air from a warm room through an opening in a wall to an adjoining room. They are usually rated at only a few hundred CFM, and fall in Area 4. They move relatively little heat.

Very small fans are used for kitchen and bathroom ventilation, as shown in Areas 5 and 6 . These fans move heated house air to the outside in the winter, and thus add to the house heating load, but they remove only a small amount of heat when operating, and their use is intermittent.

Air-to-air heat exchangers, not shown in Fig. 8, should exhaust air at a rate to provide about $1 / 2$ air change per hour. This corresponds to about 100 CFM in a $1500 \mathrm{sq}$. ft. house. The heat transferred is not all lost, however, since up to about $70 \%$ is transfered to the incoming air in the heat exchanger.

The power required to drive a fan can be estimated by referring to Fig. 9, where fan power is expressed as a function of CFM and the pressure rise in the fan, expressed in terms of inches of water column (in. w.c.). A furnace blower with 800 CFM capacity operating against a duct system pressure of 0.5 in. w.c. would require .07-.14 HP ( $1 / 15$ to $1 / 7 \mathrm{HP}$ ) depending on the blower efficiency. Most blowers have efficiencies in the range of 50-80 percent. If the efficiency were $65 \%$ the fan power would be .10 HP. If the electric motor driving the fan is $50 \%$ efficient a $1 / 4 \mathrm{HP}$ motor would be needed. The power draw would be $(.10 / .50) \times 746=149$ watts $(746$ watts $=1 \mathrm{HP})$.

Fans and blowers use relatively small amounts of electricity. However, under continuous operation, the electric power use can and up to a significant fraction of total heating and cooling energy costs. An efficient model should be selected when the fan will be in operation for long periods of time. Whenever a fan installation is planned, consideration should be given to providing a multi-speed or variable speed capability, since the loads tend to be variable. Operation at a low speed will often be adequate, and the fan will be quieter. Fan motors tend to be rather inefficient, particularly in small sizes in the $1 / 8$ to $1 / 4 \mathrm{HP}$ range where shaded pole motors are often used. A permanent-split capacitor motor is a lot more efficient than the shaded pole type, but usually has a higher price. ${ }^{39}$ Multi-speed motors are usually somewhat more efficient than motors with a continuously variable speed capability.

After evaluating the requirements for air movement, the next step is to determine the heating and cooling loads of the house, following the procedures 


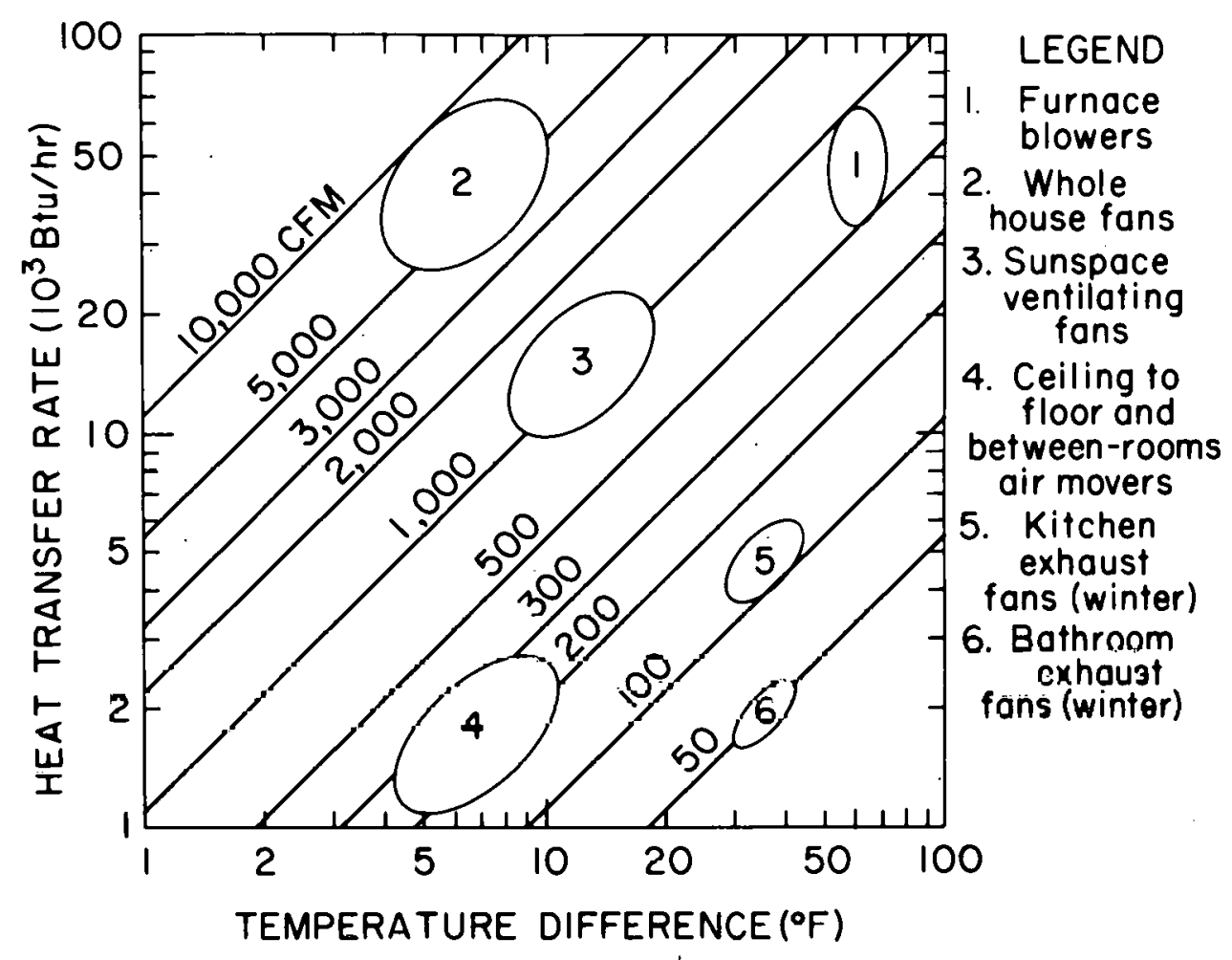

Figure 8. Air Flow Required to Transport Thermal Energy.

FAN EFFICIENCY $(\%)$

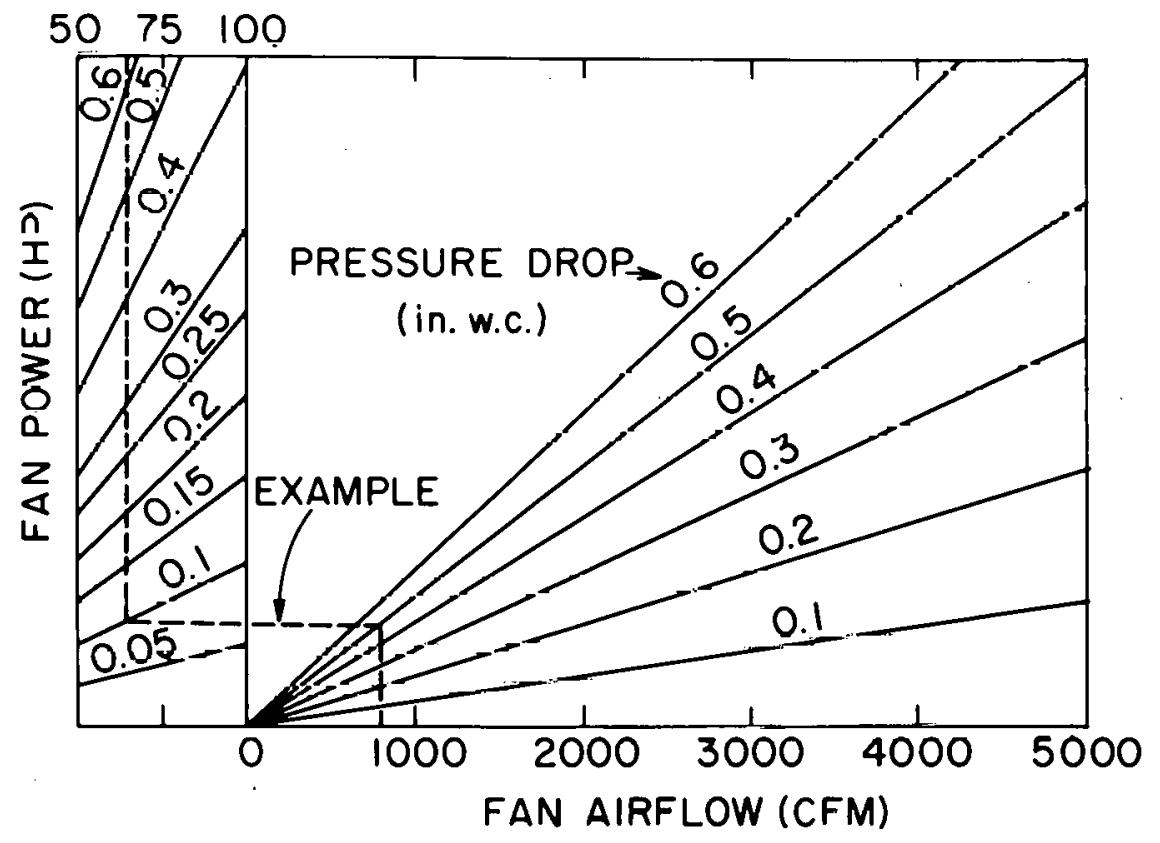

Figure 9. Power Required to Drive a Fan. 
in Chapters 25 and 26 of the ASHRAE Handbook Fundamentals Volume ${ }^{17}$ or in other reference manuals. Internal heat gains from occupants, appliances, and lighting can then be estimated. For residences, ASHRAE 17 recommends using 225 Btu/hr per occupant and an average kitchen appliance heat release of 1200 $\mathrm{Btu} / \mathrm{hr}$. For heating load analysis, an estimate of solar gain through southfacing glass in representative winter months can then be made using average solar radiation data from a guide such as ref. 36, with an approprite transmittance factor for the glazing employed. A simplified approach to estimating solar heating through windows will be found in reference 40 .

Relating the internal gains and solar gain to the heating load, as discussed in section III of this report, gives the heating balance point temperature for that particulir house and occupancy pattern. The balance point temperature provides a measure of the effectiveness of the building in maintaining comfortable indoor temperatures without need for auxiliary heating on days with solar radiation equal to the average for the period.

While a low balance point temperature results in a reduced need for heating, it also tends to result in an increased need for cooling, particularly ventilation cooling using outside air. This is illustrated in the graph in Fig. 10, which is an adaptation of a format originally presented in a report prepared at Lawrence Berkeley Laboratory. 41 The vertical scale is inside temperature and the horizontal scale is outside temperature. The dashed line represents a condition where the two temperatures are equal. A low balance point tends to move the inside temperature up at any given outside temperature, with no auxiliary heat. Building $C$, described in an earlier section, has a balance point temperature of $f$ set of about $12^{\circ} \mathrm{F}$. It is represented by a second diagonal line, $12^{\circ}$ above the first one.

The heavy line in Fig. 10 represents a possible pattern of inside temperature as the outside temperature ranges from $30^{\circ} \mathrm{F}$ to $90^{\circ} \mathrm{F}$. In cold weather, the inside temperature is kept at $68^{\circ} \mathrm{F}$ through use of auxiliary heating, as depicted by the shaded area. When the outside temperature. rises to $56^{\circ} \mathrm{F}$, auxiliary heating is no longer required.

As the outside temperature rises above $56^{\circ} \mathrm{F}$, the inside temperature also rises, on a degree for degree basis (but with some lag). At an outside temperature of $63^{\circ} \mathrm{F}$, the inside temperature would be about $75^{\circ} \mathrm{F}$, and it would rise to about $80^{\circ} \mathrm{F}$ when the outside temperature reached $68^{\circ} \mathrm{F}$. Occupants would be likely to open windows to reduce the internal temperature rise, but the effectiveness of open windows would be limited unless there was a breeze. It would be necessary to have some means of providing forced ventilation, when there is insufficient wind. As the outside temperature rises further, into the high $70 \mathrm{~s}$ and $80 \mathrm{~s}$, it might be necessary to use an air conditioner to keep the inside comfortable, as shown in the shaded area at the upper right of the figure.

Cooling with outside air would be useful in the central shaded area of Fig. 10. It can be accomplished at a much lower energy cost than mechanical air conditioning. The air movement caused by a fan which draws outside air into a house produces a sensation of comfort even though the indoor 


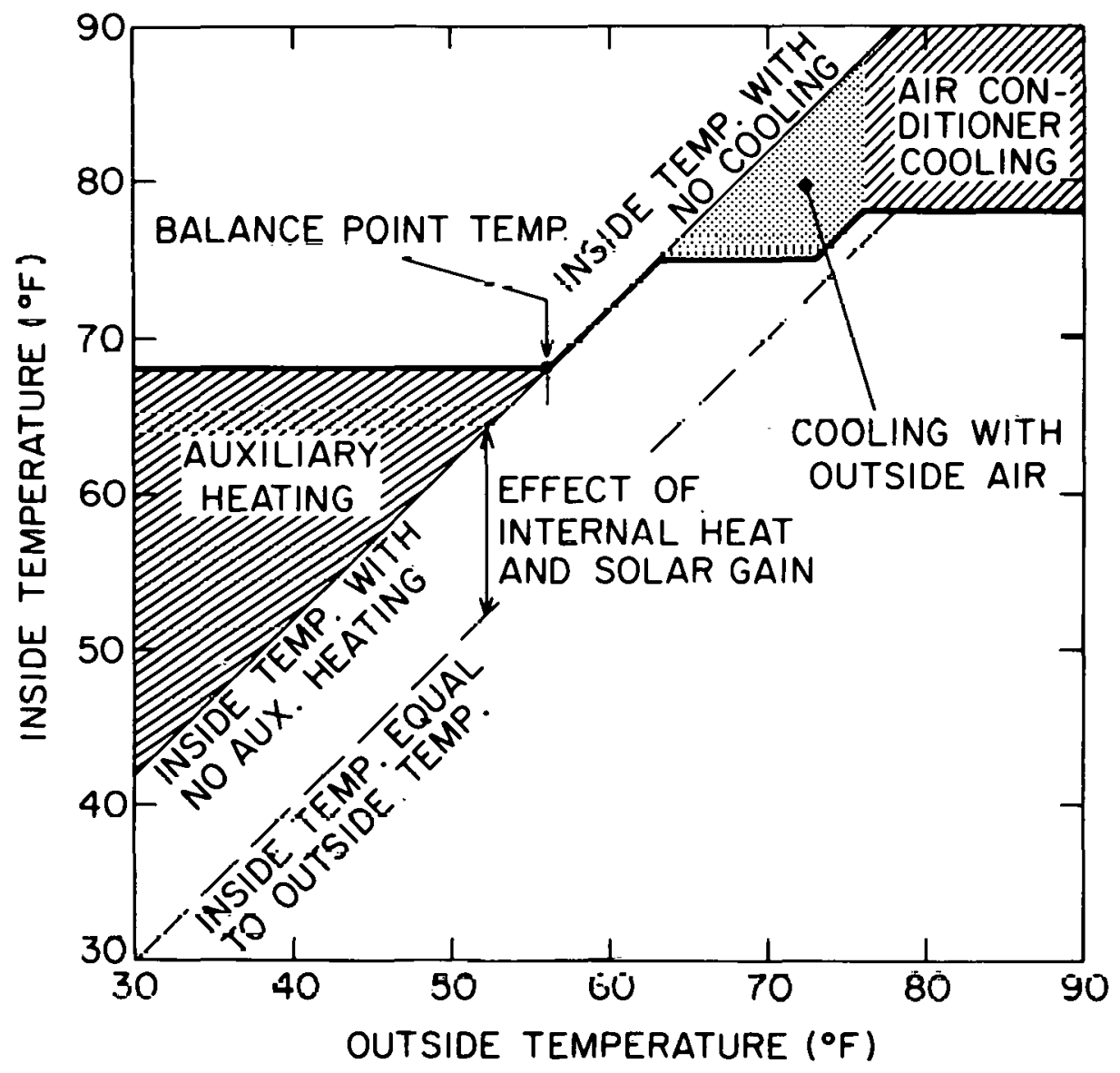

Figure 10. Auxiliary Healing and Cooling Requirements of Building C. 
temperature is above the normal comfort limit for still air. A 1/4 HP wholehouse fan, suitable for a $1,500 \mathrm{sq}$. $\mathrm{ft}$. house, uses only about $0.4 \mathrm{kWh}$ of electricity in an hour. A three-ton air conditioner consumes about $4 \mathrm{kWh}$ in an hour, or about 10 times as much as the fan (the actual air conditioner use will be somewhat lower, however, because the compressor normally cycles on and off).

The depiction of the area in Fig. 10 when cooling with outside air is appropriate is overly simplistic and requires elaboration. First, the $12^{\circ}$ offset of the balance point temperature for Building $C$ is associated with a combination of internal heat and solar gain. Closing drapes or blinds on south facing windows on sunny days would change the balance point and shift the point at which ventilation cooling begins to be needed to a higher outside temperature. Secondly, because of capacity for thermal storage in the house structure and furnishings, the rise of inside temperature lags behind the rise of outside temperature on warm days. Ventilation cooling with a whole house fan would normally not be used until evening when the outside temperature has fallen. When the fan is turned off during the night (by a timer or a thermostatic control), it will have cooled the mass of the house enough to delay the inside temperature rise on the following day.

The American Ventilation Association and the Home Ventilation Institute advocate use of whole-house ventilation at outdoor temperatures of $82^{\circ} \mathrm{F}$ and lower to produce comfortable indoor conditions. In a study conducted by the National Bureau of Standards, it was concluded that the whole house fan can be used as the major method of cooling in regions where monthly summer temperatures average $75^{\circ} \mathrm{F}$ or less, particularly when the outside humidity is not excessive. 42

\section{Distribution System Requirements.}

A house of conventional design, except for its very low heat losses, and with modest passive solar features, should normally be provided with a more or less conventional forced air distribution system for maximum comfort. Advantages of the forced air system include:

- Can supply heating or cooling.

- Provides mixing of air to eliminate stratification or local temperature extremes in some rooms.

- Can distribute dehumidified or humidified air.

o Can distribute controlled outside makeup ventilation air.

- Can interface with whole house nighttime ventilating system.

- Air filtration is standard with simple replaceable filters.

- Electronic air cleaners can be added if desired. 
- System provides desirable background sound level in a quiet, draftless home.

- Central heating can be provided using natural gas, propane, fuel oil, or electricity (resistance or heat pump).

This list is based in part on a paper prepared by a Minneapolis energy consultant, Martin R. Lunde. ${ }^{43}$ Another advantage cited by Lunde is the ability of the air distribution system to interface with supplementary heating using wood fuel. A return air grille located near the appliance draws heated air and distributes it throughout the house. In this mode of operation the furnace $f a n$ is turned on but the burner is not operated.

The duct system is the heart of a good forced air system. It requires careful design. For example, extra outlets may be required in the lower level of a multi-story house for good heat distribution. If air conditioning is provided by installing a split system with the evaporator in the ductwork, the duct sizes will have to be larger than if they are designed only for heating.

One disadvantage of forced air distribution is that zone control 15 not easily accomplished, though limited control is possible with manual room dampers. If the system is designed for year round comfort control, the owner of a two story home should be prepared to open additional outlets on the second floor in the cooling season and to close them in the heating season. 38 The second floor rooms need more air flow than those on the first floor when con.ling, but the reverse is true when heating.

In houses with attached sunspaces, a duct connection from the peak of the sunspace to one of the main system return ducts should be considered. On clear days in the heating season, the sunspace heat can be distributed throughout the house by the furnace blower. The furnace would rome nn only when the heat source is not sufficient to meet the heating needs of the house. This mode of operation requires opening of a door or louvers from the house to the sunspace to complete the circulating path.

The Lunde paper describes an interesting ducting system designed by his firm which combines a house ventllating capability with a forced air distribution system, as shown in Fig. 11. During the winter the system operates as a normal air system. The system's function is modified in the summer by positioning of three dampers and operation of an exhaust fan. Outside air pulled into the furnace by the furnace blower is distributed to all rooms via the regular supply ducts. The air is removed from the rooms through the return ducts, using an exhaust fan. This system would appear to be particularly effective in warm periods in spring and Fall in ventilating and cooling the house in the evening. It would not be as effective as a whole house fan in hot weather. However, its performance could approach that of the whole house fan by using a relatively large exhaust fan and opening some windows on a selective basis to provide additional airflow in excess of what the duct system is sized to handle.

The design of air distribution systems for energy conserving houses requires a degree of innovation and ingenuity to provide capability for all of 

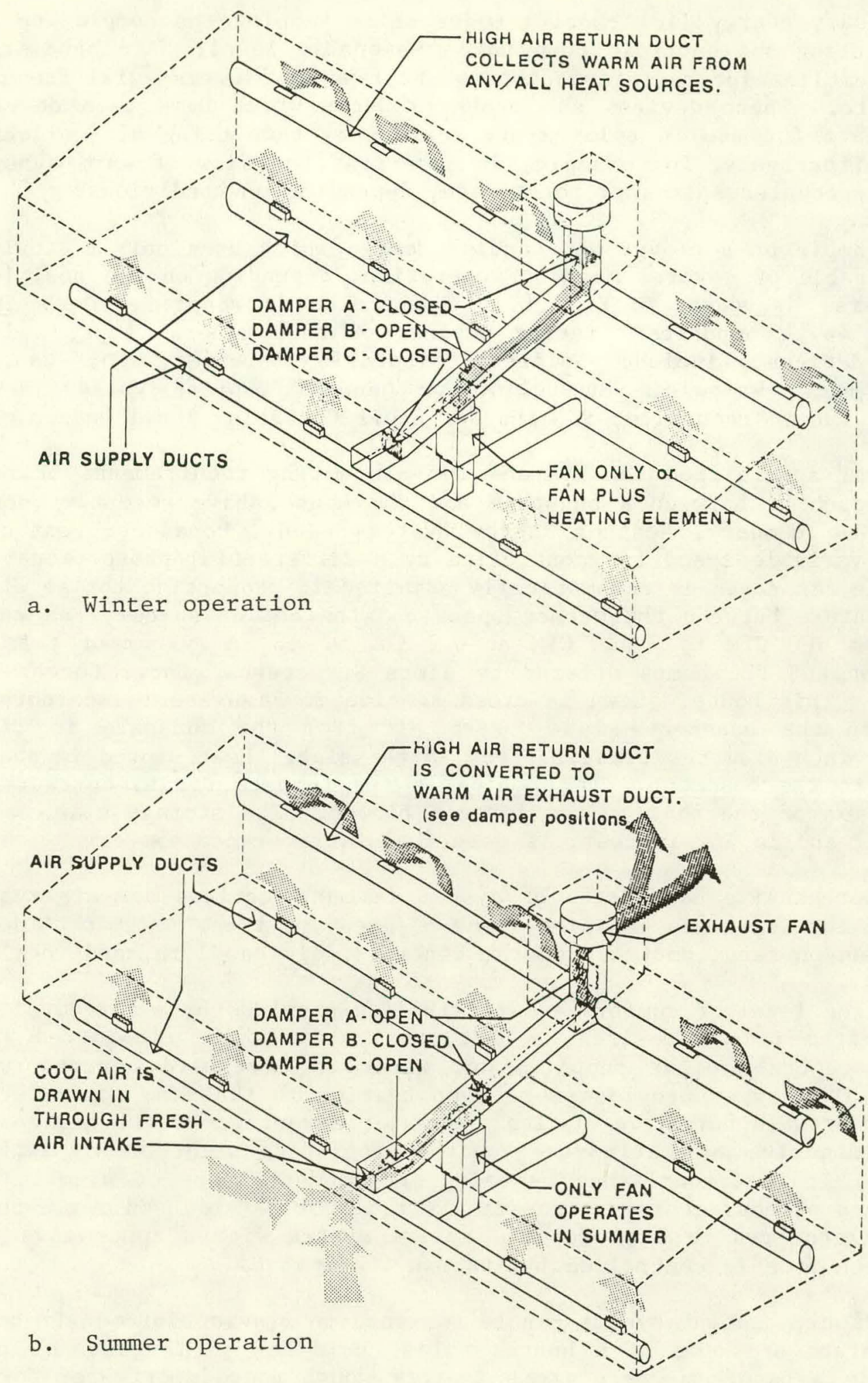

Figure 11. Forced Air Heating System with Ventilating Capability.

(Courtesy Martin R. Lunde and Associates, 1002 Wesley Temple Building, Minneapolis, MN 55403) 
the necessary energy flow control modes while keeping the complexity and cost of the ducting and controls down to a reasonable level. Air handlers--sheet metal assemblies incorporating dampers and fans or blowers--will frequently be appropriate. These devices and other products which have been developed in recent years for use in solar space heating systems using air collectors can be used effectively, for example, in directing the flow of warm sunspace air either to occupied spaces or to storage, depending on conditions.

An example of a clever air handler design which uses only a single blower but is capable of several modes of operation, depending on the positioning of its dampers, is shown in Fig. 12. The sketch is adapted from a figure in reference 44. Companies offering devices of this general type, and related control devices, include Solaron Corporation, Denver, CO; Contemporary Systems, Inc., Walpole, NH; Heliotrope General, Spring Valley, GA; Helio Thiesmics, Inc., Greenville, SC; and Hot Stuff Controls, Inc., LaJara, CO.

Several specialized fan systems for air moving requirements of new hnuse designs, such as between a sunspace and the house, have recently been introduced. One company, Weather Energy Systems, Inc., Pocasset, Massachusetts, offers a variable speed fan controlled by a differential/proportional thermostat. The fan speed is automatically adjusted in proportion to the difference in temperature between the warmer space and the cooler space. Fan capacities range from $600 \mathrm{CFM}$ to $3,410 \mathrm{CFM}$ at 0.2 in. w. c. A system of this type is used in one of the homes offered by Acorn Structures, Inc., Concord, Massachusetts. This house, shown in cross section in Figure 13, incorporates heat storage in the basement slab. Warm air from the sunspace is circulated through 4 inch diameter plastic pipes in the slab. Heat stored in the slab is released to the basement. An opening in the furnace return ductwork permits distribution of the heat by the furnace blower. The storage slab, which performs well and is low in cost, is described in reference 45.

A comprehensive discussion of system design practices for air systems appeared in the Solar Age magazine issue of January, 1983.46 It provides useful information on fans, ducts, dampers, controls, air handlers, and rock storage.

When the level of comfort and flexibility provided by a forced air distribution system is not desired, a hydronic system can be considered. In this system a central boiler supplies hot water to baseboard convectors in the rooms. 'l'he system provides more even heating in that the convectors rctain some heat between burner on cycles. A major advantage of the hydronic system is that effective automatic zone control, including night or day setbacks, is possible. It is accomplished by using independent loops of plumbing to connect groups of convectors. A separate circulator can be used for each zulle or one circulator can be used for the entire system with a zone valve for cach zone. Each zone is controlled by its nwn thermostat.

A hydronic heating system can be designed to provide forced air heating in certain areas or rooms of a house. This could be useful in some instances, such as in a bathroom where there is not enough unused perimetcr for the required length of baseboard convector. It is accomplished by use of fan-coil units, consisting of a water to air heat exchanger and a fan. The units can be located in a wall or in the kick space below a cabinet. 


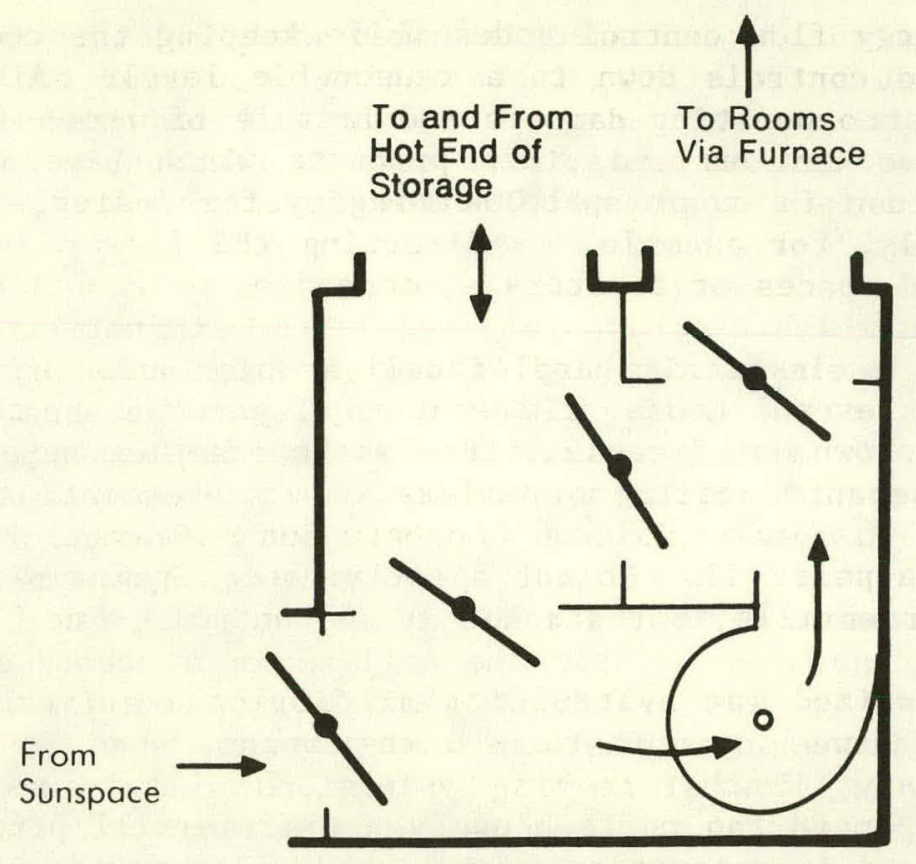

Figure 12. Single Blower Air Handler.

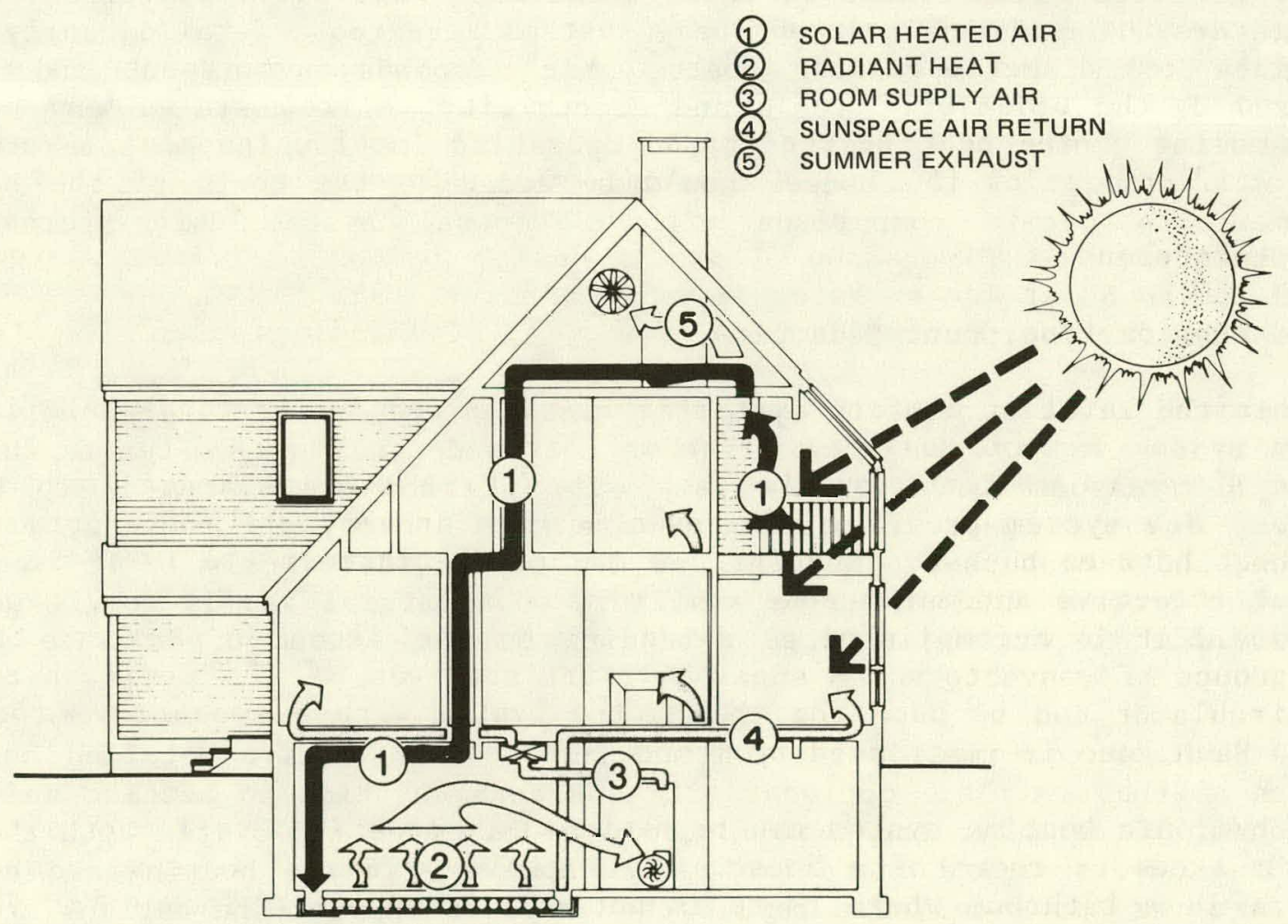

Figure 13. Acorn Structures, Inc. Isolated Sunspace House. 
Summer cooling can be provided in homes with hydronic heating systems at moderate first cost by selective installation of one or two through the wall high efficiency air conditioners. A common rule of thumb for capacity is 1 ton for each $500 \mathrm{sq}$. ft. of house. The rule is reasonable for older homes but should be modified to 1 ton per $1,000 \mathrm{sq}$. ft. for modern, well-designed and quality-built homes. 47

A third option which can be considered is to eliminate the need for a distribution system by installing individual heating units in each room or in certain open areas of the house. It will usually be necessary to augment such systems with some air moving capability. As an example, superinsulated houses with electric baseboard heating often experience overheating of the upstairs rooms if there is an open staircase due to gravity convection. Even if a door at the head of the stairs is closed, stratification takes place from floor to ceiling in each room. It is desirable to use a small fan (100 CFM or so) to pull warm air through a grill near the ceiling in a sernnt flnnr hallway and move it down through a vertical duct to an nutlet at a low level on the first floor. If significant solar features are present, such as a sunspace, more elaborate and higher flow air moving provisions will be required. In addition, provisions for forced whole house ventilation will often be required in the cooling season and at times in Spring and Fall.

Individual room or area heating sources can take several forms, as discussed in Section $V$ of this report. These include electric resistance baseboard, electric radiant panels, through-the-wall heat pumps and direct vented gas heaters. The choice between these systems requires a detailed analysis of installed costs and operating costs, which depends on present and future prices and availability of fuels and electricity. The costs of any special air handling equipment (first cost and operating cost) which must be provided to meet the needs of the house should be added to the costs of the heating equipment to permit comparison with a central system using forced air dictribution.

\section{Heating Equipment Selection}

A forced air distribution system is required when central air conditioning is desired. Even if central cooling is not needed, it will of ten be the best choice for reasons discussed earlier. If a forced air system is to be installed, a choice must be made hetween a gas furnace, oil furnace, eleclric furnace, and a heat pump. Natural gas can be considered only if it is available, but propane will often be available when natural gas is not. Fuel oil is available to varying degrees depending on the extent of its use in the area.

The heating equipment selection and fuel choice require detailed analysis of each of the available options, with due consideration to heating and cooling loads. Generally, the choice should be based on the system with the lowest total ownership and operating cost. However, if the heating and cooling loads are very low, and as a result the costs of many of the uptions are low, and the differences between their costs are small, other factors should be considered. These would include the level of comfort provided by the system above what might be considered a minimum level. 
When selecting gas or oil furnaces, high efficiency modern units should be considered. The blower should be capable of two-speed or even three-speed operation, and the controls should permit operation with the burner of $f$ so that air circulation can be used when desired to achieve uniform temperatures throughout the house, without heating. Ultra high efficiency furnaces, such as pulse combustion units, will probably not pay back their cost differentials soon enough to be economical in houses with low heating requirements. Some new gas furnaces with induced draft fans not only have high AFUE ratings but can be directly vented through a wall, saving the cost of a chimney. New gas furnaces with low output ratings in the range of 20,000 to $40,000 \mathrm{Btu} / \mathrm{hr}$ should be considered, to match more closely the design heating loads of the house.

A boiler is normally used with a hydronic (hot water) distribution system, but it can also supply the heat for a forced warm air distribution system through use of one or more fan coil units. The new low mass boilers are attractive for energy-efficient houses because of their high part load eficiency and the high efficiency at which DHW is provided. A conventional boiler with tankless coil is probably not a good choice for energy-efficient houses because of the low part load efficiency of space heating and the low efficiency of DHW heating in the warmer months.

Tables are provided in the Appendix which permit estimation of the cost to deliver one million Btu of space heat using various energy sources, various energy prices, and various types of heating equipment. The first covers oil and gas fired furnaces and boilers, the second covers electric resistance heating, and the third covers electric heat pumps.

\section{Domestic Hot Water Heating.}

The preferred system for heating domestic hot water should be selected after the space heating fuels and equipment are identified. If electricity is selected for space heating, an electric resistance or heat pump water heater will usually be the lowest life cycle cost choice because most electric utilities give a lower $\mathrm{kWh}$ rate for al1-electric homes.

If gas space heating is selected, a gas water heater will usually be the best choice, but the more expensive heat pump water heater may compete in some cases (see Table 8).

If an oil furnace is selected, an oil-fired water heater should be compared to an electric resistance water heater and a heat pump water heater on the basis of total ownership cost (first cost, operating cost, and maintenance).

When an oil boiler is to be used for space heating, one of the new low mass boilers with a separate hot water tank should be considered. They deliver DHW at reasonably high efficiency at all times.

\section{Price Projections for Fuels and Electricity}

The Department of Energy has released new projections of energy prices through 1990 in 1ts 1982 Annual Encrgy Outlook. 48 The world oil price 
projections are substantially lower than those of a year ago due to recent events in world oil markets. Figure 14 shows the current oil price projections, in 1982 dollars per barrel. The projections discussed below are based on the middle world oil price projection.

The latest U.S. average wellhead price projections for natural gas from the DOE report are shown in Figure 15. The price rise is expected to steepen in 1985 when about half of the domestic gas production will be free of price controls. The rate of increase slows later in the decade, however, due to competition with petroleum products, particularly residual fuel oil.

The DOE projections of national average prices for residential purchases of various forms of energy are compared in Figure 16 and Table 13. The prices are in terms of constant 1982 dollars per million Btu. Distillate fuel (heating oil) and natural gas are expected to sell at comparable prices in the late elglilies. The price gap between narural gas and olcctricity is projecled lu narrow. The price of gas inrreases from about 25 percent uf lle price of electricity in 1980 to about 46 percent in 1990, on a Btu basis.

While the houses which are the subject of this report require relatively little space heat, and can therefore be heated at moderate cost at current prices, it is important to recognize that the real. prices of energy (in constant dollars) are expected to remain in an upward trend, as shown in Figure 16. Also, there are and will continue to be significant regional differences in the prices of natural gas, fuel oil and electricity which should be considered in.selecting the best space heating and DHW systems. The energy cost becomes more significant when the DHW and space heating needs are combined.

"Ihe latest DOE projections for regional natural gas prices for 1985 and 1990 are shown in Table 14. The prices are a composite of prices to al. sectors of the economy, not just the residential sector. They suggest that natural gas will continue to cost more in the Northeast than in other regions, but that the price differences between regions will nariuw somewhar in future years.

Table 15 shows the cost of supplying one million Btu of space heat based on the national average energy price projections for 1990 using various types of heating systems operating at typical conversion efficiencies. The costs range from $\$ 10.61$ for a propane furnacc or hoiler lu $\$ 18.36$ for electric resistance heat, per million Btu delivered. Natural gas, oil and propane have very comparable cusls. The electric heat pump energy cost is only moderately higher, even with the relatively low seasonal coefficient of performance (SCOP) of 1.5 expected in energy-efficient houses in cold climates. (See discussion of heat pumps in section $V-\Lambda$ of this report.) Electric resistance heating, however, costs about fifty to eighty percent more than the other options. These comparisons, as noted, are for projected national average energy prices. The comparisons for various regions will vary considerably, and require independent analysis. 


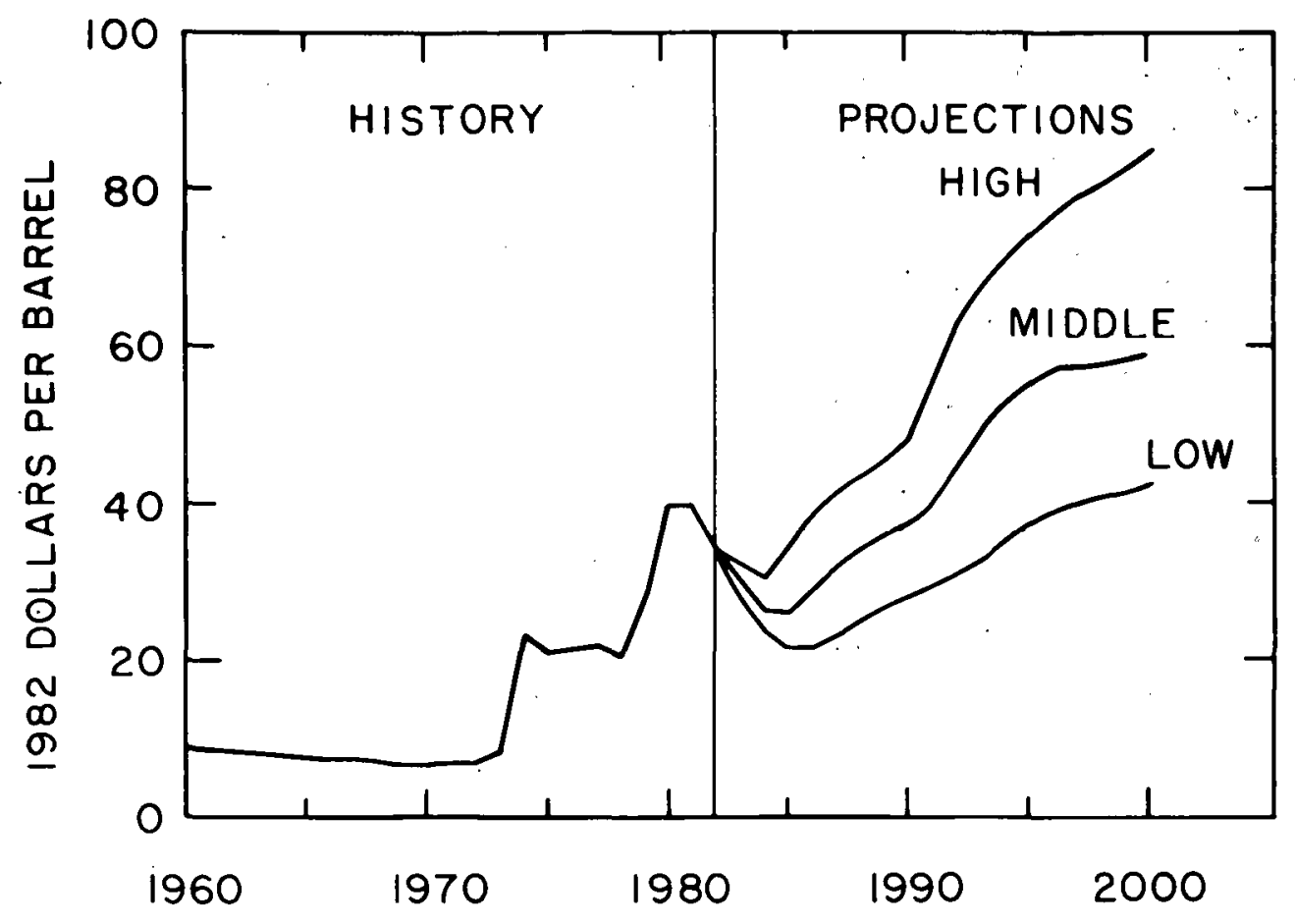

Figure 14. DOE/EIA World Oil Price Projections.

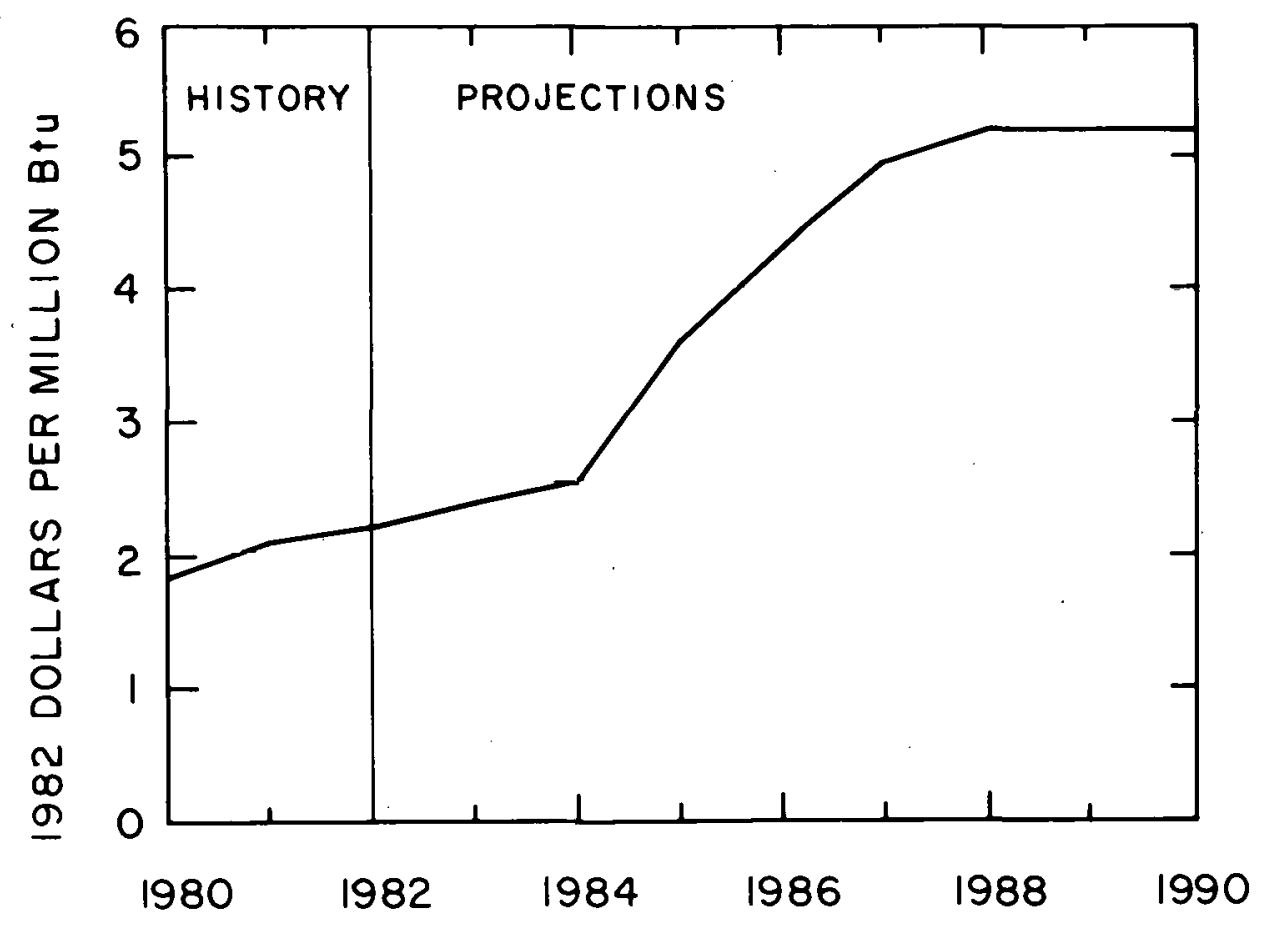

Figure 15. DOE/EIA Natural Gas Price Projections (U.S. Average Price, Midprice Scenario). 


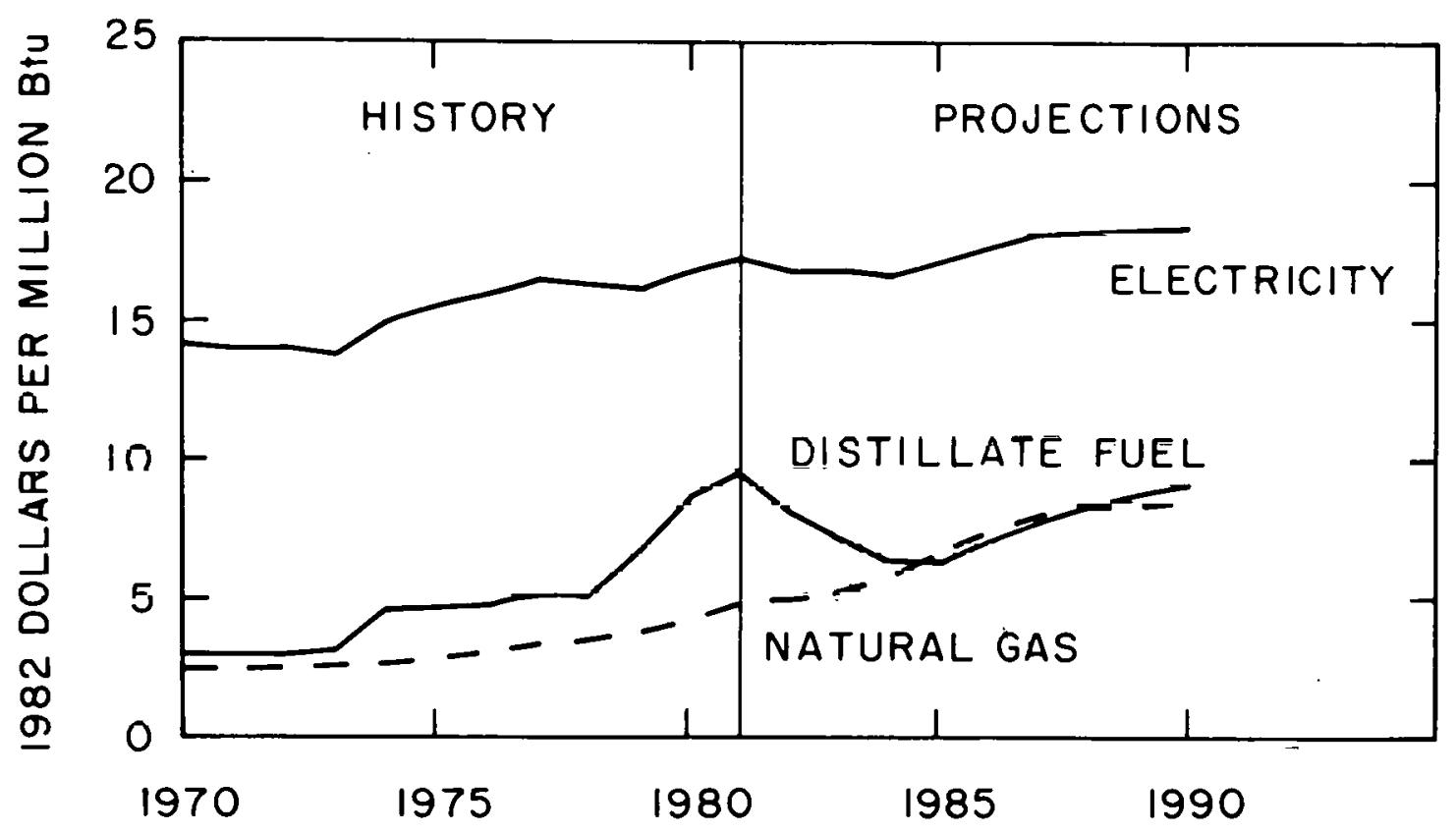

Figure 16. Average Residential Energy Prices (Midprice Scenario).

Table 13. Average Residential Energy Prices (Midprice Scenario)

\begin{tabular}{lcccc}
\hline & \multicolumn{4}{c}{1982 Dollars Pcr Million Btu } \\
\cline { 2 - 5 } Energy Form & 1975 & 1980 & 1985 & 1990 \\
\hline Natural Gas & 2.75 & 4.16 & 6.65 & 8.53 \\
Distillate 0il & 4.75 & 8.59 & 6.27 & 9.02 \\
LP Gas (Propane) & 4.11 & 6.67 & 6.04 & 8.49 \\
Electricity & 15.61 & 16.78 & 17.11 & 18.36 \\
\hline
\end{tabular}

Source: Reference 48 


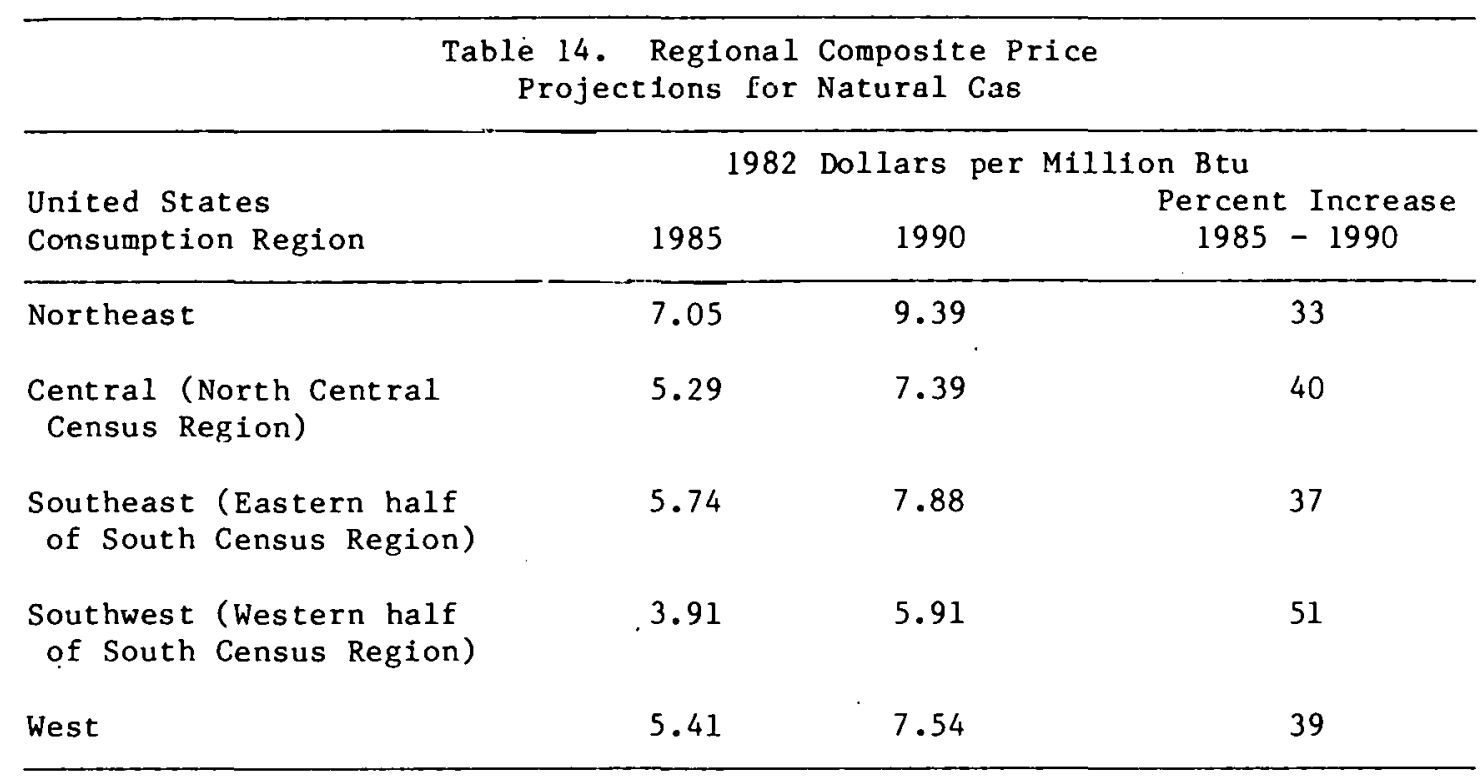

Source: Reference 49

Table 15. Projected 1990 Space Heating Costs per Million Btu of Heat Delivered (1982 Dollars)

\begin{tabular}{lccc}
\hline Heat Source & $\begin{array}{c}\text { Energy Cost } \\
\text { \$/Million Btu }\end{array}$ & $\begin{array}{c}\text { Conversion Effy. } \\
\text { or SCOP }\end{array}$ & $\begin{array}{c}\text { Heat Cost } \\
\text { \$/Million Btu }\end{array}$ \\
\hline Gas Furnace or Boiler & 8.53 & $80 \%$ & 10.67 \\
Oil Furnace or Boiler & 9.02 & $80 \%$ & 11.28 \\
Propane Furnace or Boiler & 8.49 & $80 \%$ & 10.61 \\
Electric Heat Pump & 18.36 & 1.5 & 12.24 \\
Electric Resistance & 18.36 & $100 \%$ & 18.36 \\
\hline
\end{tabular}

Source for energy costs: Reference 48 
There is a modest but increasing trend in new residential construction toward houses that have very low heating loads but are still relatively conventional in appearance and attractive to a large number of new home buyers. These houses have design (coldest day) heating loads in the colder climates in a range of only 10,000 to $20,000 \mathrm{Btu}$ per hour, as compared with 50,000 to $100,000 \mathrm{Btu}$ per hour for more conventional houses. Their annual heating requirements are typically from 5 to 50 million Btu, compared to 100 to 200 million Btu for houses of the same size built just before World War II. Their heating energy cost is in the range of only $\$ 100$ to $\$ 500$ per year, depending on the heating system and fuel prices, compared to $\$ 1,000$ to $\$ 1,500$ per year.

While these new building designs need only a small amount of energy for space heating, their energy needs for domestic hot water (DHW) are basically the same as in older houses, with an energy cost in the range of $\$ 150$ to $\$ 500$ per year. The approach to selection of the systems for providing space heat and DHW should take account of the fact that their energy needs are comparable, whereas the DHW load is only about a third of the space heating load in older houses of less efficient design. Because the DHW load has not been reduced, the combined space heat and DHW load still requires a significant amount of purchased energy. A careful approach should therefore be taken in selecting the systems to satisfy these loads.

The characteristics of new energy-efficient houses that result in low heating needs often require that increased attention be given to air moving in designing the house, if reasonable comfort levels are to be maintained in all seasons. The potential needs for air moving include ventilation, ventilation cooling, destratifaction of air in the house, transfer of incidental heat gains, and movement of heat to, and retrieval from, heat storage features. The incorporation of sufficient air moving capability in the house at moderate first cost and without undue complexity represents a challenge to designers of energy efficient buildings which often is not fully recognized until the house has been built and occupied and operational deficiences become apparent.

Many new products for space heating and DHW heating have come on the market in recent years, with higher efficiencies than traditional equipment. Some new control strategies have also been devised and demonstrated. The building designer should assess all of the options available before making system selections. Various ways of integrating the heating of DHW with the space heating function should be considered. Integration of the space heating equipment with the air moving needs of the house requires attention. The provisions for air conditioning, if required, also must be considered.

The best heating system for a new house has traditionally been the one that provides the heating function at the lowest total owning and operating cost to the consumer. This criterion remains valid for new, energy-efficient housing but the selection becomes complicated by the requirements for air moving and a need for greater control capabllities without introducing excessive complexity. 
Current forecasts of average prices for fuels and electricity for residential heating show a rough parity of prices for oil, natural gas, and propane in the 1985-1990 period. Electric heating using a heat pump would cost only moderately more than heating with one of these fuels in northern climates. Electric resistance heating, in spite of a lower forecast price growth rate for electricity than for oil and gas for home heating, is expected to cost from 50 percent to 100 percent more than these other options, at national average prices, in 1990. Large price differences are expected to continue to exist from region to region, however, so the fuel choice should reflect an analysis of price expectations at the regional level. Electric resistance heating appears likely to continue to be a reasonable option for space and DHW heat in areas with low electric rates.

In view of the above considerations, the following system selection process is recommended for space heating and DHW for new, energy-efficicnt residential buildings.

1. Plain fur a reasonable level of comfort under automatic control. The livuse should not require an excessive amount of interaction by occupants to maintain acceptable comfort.

2. Identify and define all air moving needs that should be considered for inclusion in the overall system design.

3. Estimate heating and cooling loads, using traditional methods of calculation such as ASHRAE procedures.

4. Identify the most appropriate heating and cooling distribution systems and ways of integrating the building's air moving needs with the distribution systems.

5. Assess fuels availability and projections of fuel and elertricity prices for the region and area of intelest.

6. Select the heating sources dud fucl, with consideration to new energy-efficient products and control strategies.

7. Select the DHW heat source, with consideration to integration of the DHW and space heatiuy systems. 
1. U.S. Department of Energy. Energy Performance Standards for New Bulldings, DOE/CS-0129, January 1980.

2. Lawrence Berkcley Laboratnry. Find and Fix the Leaks--A Guide to Air Infiltration Reduction and Indoor Air Quality Control, DOE/CE-UOU6, May 1981.

3. Hagan, D. A. Superinsulated Homes in North America--A Review and Update, paper presented to the ASME Solar Energy Division Fourth Annual Technical Conference, Albuquerque, NM, Apri1 26-30, 1982, BNL 30809.

4. Balcomb, J. D., et al. Passive Solar Design Handbook, Volume 2, Los Alamos Scientific Laboratory, DOE/CS-0127/2, January 1982.

5. Miller, R. L. Designs for Living, TWA Ambassador, April 1980, pp. 39-40.

6. Jones, R. F., Dennehy, G., Ghaffari, H. T., and Munson, G. E. Case Study of the Mastin Double Envelope House, May 1981, BNL 51460.

7. Dennehy, G. and Jones, R. F. Thermal Performance Analysis of a Double Envelope House, Proceedings of the Seventh National Passive Solar Conference, Knoxvil1e, Tennessee, August 30 -September 1, 1982.

8. Jones, R. F. and Dennehy, G. The Mastin Double Envelope House: A Thermal Performance Evaluation, Passive Solar Journal, Vo1. 1, No. 3, Summer 1982.

9. The Mother Earth News Shelter Special, Summer 1982.

1.0. Double-Shell Houses--At Last We Know Why They Work, Popular Science Monthly, February 1983.

11. DOE Energy Insider, April 28, 1980.

12. Private communication from Robert Sheehan, National Association of Home Builders, Washington, DC, March 7, 1983.

13. 1983 Statistical Panorama, The Air Conditioning, Heating and Refrigeration News, Apri $14,1983$.

14. National Association of Home Builders, Housing Backgrounder, February, 1983.

15. Joncs, R. W. (Editnr), Passive Solar Design Handbook, Volume 3: Passive Solar Design Analysis, Los Alamos National Laboratory, DUE/CS $=0127 / 3$, July 1982 .

16. Kroner, W. M. and Tichy, J. A. An Evaluation of Energy Flow Controls for Passive Heating and Cooling Systems, Center for Architectural Research, Rensselaer Polytechnic Institute, December 1978. 
17. ASHRAE Handbook: 1981 Fundamentals. American Society of Heating, Refrigerating and Air-Conditioning Engineers, Inc., 1981, New York.

18. Clark, W. W. (Editor), Propane Guide for Architects, Engineers and Builders, National LP-Gas Association, Arlington, Virginia, 1982.

19. U.S. Department of Energy. State Energy Price System, Volume I: Overview and Technical Documentation, DOE/NBB-0029, November 1982.

20. Gas Appliance Manufacturers Association. Directory of Certified Water Heater Efficiency Ratings, July 1982.

21. U.S. Department of Energy. Test Procedures for Water Heaters, Federal Register, page 54,112 , October 4, 1977.

22. Levins, W. P. Eetimated Seasonal Performance of a Heat Pump Water Heater Including Effects of Climate and In-House Location, ORNL/CON-81, January 1982 .

23. U.S. Department of Energy. Energy-Efficiency Directory of Oil Boilers, DOE/CS/20315-T12, August 1981.

24. U.S. Department of Energy. Energy-Efficiency Directory of Oil Furnaces, DOE/CS/20315-T13, August 1981.

25. U.S. Department of Energy. Energy-Efficiency Directory of Gas Boilers, DOE/CS/20315-T14, August 1981.

26. U.S. Department of Energy. Fnergy-Efficiency Directory ơf Gas Furnaces, DOE/CS/20315-T15, August 1981 .

27. Gas Appliance Manufacturers Assnciation. Dircctory of Cerlifled Firnace and Boiler Efficiency Ratings, October 1982 .

28. Asbury, J. G., et al. Residential Electric Heating and Cooling: Total Cost of Service. Argonne National Lahoratory, CONF-7809138, prepared for Sixth Annual Illinois Energy Conference on Elcctric Utilities In Illinois, Chicago, IL, September 27-29, 1978.

29. U.S. Department of Energy, Energy Information Administration. Residential Energy Consumption Survey: Hnusing Charactcristies, 1980. VUE/EIA-0314, June 1.982.

30. U.S. Departwent of Energy, Energy Information Administration, Natural Gas: Use and Expenditures, DOE/EIA-0382, Apri1 1983.

31. Vasilakis, A. D., et al, Research and Development of a High Efficiency Gas-Fired Water Heater, Volume 2, Task Reports. Advanced Mechanical Technology, Inc., Report No. ORNL/Sub-7381/2, January 1980.

32. Kohler, J., Wrap-up on Tankless Water Heaters, Solar Age, September 1982. 
33. Powe11, E., Tankless Water Heaters--New Way to Lower Your Energy. Bill, Popular Science Monthly, February 1982.

34. Heat Pump Water Heater (brochure), Oak Ridge National Laboratory, February 1981.

35. W. D'Allessandro, Which Solar Water Heater Should I Buy?, Solàr Age, March 1982.

36. U.S. Department of Energy, Introduction to Solar Heating and Cooling Design and Sizing, DOE/CS-0011, August 1978 .

37. Wilson, R. P., Caron, R. N., and Demetri, E. P., Demonstration of Integrated Gas-Fired Systems for Space Heating and Domestic Hot Water, June 1982 , BNL 51639.

38. ASHRAE Handbook: 1982 Applications. American Society of Heating, Refrigerating and Air-Conditioning Engineers, Inc., 1982, New York.

39. Petersen, S. R. and Kelly, G. E. An Economic Analysis of Efficlency Improvements to Residential Gas- and Oil-Fired Central Heating Equipment, NBSIR80-2079, National Bureau of Standards, July 1980.

40. Anderson, B. and We1ls, M., Passive Solar Energy, Andover, MA, Brick House Publishing Co., 1981 .

41. Rosenfeld, A. H. et al., Building Energy Use Compilation and Analysis (BECA), An International Comparison and Critical Review, Part A: New Residential Buildings, LBL-8912, November 1980.

42. Burch, D. M. and Tread, S. J., Ventilating Residences and Their Attics for Energy Conservation, Proceedings of Summer Attic and Whole-House Ventilation Workshop at National Bureau of Standards, Gaithersburg, Maryland, July 13, 1978.

43. Lunde, M. R. Optimizing the Wood Fuel/Residential HVAC System Interface. Paper presented at Solid Fuel Central Systems Symposium sponsored by Wood Energy Research Corporation, Cincinnati, OH, March 10-12, 1981.

44. Sheet Metal and Air Conditioning Contractors National Association. Fundamentals of Solar Heating, HCP/M4038-01 (Rev.), August 1978.

45. Kelley, M. and Slote, J., Design, Construction and Performance of a Low Cost, Remote Thermal Storage System, Proceedings of the Seventh National Passive Solar Conference, Knoxville, Tennessee, August 30 - September 1, 1982.

46. Reno, V. How to Size Up Solar Air Systems. Solar Age, January 1983. 
47. Abrams, D. W. Air Conditioning: System Sizing. Solar Age, January 1983.

48. U.S. Department of Energy, Energy Information Administration, 1982 Annual Energy Outlook, DOE/EIA-0382(82), April, 1983.

49. U.S. Department of Energy, Energy Information Administration, The Natural Gas Market Through 1990, DOE/EIA-0366, May 1983. 
APPENDIX

- $69-$ 
Table A-1

Unit Cost for Heating with Oil or Gas

(\$ por Million Btu of Useful Heat Delivered)

\begin{tabular}{|c|c|c|c|c|c|c|}
\hline \multirow{2}{*}{$\begin{array}{l}\text { Cas Price } \\
\text { (\$/CCF) }\end{array}$} & \multicolumn{5}{|c|}{ Annual Efficiency } & \multirow{2}{*}{$\begin{array}{l}\text { Oil Price } \\
\text { (\$/gallon) }\end{array}$} \\
\hline & $60-66 \%$ & $66-71 \%$ & $71-76 \%$ & $76-83 \%$ & $83-90 \%$ & \\
\hline$\$ .28-.30$ & $\$ 4.60$ & $\$ 4.23$ & $\$ 3.95$ & $\$ 3.63$ & $\$ 3.34$ & - \\
\hline $.31-.33$ & 5.08 & 4.67 & 4.35 & 4.00 & 3.68 & - \\
\hline $.34-.37$ & 5.63 & 5.18 & 4.83 & 4.44 & 4.08 & - \\
\hline $.38-.41$ & 6.27 & 5.77 & 5.37 & 4.94 & 4.54 & - \\
\hline $.42=.45$ & 6.90 & 6.35 & 5.92 & 5.44 & 5.00 & - \\
\hline $.46-.49$ & 7.54 & 6.93 & 6.46 & 5.94 & 5.47 & $\$ .63-.68$ \\
\hline $.50-.54$ & 8.25 & 7.59 & 7.08 & 6.50 & 5.98 & $.69-.75$ \\
\hline $.55-.59$ & 9.05 & 8.32 & 7.76 & 7.13 & 6.56 & $.76-.82$ \\
\hline $.60 \cdot .65$ & 9.92 & 9.12 & 8.50 & 7.81 & 7.18 & $.83-.90$ \\
\hline $.66-.71$ & 10.87 & 10.00 & 9.32 & 8.56 & 7.87 & $.91-.96$ \\
\hline $.71 \cdot .74$ & 11.51 & 10.58 & 9.86 & 9.06 & 8.33 & $.97-1.02$ \\
\hline $.75-.77$ & 12.06 & 11.10 & 10.34 & 9.50 & 8.74 & $1.03-1.07$ \\
\hline $.78-.81$ & 12.02 & 11.61 & 10.82 & 9.94 & 9.14 & $1.08-1.12$ \\
\hline $.82-.85$ & 13.25 & 12.19 & 11.36 & 10.44 & 9.60 & $1.13-1.18$ \\
\hline $86-.89$ & 13.89 & 12.77 & 11.91 & 10.94 & 10.n6 & $1.19-1.23$ \\
\hline $.90-.93$ & 14.52 & 13.36 & 12.45 & 11.44 & 10.52 & $1.24-1.29$ \\
\hline $.94-.97$ & 15.16 & 13.94 & 12.99 & 11.96 & 10,99 & $130=1.34$ \\
\hline $.98-101$ & 1.5 .79 & 14.53 & 13.54 & 12.44 & 11.44 & $1.35-1.40$ \\
\hline $1.02-1.05$ & 16.43 & 15.11 & 14.08 & 12.94 & 11.53 & $1.41-1.45$ \\
\hline $1.06-1.09$ & 17.06 & 15.69 & 14.63 & 13.44 & 12.36 & $1.46-1.50$ \\
\hline $1.10-1.12$ & 17.62 & 16.21 & 15.11 & 13.89 & 12.77 & $1.51-1.55$ \\
\hline $1.13-1.16$ & 18.17 & 16.72 & 15.58 & 14.32 & 13.17 & $1.56-1.60$ \\
\hline $1.17-1.19$ & 18.73 & 17.23 & 16.06 & 14.76 & 13.57 & $1.61-1.65$ \\
\hline $1.20-1.23$ & 19.28 & 17.74 & 16.53 & 15.19 & 13.97 & $1.66-1.70$ \\
\hline $1.24-1.27$ & 19.92 & 18.33 & 17.08 & 15.70 & 14.44 & $1.71-1.75$ \\
\hline $1.28-1.31$ & 20.55 & 18.91 & 17.62 & 16.19 & 14.97 & $1.76-1.81$ \\
\hline $1.32-1.35$ & 21.19 & 19.49 & 18.16 & 16.79 & 15.43 & $1.82-1.87$ \\
\hline $1.36-1.39$ & 21.83 & 20.07 & 18.71 & 17.30 & 15.90 & $1.88-1.92$ \\
\hline $1.40-1.43$ & 22.46 & 20.66 & 19.25 & 17.80 & 16.36 & $1.93-1.97$ \\
\hline $1.44-1.47$ & 23.09 & 21.24 & 19.80 & 18.30 & 16.82 & $1.98-2.03$ \\
\hline
\end{tabular}


Table A-2

Unit Cost for Electric Resistance Heating

( $\$$ per milition $B$ tu of useful heat delivered)

\begin{tabular}{|c|c|c|c|}
\hline $\begin{array}{c}\text { Cost of Electricity } \\
\$ / k W h\end{array}$ & $\$$ per million & $\begin{array}{c}\text { Cost of Electricity } \\
\$ / \mathrm{kWh}\end{array}$ & $\$$ per million \\
\hline $\begin{array}{l}.018-.019 \\
.020-.021 \\
.022-.024 \\
.025-.027 \\
.028-.030\end{array}$ & $\begin{array}{l}5.42 \\
6.01 \\
6.74 \\
7.62 \\
8.50\end{array}$ & $\begin{array}{l}.075-.079 \\
.080-.084 \\
.085-.089 \\
.090-.095 \\
.096-.02\end{array}$ & $\begin{array}{l}22.57 \\
24.03 \\
25.50 \\
27.11 \\
29.01\end{array}$ \\
\hline $\begin{array}{l}.031-.033 \\
.034-.037 \\
.038-.041 \\
.042-.045 \\
.046-.049\end{array}$ & $\begin{array}{r}9.38 \\
10.40 \\
11.58 \\
12.75 \\
13.92\end{array}$ & $\begin{array}{l}.103-.109 \\
.110-.119 \\
.120-.129 \\
.130-.139 \\
.140-.149\end{array}$ & $\begin{array}{l}31.07 \\
33.56 \\
36.49 \\
39.42 \\
42.35\end{array}$ \\
\hline $\begin{array}{l}.050-.054 \\
.055-.059 \\
.060-.064 \\
.065-.069 \\
.070-.074\end{array}$ & $\begin{array}{l}15.24 \\
16.71 \\
18.17 \\
19.64 \\
21.10\end{array}$ & $\begin{array}{l}.150-.159 \\
.160-.169 \\
.170=.179 \\
.180-.189 \\
.190-.199\end{array}$ & $\begin{array}{l}45.28 \\
48.21 \\
51.14 \\
54.07 \\
57.00\end{array}$ \\
\hline
\end{tabular}


Table A-3

Unit Cost for Heating with Electric Heat Pumps

( $\$$ per Million Btu of Useful Heat Delivered)

\begin{tabular}{|l|rrrrrr|}
\hline $\begin{array}{c}\text { Cost of } \\
\text { Electricity } \\
\text { (\$kWh) }\end{array}$ & \multicolumn{5}{|c|}{ Heating Season Performance Factor (HSPF) in Btu/Wh } \\
\cline { 2 - 7 } & $\mathbf{4 . 4 - 5 . 1}$ & $\mathbf{5 . 1 - 5 . 8}$ & $\mathbf{5 . 8 - 6 . 5}$ & $\mathbf{6 . 5 - 7 . 1}$ & $7.1-7.8$ & $7.8-8.5$ \\
\hline$\$ .018-.019$ & $\$ 3.87$ & $\$ 3.39$ & $\$ 3.01$ & $\$ 2.71$ & $\$ 2.46$ & $\$ 2.26$ \\
$.020-.021$ & 4.29 & 3.75 & 3.33 & 3.00 & 2.73 & 2.50 \\
$.022-.024$ & 4.81 & 4.21 & 3.74 & 3.37 & 3.06 & 2.81 \\
$.025-.117$ & 5.11 & 4.76 & 4.23 & 3.81 & 3.46 & 3.17 \\
$.028-.030$ & 6.06 & 5.31 & 4.72 & 4.24 & 3.86 & 3.54 \\
\hline $.031-.033$ & 6.69 & 5.85 & 5.20 & 4.68 & 4.26 & 3.90 \\
$.034-.037$ & 7.42 & 6.50 & 5.77 & 5.20 & 4.72 & 4.33 \\
$.038-.041$ & 8.26 & 7.23 & 6.42 & 5.78 & 5.26 & 4.82 \\
$.042-.045$ & 9.10 & 7.96 & 7.07 & 6.37 & 5.79 & 5.31 \\
$.046-.049$ & 9.93 & 8.69 & 7.73 & 6.95 & 6.32 & 5.79 \\
\hline $.050-.054$ & 10.87 & 9.51 & 8.46 & 7.61 & 6.91 & 6.34 \\
$.055-.059$ & 11.92 & 10.43 & 9.27 & 8.34 & 7.58 & 6.95 \\
$.060-.064$ & 12.96 & 11.34 & 10.08 & 9.07 & 8.25 & 7.56 \\
$.065-.069$ & 14.01 & 12.26 & 10.70 & 9.81 & 8.92 & 8.17 \\
$.070-.074$ & 15.05 & 13.17 & 11.71 & 10.54 & 9.58 & 8.78 \\
\hline $075-.079$ & 16.10 & 14.09 & 12.52 & 11.27 & 10.24 & 9.39 \\
$.080-.084$ & 17.14 & 15.00 & 13.33 & 12.00 & 10.91 & 10.00 \\
$.085-.089$ & 18.19 & 15.92 & 14.15 & 12.73 & 11.58 & 10.61 \\
$.090-.095$ & 19.34 & 16.92 & 15.14 & 13.54 & 12.30 & 11.28 \\
$.096-.102$ & 20.70 & 18.11 & .16 .10 & 14.49 & 13.17 & 12.01 \\
\hline $.103-.109$ & 22.16 & 19.39 & 17.24 & 15.51 & 14.10 & 12.92 \\
$.110-.119$ & 23.94 & 20.95 & 18.62 & 16.76 & 15.24 & 13.97 \\
$.120-.129$ & 26.03 & 22.78 & 20.25 & 18.22 & 16.56 & 15.18 \\
$.130-.139$ & 28.11 & 24.60 & 21.87 & 19.69 & 17.90 & 16.40 \\
$.140-.149$ & 30.21 & 26.44 & 23.50 & 21.15 & 19.23 & 17.63 \\
\hline
\end{tabular}

